\title{
IDENTIDADES INFANTIS CONTEMPORÂNEAS \\ TECNOLOGIAS DIGITAIS E OUTRAS FORMAS DE SER CRIANÇA E VIVER A INFÂNCIA
}




\section{IDENTIDADES INFANTIS CONTEMPORÂNEAS \\ TECNOLOGIAS DIGITAIS E OUTRAS FORMAS DE SER CRIANÇA E VIVER A INFÂNCIA}




\section{CONSELHO EDITORIAL}

Prof. Dr. Adilson Tadeu Basquerot e Silva

UNIDAVI/SC

http://lattes.cnpq.br/8318350738705473

Profa. Msc. Jesica Wendy Beltrán

UFCE- Colômbia

http://lattes.cnpq.br/0048679279914457

Profa. Dra Fabiane dos Santos Ramos UFSM- Santa Maria/RS

http://lattes.cnpq.br/0003382878348789

Dr. João Riél Manuel Nunes Vieira de

Oliveira Brito

UAL - Lisboa- Portugal.

http://lattes.cnpq.br/1347367542944960

Profa. Dra. Alessandra Regina Müller Germani

UFFS- Passo Fundo/RS

http://lattes.cnpq.br/7956662371295912

Prof. Dr. Everton Bandeira Martins

UFFS - Chapecó/SC

http://lattes.cnpq.br/9818548065077031

Prof. Dr. Erick Kader Callegaro Corrêa UFN- Santa Maria/RS

http://lattes.cnpq.br/2363988112549627

Prof. Dr. Pedro Henrique Witchs

UFES - Vitória/ES

http://lattes.cnpq.br/3913436849859138

Prof. Dr.Thiago Ribeiro Rafagnin UFOB

http://lattes.cnpq.br/3377502960363268
Prof. Dr. Mateus Henrique Köhler UFSM- Santa Maria/RS http://lattes.cnpq.br/5754140057757003

Profa. Dra. Liziany Müller Medeiros UFSM- Santa Maria/RS http://lattes.cnpq.br/1486004582806497

Prof. Dr. Camilo Darsie de Souza UNISC- Santa Cruz do Sul/RS http://lattes.cnpq.br/4407126331414

Prof. Dr. Dioni Paulo Pastorio UFRGS - Porto Alegre/RS http://lattes.cnpq.br/7823646075456872

Prof. Dr. Leonardo Bigolin Jantsch UFSM- Palmeira das Missões/RS http://lattes.cnpq.br/0639803965762459

Prof. Dr. Leandro Antônio dos Santos UFU- Uberlândia/MG http://lattes.cnpq.br/4649031713685124

Dr. Rafael Nogueira Furtado UFJF- Juiz de Fora/MG http://lattes.cnpq.br/9761786872182217

Profa. Dra. Angelita Zimmermann UFSM- Santa Maria/RS http://lattes.cnpq.br/7548796037921237

Profa. Dra. Francielle Benini Agne Tybusch

UFN - Santa Maria/RS http://lattes.cnpq.br/4400702817251869

Copyright (c) Arco Editora, alguns direitos reservados.

Copyright do texto (c) 2021 os autores e as autoras.

Copyright da edição (C) 2021 Arco Editora. 
Diagramação e Projeto Gráfico : Gabriel Eldereti Machado

Capa: elaborada por Vinícius Barbosa Cannavô e Tainá Suppi Pinto. Criada a partir da obra Meninos soltando pipas, Cândido Portinari, 1943.

Revisão: dos/as autores/as.

Dados Internacionais de Catalogação na Publicação (CIP) (Câmara Brasileira do Livro, SP, Brasil)

Identidades infantis contemporâneas [livro
eletrônico] : tecnologias digitais e outras
formas de ser criança e viver a infância /
organização Adilson Cristiano Habowski. --
Santa Maria, RS : Arco Editores, 2021.
PDF
ISBN 978-65-89949-24-4
1. Crianças 2. Cultura digital 3. Educação
infantil 4. Práticas midiáticas 5. Identidade
6. Infância - Aspecto social 7. Tecnologia
I. Habowski, Adilson Cristiano.
21-81973 CDD-306.432

Índices para catálogo sistemático:

1. Infância : Sociologia educacional 306.432

Maria Alice Ferreira - Bibliotecária - CRB-8/7964

\subsection{9/978-65-89949-24-4}

O padrão linguístico-gramatical, bem como o sistema de citações e referências bibliográficas são prerrogativas de cada autor. Da mesma maneira, o conteúdo e teor de cada capítulo é de inteira e exclusiva responsabilidade de seu respectivo autor. 
Talvez possamos pensar a educação de outra forma. Quiçá consigamos deixar de nos preocupar tanto em transformar as crianças em algo distinto do que são, para pensar se acaso não seria interessante uma escola que possibilitasse às crianças, mas também aos adultos, professoras, professores, gestores, orientadores, diretores, enfim, a quem seja, encontrar esses devires minoritários que não aspiram a imitar nada, a modelar nada, mas a interromper o que está dado e propiciar novos inícios. Quem sabe possamos encontrar um novo início para outra ontologia e outra política da infância naquela que já não busca normatizar o tipo ideal ao qual uma criança deva se conformar, ou o tipo de sociedade que uma criança tem que construir, mas que busca promover, desencadear, estimular nas crianças, e também em nós mesmos, essas intensidades criadoras, disruptoras, revolucionárias, que só podem surgir da abertura do espaço, no encontro entre o novo e o velho, entre uma criança e um adulto (KOHAN, Walter. Infância: entre educação e filosofia. 2005, p. 66). 


\section{SOBRE COMO SE ENGATINHA ATÉ A CABANINHA}

A criança enquanto sujeito e a infância enquanto marco temporal etário são datados e produzidos nas contingências de cada época, tornando-se objetos específicos de atenção no plano social, sobretudo da extensão do século das Luzes até o mundo contemporâneo.

O que é a criança? - Perguntaria um curioso despretensiosamente ou um moralista cheio de intenções outras.

Se houvessem respostas certas, não sei ao certo se essa coletânea precisaria ser escrita. Escrevemos, pois, como a criança, somos curiosos e não sabemos de tudo. Por isso perguntamos. O mundo é grande e complexo. Esquadrinhá-lo, sem a pretensão de apontar definições taxativas, é um espaço possível para a eclosão da diferença pela escrita. Neste âmbito, a escrita se torna uma ferramenta de intensidade que não revela as respostas certas [até porque é mais produtivo experimentar do que definir], mas pistas sendo construídas a cada lance de caneta no papel.

Mesmo sem definições objetivas, a criança é a inocência, o esquecimento, o jogo, a inventividade, a criação de novos mundos [e a destruição de todos eles], o desbravamento, o improvisar, uma ciranda, a queda, uma pulsão positiva sobre a vida, a descoberta, um movimento de dança, a experimentação, o fazer de conta, a fuga, os rabiscos de giz de cera na parede que outrora era branca, o cantarolar para afugentar o medo na escuridão.

Crianças não são arquivos de famílias nem esboços de adultos projetados pelas sociedades e seus regimes de verdade. Crianças não são plantinhas que, ao serem adubadas e regadas, meramente crescem como esperado. Crianças não são um ser outro promissor que encarna os valores que os adultos entendem como moralmente corretos. Não. É preciso libertar a criança das forças de controle estrito, que visam criar pretexto para civilizar a criança animalesca e as suas paixões. Paixões essas que são vistas em oposição a racionalidade e que, 
necessariamente, precisam ser domesticadas e convertidas em afetos entendidos socialmente como passíveis de operação em convenções sociais humanas.

O corpo da criança é um território em constante disputa almejado pelas forças dominantes que servem a norma vigente. Contudo, a criança é um corpo que resiste. $\mathrm{E}$ todo o corpo que resiste é um corpo que destrói para poder criar, de outro modo, diferente do anterior. A criança luta contra uma infinidade de forças que intentam capturar o seu corpo a partir das expectativas. Vai ser médico ou advogado? O importante é ser bem-sucedido. Você deve se casar, constituir família com uma pessoa do sexo oposto e ter filhos.

Qual a maneira adequada de cria-la [a criança]? - Diria o adulto.

A escola e a família reproduzem inaplicáveis modelos de princípios, valores e conhecimentos para as crianças, que apenas revelam a impotência permanente da relação entre escola e vida, tal como elas são atualmente. A criança não se encaixa nas normas e não se adequa as regras do jogo. Ela é esguia. Ela escorre. Ela escapa. Por não se adequar, ela brinca ao modo dela. Ela é flexível. Ela encontra a própria fenda e por ela engatinha, rasteja. Por isso, a criança não sabe dançar como o dançarino, mas ela dança em estado de êxtase, freneticamente, sem se preocupar com comentários e olhares outros para a sua performance.

Vamos brincar de cabaninha? Disse a criança.

A criança nasce quando o dever morre. Toda a criança é um devir. Com a morte da norma vigente e a ausência de preocupação com aquilo que os adultos esperam dela, ela vive de forma plena. Para a criança tudo é novo. Um caminho, uma trilha ou um itinerário pré-determinados? Não exatamente. Não há mapas a serem seguidos, não há guias marcando rotas, não há manuais que explicam como se deve ou não deve proceder diante das situações. A criança é aquela que cartografa passos rumo ao desconhecido, estabelecendo descaminhos a cada passo dado em sua exploração em busca de potências escondidas nas novas aventuras. 
Os escritos dessa coletânea precisam evocar a criança em estado de devir naqueles que leem ao passo que modifiquem os sujeitos que escrevem e experienciam a si mesmos pela relação entre o pensar e o escrever. É necessário que seja concedida uma oportunidade a criança que habita em cada um de nós. Criança essa que não sabe de tudo. Aquele que não sabe tudo, quem sabe, pode realizar as perguntas certas. Aprendamos com a criança e com o tempo de infância sem esquecer que: toda a parede em branco é uma tela de pintura.

Vinícius Barbosa Cannavô 


\section{SUMÁRIO}

\section{CAPÍTULO 1}

EDUCAÇÃO TRADICIONAL E O USO DA TECNOLOGIA NA INFÂNCIA GUARANI

Silvana Minduá Vidal Veríssimo

Antonella Tassinari

doi: 10.48209/978-65-89949-24-1

\section{CAPÍTULO 2}

A MINHOCA AGREDIDA E A ROSA DESPEDAÇADA: a naturalização do abuso e da violência contra a mulher nos discursos das canções infantis. .26

Eliana Cristina Pereira Santos

doi: 10.48209/978-65-89949-24-2

\section{CAPÍTULO 3}

A GERAÇÃO DIGITAL COMO IDENTIDADE CULTURAL NA CONTEMPORANEIDADE

Sandro Faccin Bortolazzo

doi: 10.48209/978-65-89949-24-3

\section{CAPÍTULO 4}

TECNOLOGIAS DIGITAIS E EDUCAÇÃO: DESENVOLVIMENTO DE JOGO PARA CRIANÇAS COM TRANSTORNO DO ESPECTRO DO AUTISMO.

Keila Aparecida Duarte Rufino

Vanessa Matos dos Santos

Valéria Peres Asnis

doi: 10.48209/978-65-89949-24-5 


\section{CAPÍtulO 5}

REFLEXÕES SOBRE O USO DAS TECNOLOGIAS NA INFÂNCIA.............78

Ana Angélica de Souza Alencar

Daniele Dorotéia Rocha da Silva Lima

Marcely Barroso Sarges

Joaquina lanca Miranda

doi: 10.48209/978-65-89949-24-6

\section{CAPÍtuLO 6}

PRÁTICAS DE ENSINO MULTIDISCIPLINARES NA EDUCAÇÃO

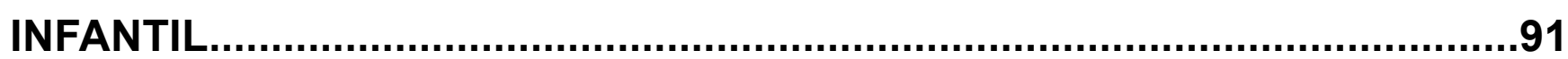

Renata Lourinho da Silva

Verena Cissa Barbosa de Castro Freitas

Gleide Cunha de Souza

Maria Nazare dos Prazeres Lopes

doi: 10.48209/978-65-89949-24-7

\section{CAPÍtuLO 7}

ALFABETIZAÇÃO DE CRIANÇAS COM NECESSIDADES EDUCATIVAS ESPECIAIS NA SALA DE RECURSOS: CONTRIBUIÇÕES DO USO DE PLATAFORMAS EDUCACIONAIS. 104

Claudinéia Garcia Ferreira de Oliveira

Maria Helena da Costa Bianchi

Maria Lucivane de Oliveira Morais

doi: 10.48209/978-65-89949-24-8

\section{CAPÍTULO 8}

CRIANÇAS E TECNOLOGIAS: REFLEXÕES A PARTIR DE CONTINGÊNCIAS EM TEMPOS DIGITAIS.

Adilson Cristiano Habowski

Vinícius Barbosa Cannavô

Tainá Suppi Pinto

doi: 10.48209/978-65-89949-24-9 
d $10.48209 / 978-65-89949-24-1$

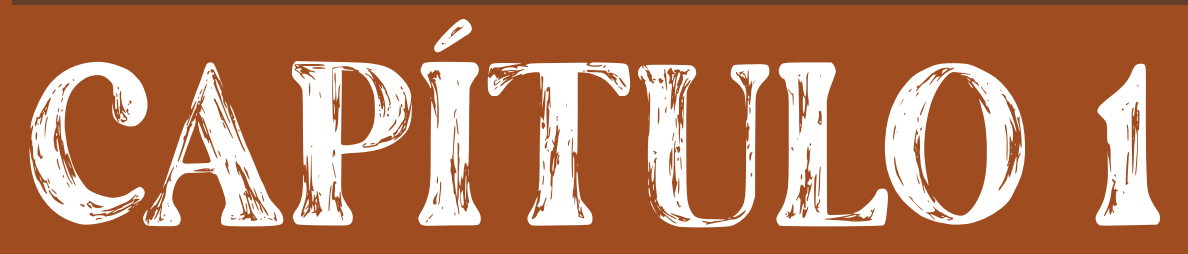

\section{EDUCAÇÃO TRADICIONAL EO USO DA TECNOLOGIA NA INEÂCIA GUARANI}

Silvana Minduá Vidal Veríssimo Antonella Tassinari 


\section{INTRODUÇÃO}

O uso de tecnologias, especialmente tablets e smartphones, tem exercido grande fascínio entre as crianças de todas as idades e isso não é diferente nas aldeias guarani de Santa Catarina, onde as crianças solicitam acesso aos equipamentos dos jovens e adultos para ouvir música e brincar com jogos eletrônicos. Quais as implicações disso para a continuidade dos modos tradicionais de educação guarani? O que as crianças têm aprendido com essas tecnologias? Este artigo pretende refletir sobre essas questões a partir da infância guarani na aldeia Mbiguaçu (SC), onde a autora Silvana Veríssimo atualmente reside. Trata-se de um texto escrito por uma autora guarani e uma autora não-indígena e, assim, procuramos respeitar nossas formas de escrever e argumentar. O trabalho é fruto de pesquisa desenvolvida no ano de 2019 por Veríssimo, com orientação de Tassinari, para elaboração da monografia de conclusão de curso na Licenciatura Intercultural Indígena do Sul da Mata Atlântica da UFSC (VERÍSSIMO 2020).

Com a perspectiva da Antropologia da Criança (COHN 2005) e atentas para a especificidade da infância indígena (TASSINARI 2007, 2009), abordaremos aspectos da infância e educação tradicional guarani, desde a gravidez até os cinco anos (momento antes das crianças frequentarem a escola), para pensar sobre o uso e influência da tecnologia. O objetivo maior do trabalho é valorizar a educação tradicional e reforçar os modos de vivenciar a infância guarani, refletindo sobre as fases de desenvolvimento e aprendizagem das crianças a partir do modo de ser guarani, também chamado de nhandereko (guarani falando, pois nhande é um termo usado por um falante guarani para falar "nosso" e reko significa um jeito de viver).

A partir das memórias de Veríssimo de sua infância e dos relatos obtidos em entrevistas com os pais, mães e avós da comunidade da aldeia Mbiguaçu (SC), buscamos compreender como era a experiência da infância nas gerações anteriores e as mudanças ou semelhanças que ainda existem nos modos de ensinar, aprender e interagir durante a infância guarani, especialmente considerando o acesso das crianças às novas tecnologias. Num primeiro item, vamos 
tratar dos modos guarani de compreender a infância em suas diferentes fases. Em seguida, abordaremos a atualidade da infância guarani na aldeia Mbiguaçu, em comparação com relatos dos mais antigos e com a memória da autora Veríssimo. Como conclusão, refletimos sobre as possibilidades das crianças guarani se beneficiarem do uso de tecnologias, sem perderem os vínculos com o nhandereko.

Figura 1: Crianças entretidas com joguinhos de celular, enquanto uma reunião de professores e alunos era realizada.

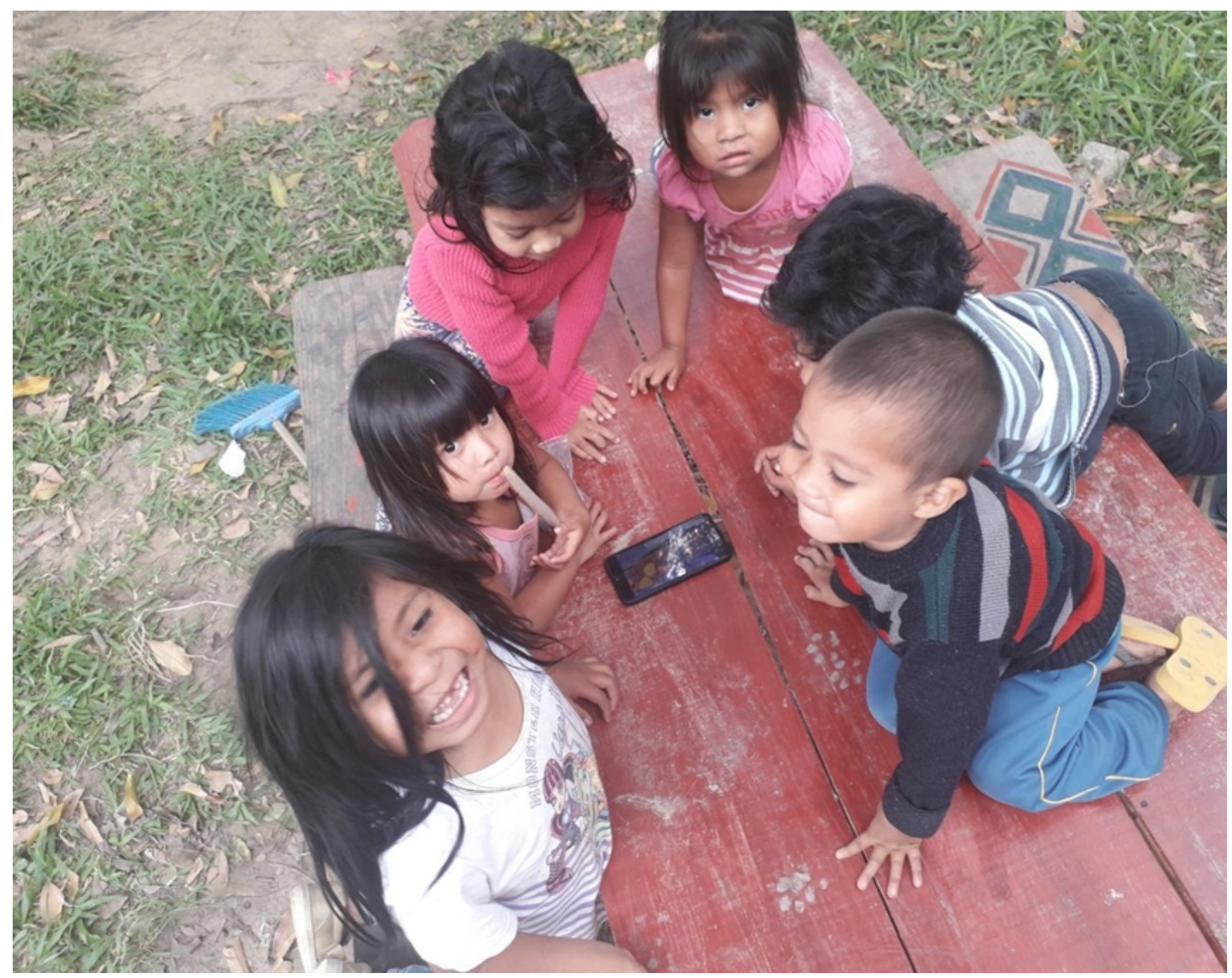

Foto: Veríssimo, 26/11/2019. Fonte: Veríssimo (2020).

\section{ASPECTOS E FASES DA INFÂNCIA GUARANI}

Os modos de ensinar e aprender durante a infância, para o povo guarani, estão relacionados ao sistema de vida que engloba o Nhandereko, o 
modo tradicional de viver, criar relações sociais na comunidade e com todas as coisas que existem ao nosso redor (pessoas, território, natureza, animais, Grande Espírito, etc.). Entende-se que essa educação é para o bem comum da comunidade, permitindo que a criança aprenda desde a fase inicial do crescimento, por sua própria iniciativa, a olhar, observar, interagir e acompanhar as outras pessoas no seu convívio diário. É importante saber que as crianças também farão parte no futuro da família, ou seja, de seu povo, da comunidade. Mas isso não quer dizer que sejam seres incompletos, como um vir-a-ser. As crianças são consideradas em sua plenitude como participantes da vida social, como têm apontado alguns trabalhos sobre infância indígena (COHN 2005, TASSINARI 2007).

No conceito das gerações anteriores e até hoje, dentro da cosmologia Guarani, as crianças são sagradas de alguma maneira e, por isso, são respeitadas pela família e por toda comunidade. Isso se relaciona às explicações guarani sobre o modo de ser e agir ou seja, o fundamento da pessoa humana, que reside no seu nhe'e, muitas vezes traduzidos por alma-palavra, que diz respeito à uma parte da pessoa proveniente das moradas divinas. Benites (2015, p.12-13) faz uma crítica a essa tradução e propõe falar em ser-nome ou espírito-nome para explicar o conceito guarani de nhe'e:

O nhe'ẽ é diferente, é um ser-nome que vem de Nhanderu kuery. Nhe'ẽ vem dos quatro amba: Karai Kuery, Jakaira, Nhamandu e Tupã Kuery. Nhe'ẽ, portanto, é o fundamento da pessoa Guarani e não palavra-alma, (...). Talvez uma tradução possível na língua portuguesa, por exemplo, e mais próximo do significado na língua guarani, seja espírito-nome. Entendo que alma e espírito (ambas de origem latina, a primeira vem de anima e a segunda de spiritus) em português são sinônimos, conforme o dicionário de Ferreira (2010). Mas, na língua guarani, como vimos, são termos completamente diferentes e de significados distintos. Inclusive, para nós Guarani, só depois que a criança começa a andar é que ela tem ã [alma], ou seja, ã é algo da terra, deste mundo. Quando lemos a tradução de nhe'ẽ como "palavra-alma" isso nos causa estranhamento.

Estranhamos não apenas algumas traduções feitas pelos jurua kuery, mas também a frieza do registro escrito. Quando os xamõi kuery nos falam sobre o nhe'ẽ, eles se emocionam. Porque nhe'ẽ está ligado ao sentimento, ao nosso py'a. Xamõi kuery oendu opy'are - eles sentem com o coração. 
Os adultos têm grande respeito às atividades das crianças, suas decisões e brincadeiras, pois são consideradas realizações do nhe'e, essa parte da pessoa que está conectada com as divindades. Considera-se que as crianças que nascem na comunidade guarani ou dentro do povo Guarani têm o privilégio de crescer no convívio diário com os pais, avós e todas as pessoas ao redor, sendo bem importante o papel dos pais de ensinarem seus filhos e repassar seus conhecimentos. Conforme o antropólogo guarani Davi Timóteo Martins (2015, p.53) explica:

Evidencia-se que a percepção e a vivencia de tais conhecimentos se dão nas atividades cotidianas em que, em meio de brincadeiras e responsabilidades, as crianças encontram companhia de outras, e relação entre pai, mãe, avos e tios, descobrindo, compartilhando e retransmitindo uns aos outros. Logo se percebe que toda a consequência e acontecimento que vem a acontecer com a fase adulta têm relação direta com o respeitar das regras na infância. Constrói-se na infância toda a fase aprendizagem e compreensão com o mundo, assim como nos cuidados da gestação, e dos pais.

Considerando que as noções de infância e desenvolvimento infantil não são universais, mas construídas em cada contexto sociocultural (COHN 2005) procuramos abaixo apontar algumas características da infância e dos seus diferentes períodos reconhecidos pelos guarani.

Segundo Veríssimo (2020, p.19) "Kyringue é o termo usado para criança (singular) e mitakuery para as crianças no plural ou na concepção de geral". Sendo o primeiro mais usado no Paraná e o segundo mais comum em Santa Catarina. A autora ressalta a importância de considerar o período da gestação como uma primeira fase da infância:

Ipuru'a régua- gravidez antes do nascimento, dentro do ventre da sua mãe, mas já é um ser com espírito preparando para o mundo. Quando falamos sobre nossas crianças e fazemos reflexão sobre o mundo dos nossos bebes, não poderíamos esquecer-nos de falar sobre a nossa gravidez, porque, antes de tudo com nossas crenças e religiosidade, a gravidez é um presente de Nhanderu Tenonde. O nosso Criador está acima de tudo, nós acreditamos que nos acolhe e cuida protege, nos ensina para ser bons com nosso próximo, dá toda sabedoria e conhecimento para que nós possamos viver em harmonia com tudo e todas que no rodeia. Então, é importante falar dos cuidados que mulher deve ter durante 
e processo da sua gravidez, porque acreditamos que um espírito de uma criança é puro, é ele que nos escolhe para vir ao mundo em que vivemos e já o consideramos um ser quando está dentro da barriga da mãe, que representa muito para nós também dentro nossa religião. Todos os cuidados são necessários para que a criança venha nascer com alegria e saúde para sua família (VERÍSSIMO, 2020, p. 20).

A ideia de que a vida intra-uterina é uma fase ativa da vida e um momento rico de aprendizagens vem recentemente sendo apontado em outros contextos culturais, como é o caso dos Karipuna, como demonstra o artigo de Tassinari (2021) sobre conhecimentos femininos sobre gestação, parto e puerpério. A autora menciona as contribuições de Christina Toren (2012) para pensar nessa fase da vida como um momento importante de interação do feto com o corpo da mãe, seus ritmos, movimentos e interações com o entorno, sendo, portanto, possível de ser analisada pela Antropologia.

Seguindo com a apresentação das características das fases da infância identificadas por Veríssimo (2020), temos: Oiko ramo i va-/mitã pytã (recém-nascido de $\mathbf{0}$ a 06 meses), sendo traduzido para o português por "vermelhinho" (pytã = vermelho e mitã $=$ criança $)$. Considerado um momento importante para o desenvolvimento da coordenação motora e também para o estabelecimento de relações afetivas com as pessoas mais próximas da família, além da sua mãe.

O período seguinte é chamado de Mitaguaxu va`e/kyrin guaxuokambu va'e (bebês, entre 6 meses e dois anos):

Fase em que os espíritos da criança que já estão aqui neste mundo que vivemos quando ainda precisa do colo e os cuidados da mãe e da família. Esta é a fase de construção social da comunicação, quando a criança está entre 06 meses a 02 anos; esta fase ainda de amamentação ainda precisa atenção e cuidados, mas já está na fase engatinhar e iniciando os primeiros passos para andar e tentar se comunicar com os adultos (VERÍSSIMO, 2020, p. 21).

Acredita-se que os bebês e crianças já vem com nomes, e quem consegue revela-los é o ancião (karaí), porque ele já tem toda preparação das rezas, ou seja, da cerimonia do nhemongaraí, momento importante no qual a criança 
recebe o nome. Isso normalmente acontece quando a criança está no desenvolvimento inicial de comunicação e da interação (quando a criança começa a engatinhar, quando está aprendendo os primeiros passos), principalmente com a mãe. Martins (2015) menciona a possibilidade de os nomes serem dados por outras crianças maiores que, durante as brincadeiras, falam os nomes das pequenas.

Kyringuaxu oguata va'e (crianças pequenas) é uma fase que vai dos 3 aos 5 anos, quando a criança aprende a brincar, interage e se comunica com pessoas de todas as idades. A brincadeira (nhevãga), que é uma característica central dessa fase, em alguns casos, é considerada sagrada, como também explica a antropóloga guarani Sandra Benites (2015). Algumas brincadeiras feitas espontaneamente pelas crianças são tomadas como presságios, pois, como elas estão conectadas aos deuses, suas brincadeiras podem ser indícios de que vai chover, que vai chegar uma visita, que a mãe vai engravidar ou que alguém vai adoecer, por exemplo. Por essa razão, os adultos respeitam muito esses momentos de brincadeiras e interação infantil.

Esse artigo tem como foco esses primeiros períodos da infância guarani. Após esse período, as demais fases da infância e da vida passam a ser diferenciadas também por gênero, conforme a autora Veríssimo $(2020$, p.22) explica em trabalho anterior:

Ava'i (masculino) e kunha'i (feminino). Crianças maiores. Mais ou menos entre 5 e 12 ou 13 anos. É uma fase que a criança tem mais autonomia, mas ainda tem restrições sobre as responsabilidades que pode assumir. Depende da força do seu corpo, se vai realizar certas atividades ou não. Também aprendem atividades e conhecimentos próprios de cada gênero. Aqui já começam a aprender sobre as mudanças que vão acontecer no seu corpo como menino ou menina.

Kunumi (masculino) e kunhatãi (feminino), quando as meninas e os meninos estão passando pelo processo da puberdade, podemos traduzir para adolescentes, mocinho e mocinha, respectivamente, idade que vai até aos 18 anos ou quando tem filhos.

Tuja hae (masculino) - vaimivae (feminino) - mulher e homem, quando se tornam ambos adultos, a partir dos 18 anos ou quando se tornam pessoas responsáveis, casam e/ou tem filhos e netos. As pessoas são assim chamadas até aproximadamente 60 anos.

Tuja'i va'e- velhinho vaimi'i va'e- velhina de 60 anos para cima. 
Na figura abaixo, vemos essas várias fases compondo o ciclo de vida guarani, entendido como um ciclo, pois implica num processo que tem continuidade e não como uma linha reta que vai de um ponto a outro.

Figura 2: Ciclo de vida Guarani

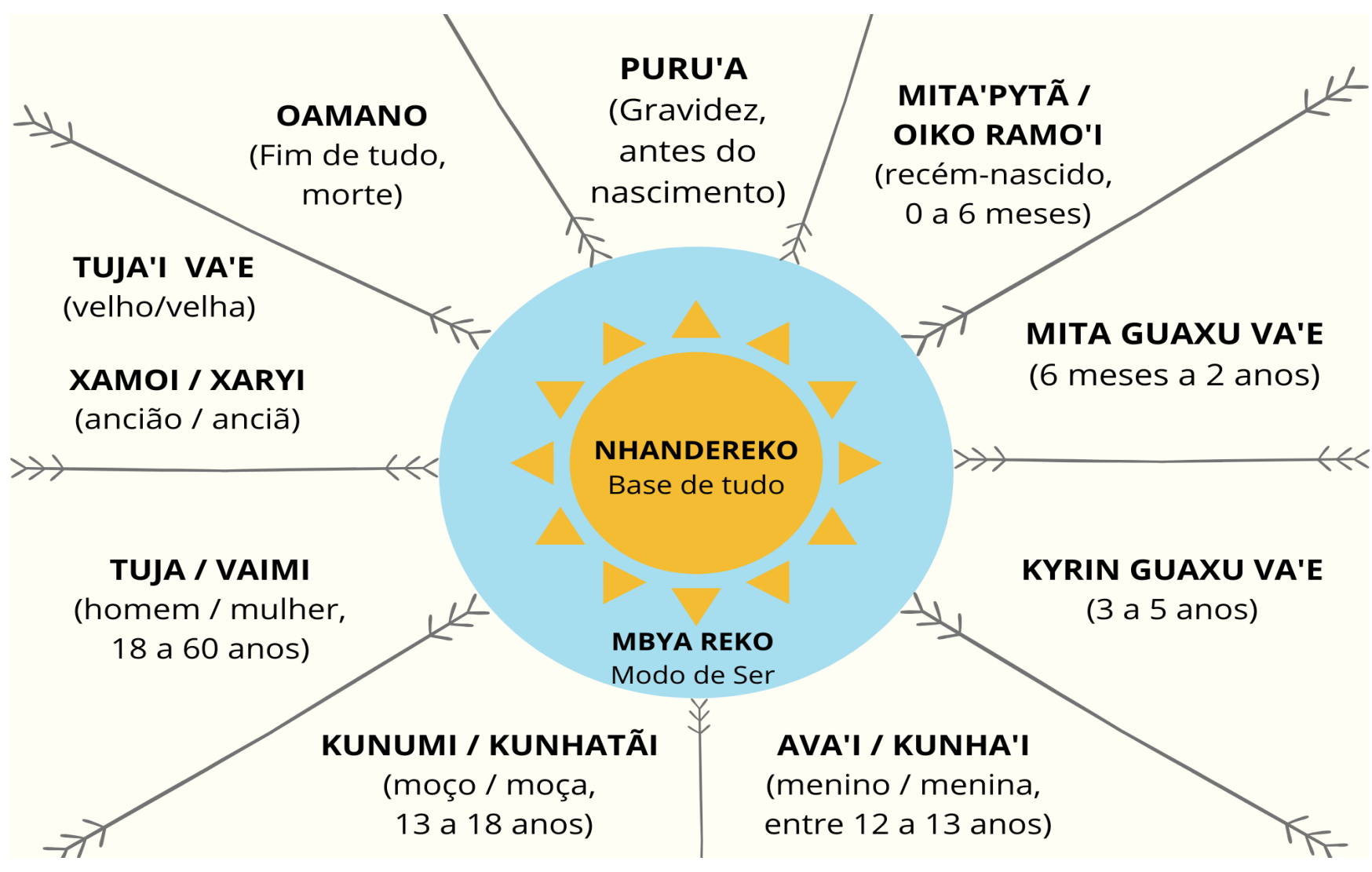

Fonte: Veríssimo (2020, p. 22): Elaborado pela autora e por Elis do Nascimento Silva.

\section{INFÂNCIA GUARANI NA ATUALIDADE EM COMPARAÇÃO COM O PASSADO}

A aldeia Mbiguaçu, também chamada Yyn Moroti Whera (Reflexo das águas cristalinas), foi delimitada em 1999 e homologada em 2003 (SALLES; PIERRI; CASTILLA; LADEIRA, 2015). Segundo Seu Alcindo Whera Tupã, ancião centenário e liderança espiritual da comunidade, a presença guarani na região é muito antiga.

Desde quando seu Alcindo era criança, ele conta que já passava por esse local que era um lugar de descanso, mas que ficava um bom tempo, de acordo com a sua história que há mais de quatro gerações do povo Guarani que já moraram nessa aldeia. Com a construção estrada asfalto BR que passa no meio da aldeia, foi demarcado 59 hectares, nos quais 
atualmente vivem 38 famílias com 150 de pessoas (VERÍSSIMO, 2020, p. 28).

Na memória das pessoas entrevistadas por Veríssimo e nas suas próprias lembranças, a infância guarani era um período de conexões com outras crianças, adultos e com o ambiente, através de brincadeiras e da participação nas atividades dos pais. Essas lembranças se referem à pequena infância (Kyringuaxu oguata va'e), quando as crianças já aprenderam a falar e já estabeleceram os vínculos com sua família extensa e, então, passam a fazer conexões com as outras pessoas da aldeia, sempre guiadas por pessoas da sua família.

No tempo de minha avó e de meu pai, o modo de vida era bem diferente do que é hoje, muito ligado ao tempo da natureza. Assim que o sol se punha e escurecia, todos se recolhiam para as casas. Minha avó tinha costume de dormir cedo e acordar cedo, ela não usava relógio, como todos da família, meus tios, tias, meus pais, mas como a maior parte da minha infância foi com minha avó, eu também tinha costume de dormir cedo. Antes, a minha avó gostava de contar um conto ou uma história, uma coisa interessante que, contudo, quando ela terminava de contar sempre tinha alguma reflexão ou uma lição de moral no final da história (VERÍSSIMO, 2020, p.24).

Esses momentos preciosos de interação com os mais velhos, de ouvir histórias, aprender lições de moral, sempre foram também momentos importantes para bebês e crianças pequenas aprenderem a língua guarani, que até hoje é a primeira língua aprendida pelas crianças.

No dia a dia, as crianças sempre estiveram próximas dos pais, acompanhando seus movimentos e atividades e aprendendo com isso. Se os pais vão à roça ou à casa de rezas, chamada de opy, as crianças os acompanham e assim vão aprendendo sobre plantas, animais, objetos sagrados, instrumentos musicais. Aprendem a rezar na opy, através de cantos e danças. Sua participação ali é considerada fundamental, já que são consideradas mais próximas dos deuses, pois seus nhe'e ainda estão conectados com as moradas divinas. Não estão lá somente para aprender, mas também para entoar seu canto e suas belas palavras para o benefício de todos.

Atualmente, na comunidade, cada família tem sua moradia e um quintal para plantio, mas são também desenvolvidas atividades coletivas. Entre estas 
atividades, está a limpeza da aldeia, os cuidados com a horta e a lavoura comunitária. São eventos importantes para unir as famílias na responsabilidade e orientação das crianças. Há também na aldeia alguns funcionários públicos, como professores, dois agentes de saúde e um agente de saneamento básico. $\mathrm{Na}$ aldeia, também há vários artesãos que auxiliam, com suas práticas, a renda familiar. Com a necessidade de trabalhos assalariados para a complementação da renda, as pessoas ficaram cada vez mais atreladas a uma temporalidade regida pelo relógio e não mais pelo ambiente.

Nas gerações anteriores, as crianças brincavam entre si, mas não deixavam de olhar o que as mães estavam fazendo, limpando ou plantando a roça, algumas das crianças tinham a curiosidade de pegar as ferramentas, tocar nas plantas, na terra, até mesmo ajudar a mãe em sua atividade na roça. Hoje em dia, as mães têm também outras atividades, que incluem computadores e telefones celulares. É normal as famílias terem em casa os aparelhos eletrônicos como TVs, celulares, entre outros.

Figura 3: Num sábado pela manhã, perto da estufa das hortaliças, as crianças estavam brincando perto da mãe que capinava o terreno. Observamos a importância da socialização, da brincadeira entre as crianças e o respeito dos adultos diante desse evento.

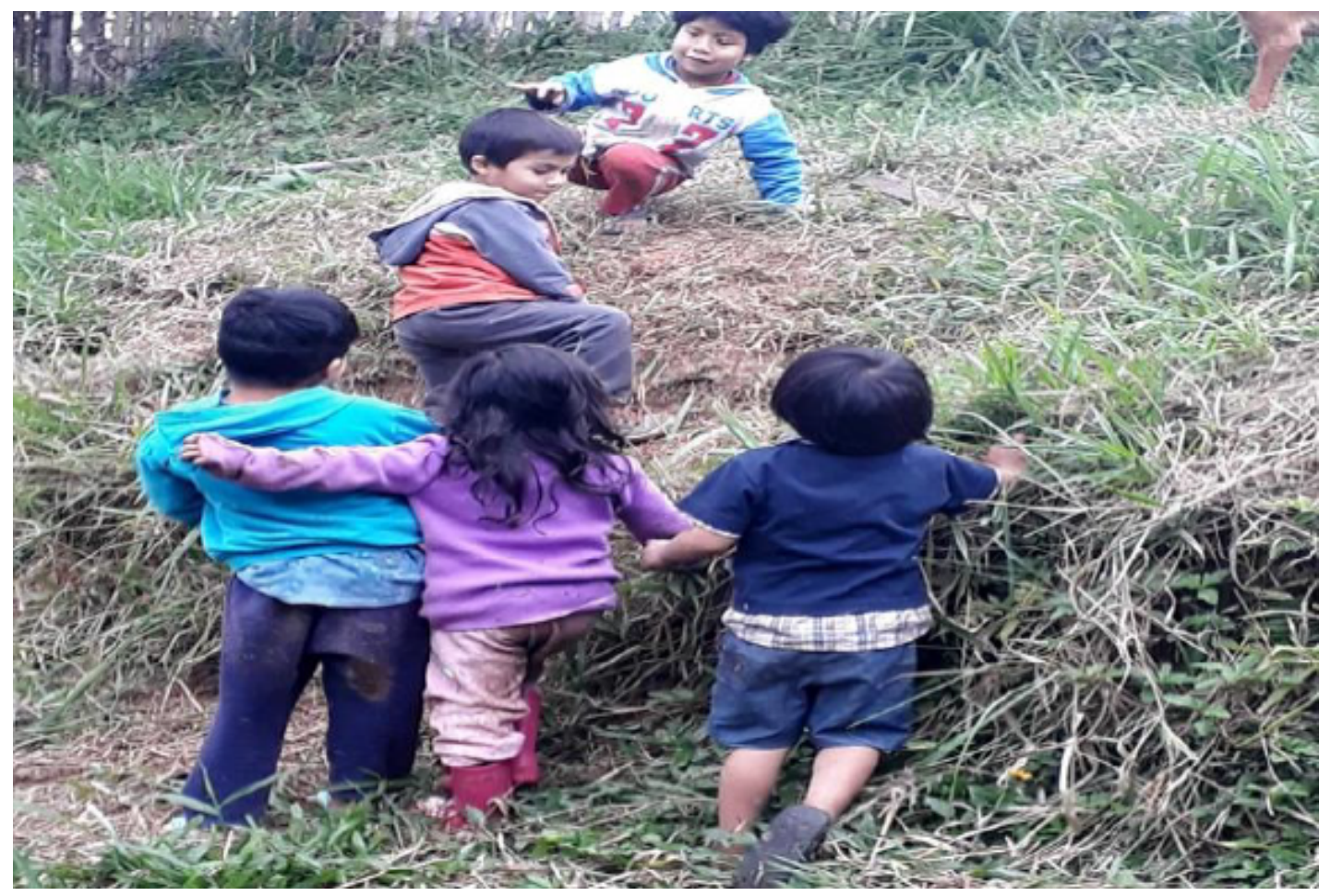

Foto: Veríssimo, março, 2018. Fonte: Veríssimo (2020). 
Figuras 4 e 5: Enzo, filho da autora Veríssimo, auxilia a avó na horta. Gesto dos mais velhos é repetido pelos mais novos. Aprendizado compartilhado.

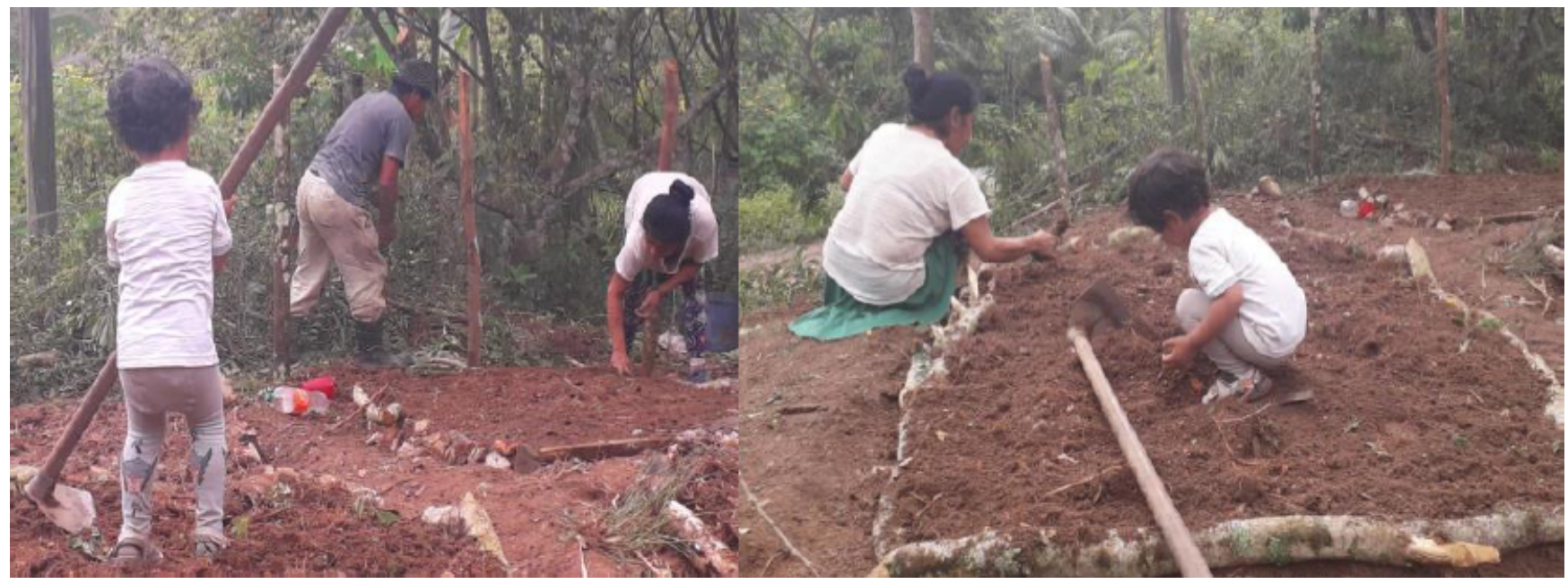

Foto: Veríssimo, novembro/2019. Fonte: Veríssimo (2020).

Figura 6: As crianças podem acompanhar seus pais à Opy (casa de reza) para participar de atividades, mas não são obrigadas. Nessa imagem, elas brincam enquanto os pais participam da cerimônia na Opy.

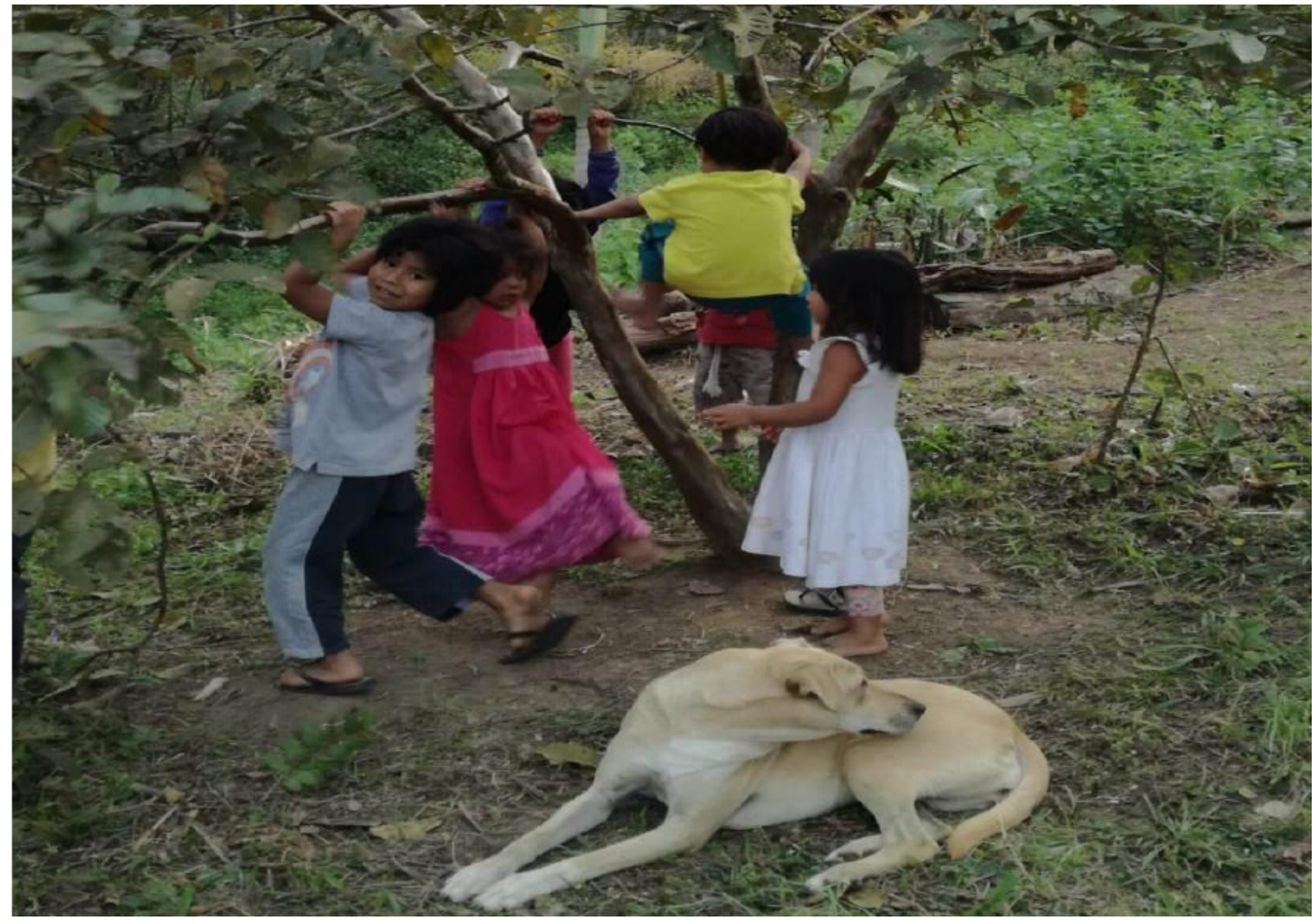

Foto: acervo da comunidade, 2018. Fonte: Veríssimo (2020). 
Pela observação de Veríssimo (2020), a presença de equipamentos tecnológicos não é o único fator a alterar a experiência da infância na atualidade, mas também o fato de mães, pais e avós não estarem mais tão disponíveis, pelas exigências ligadas a outras formas de trabalho. Assim, os tablets e smartphones acabam substituindo as conexões que as crianças tinham antes com seus familiares, tanto adultos quanto crianças. Os pais e avós não têm tido mais tempo para contar histórias no final do dia. Às vezes, esses momentos são substituídos pela televisão. O costume de deitar-se e acordar-se cedo vem sendo também modificado, tanto pelos adultos quanto pelas crianças.

Veríssimo (2020) observou que crianças a partir de um ano, que antes falavam somente a língua guarani, atualmente já conhecem várias palavras em português, aprendidas por meio das novas tecnologias. No que se refere às brincadeiras com outras crianças, percebe-se também uma tendência a ficarem mais isoladas quando estão com celulares, diferente das brincadeiras que implicam em interações, quando estão brincando nas roças.

Figura 7: Mesmo com outros brinquedos disponíveis, o aparelho celular chama muita atenção das crianças.

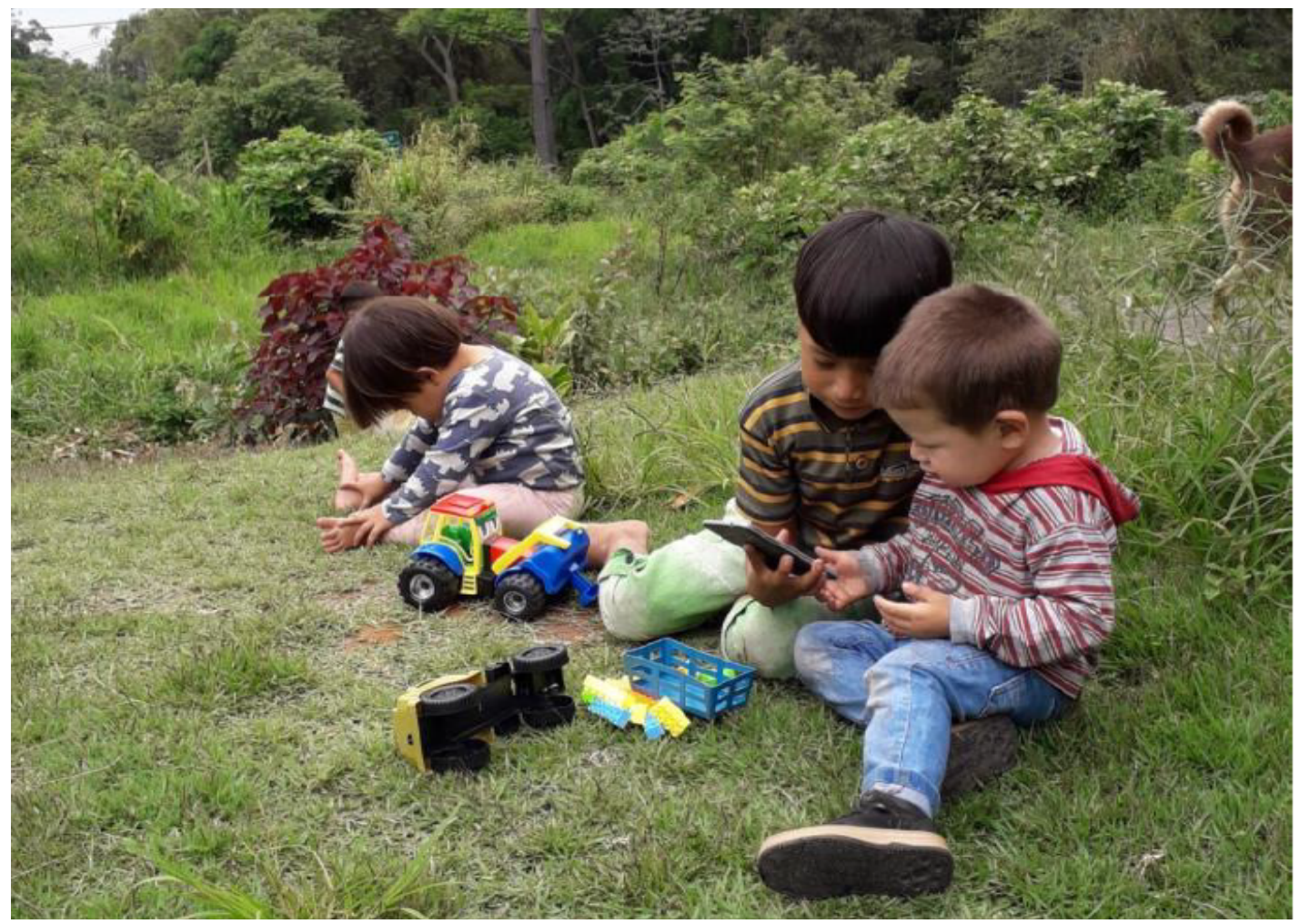

Foto: da autora, outubro e novembro de 2019. Fonte: Veríssimo (2020). 
As figuras 3 a 6 mostram, no entanto, que essa tendência ao isolamento motivada pelas novas tecnologias não tem substituído totalmente a participação das crianças em atividades da família e o vínculo lúdico com outras crianças.

\section{CONSIDERAÇÕES FINAIS}

Neste artigo procuramos refletir sobre alguns desafios para a manutenção do modo de vida tradicional guarani, nhandereko, a partir da presença de novas tecnologias nas aldeias. Um exemplo desses desafios é a introdução da língua portuguesa como segunda língua, sem o acompanhamento dos adultos, que se preocupam com os valores que as crianças possam estar aprendendo nesse processo. Outro exemplo é uma tendência ao isolamento das crianças que estão envolvidas com celulares e deixam de lado a companhia de outras crianças e familiares.

Procuramos argumentar que esses desafios não decorrem somente do uso de tecnologias, mas também das novas exigências dos trabalhos realizados pelos adultos, que as crianças nem sempre podem acompanhar (especialmente no que se refere a trabalhos assalariados). Assim, a falta de conexão com os adultos e as atividades que estão realizando é um fator importante para entender a motivação das crianças com essas novas tecnologias.

Segundo Veríssimo (2020), há muito tempo essas questões têm preocupado os educadores e orientadores da comunidade que são os anciãos, acostumados a transmitir valores e conhecimentos através da oralidade, tiveram que se se adaptar a uma nova tecnologia que foi a escrita. A própria escolarização é muito recente entre os guarani de Santa Catarina, como narra Oliveira (2002). A escola começou a ser construída em 1996 e Mbiguaçu foi a primeira aldeia guarani do litoral catarinense a aceitar o ensino escolar.

Mas, se atualmente, a escola já é parte do cotidiano das crianças e é considerada um importante espaço de ensino de conhecimentos indígenas e não-in- 
dígenas, por que não tirar também benefícios das novas tecnologias?

Infelizmente, não dá para voltar a viver uma infância igual ao passado, os conhecimentos e tecnologias dos juruá estão impostos dentro da comunidade. Porque não adaptar? E usar essas novas ferramentas, como mecanismos de passar conhecimento, que nos favorece em método de ensino na comunidade, na fase de acompanhamento da vida diária das crianças na aldeia, na casa, durante as atividades coletivas, em alguns episódios quando acontece evento grande na comunidade (VERÍSSIMO, 2020, p.36).

Com essa perspectiva, Veríssimo propôs em sua monografia um projeto de criação de um espaço de convivência para as crianças, onde possam interagir entre si, com anciões e com o ambiente, tentando reproduzir as vivências da infância das gerações anteriores. Em relação às novas tecnologias, a ideia não é restringir o seu uso, mas tentar ter equilíbrio, utilizando o seu potencial como instrumentos de registros da vida da aldeia e propiciando ocasiões de maior conexão com outras crianças.

\section{REFERENCIAS}

BENITES, Sandra. Nhe'ẽ, reko porã rã: nhemboea oexakarẽ. Fundamento da pessoa guarani, nosso bem-estar futuro (educação tradicional): o olhar distorcido da escola. Trabalho de Conclusão de Curso Licenciatura Intercultural Indígena do Sul da Mata Atlântica. Florianópolis: UFSC. 2015.

COHN, Clarice. Antropologia da Criança. São Paulo: Jorge Zahar. 2005.

MARTINS, Davi Timóteo. Kyringuei'Kuery: noções nativas de infância, aprendizagem e desenvolvimento da pessoa. Trabalho de Conclusão de Curso Licenciatura Intercultural Indígena do Sul da Mata Atlântica. Florianópolis: UFSC. 2015.

OLIVEIRA, Melissa Santana. Reflexos das águas cristalinas: um estudo sobre a presença da escola yynn moroti whera na aldeia Guarani Mbiguaçu, Grande Florianópolis - SC. Trabalho de Conclusão de Curso de Graduação em Ciências Sociais. Universidade Federal de Santa Catarina, Florianópolis, 2002. 
SALLES, C.; PIERRI, D.; CASTILLA, E.; LADEIRA, M. (org.). Atlas das Terras Guarani no Sul e Sudeste do Brasil. Centro de Trabalho Indigenista - CTI, 2015.

TASSINARI, Antonella. Concepções indígenas de infância no Brasil. Revista Tellus, Campo Grande, v. 7, n. 13, p. 11-25, 2007.

TASSINARI, Antonella. Múltiplas Infâncias: o que a criança indígena pode ensinar para quem já foi à escola ou A Sociedade contra a Escola, comunicação apresentada no $33^{\circ}$ Encontro da ANPOCS. 2009.

TASSINARI, Antonella. A "mãe do corpo": conhecimentos das mulheres Karipuna e Galibi-Marworno sobre gestação, parto e puerpério. Horizontes Antropológicos, Porto Alegre, ano 27, n.60, p.95-126. 2021.

TOREN, Christina. Antropologia e Psicologia. Revista Brasileira de Ciências Sociais, Vol. 27, $n^{\circ}$ 80. 2012.

VERÍSSIMO, Silvana Minduá. Educação tradicional e o uso da tecnologia na infância Guarani / Kyringue Onheovanga Ha' e Jurua Mba' e Oiporu Onhembo' ea Py. 2020. Trabalho de Conclusão de Curso (Licenciatura Intercultural Indígena do Sul da Mata Atlântica) - Centro de Filosofia e Ciências Humanas, Universidade Federal de Santa Catarina, Florianópolis, 2020. 
doi $10.48209 / 978-65-89949-24-2$

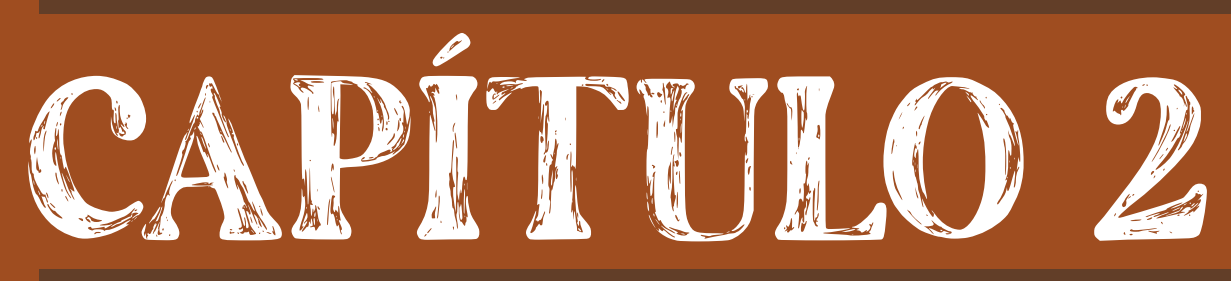

\section{A MINHOCA AGREDIDA E A} ROSA DESPEDAÇADA: A NATURALIAACỸ̃O DO ABUSO E DA VIOLÊTCIA CONTRA A MULFIER NOS DISCURSOS DAS CANÇÖES INEANTHS

Eliana Cristina Pereira Santos 
RESUMO: Na Teoria do Discurso de matriz pecheutiana, não são defendidas teorias inatistas. A linguagem não é questão de hereditariedade: é algo a ser aprendido. A linguagem não é só lógica ou biológica e, por isso, não se podem ignorar as problemáticas patológicas, históricas e culturais que ela apresenta. Entretanto, somos sujeitos da/na linguagem, atravessados pelo inconsciente. Sendo assim, neste trabalho buscamos analisar alguns discursos que, na sua fragmentação, circulam nas cantigas infantis, reorganizando as práticas sociais desde tenra idade. Cantigas que ecoam, ressoam na história, impondo maneiras de comportamento nas crianças, segmentando binariamente o masculino e o feminino. Uma memória social que estrutura, reestabelece e também representa a realidade e seu campo de forças das relações sociais para mudança ou sua conservação. A minhoca, a rosa, o minhoco e o cravo discursivizando sentidos de práticas sociais.

PALAVRAS-CHAVE: Discurso. Feminino. Cantigas infantis.

\section{LA LOMBRIZ ATACADA Y LA ROSA DESMEMBRADA: la naturalización del abuso y la violencia contra las mujeres en los discursos de las canciones infantiles}

RESUMEN: En la matriz pecheutiana de la Teoría del Discurso no se defienden las teorías innatistas. El lenguaje no es una cuestión de herencia: es algo que se aprende. El lenguaje no es sólo lógico o biológico y, por tanto, no se pueden ignorar los problemas patológicos, históricos y culturales que presenta. Sin embargo, somos sujetos de/en el lenguaje, atravesados por el inconsciente. Así, en este trabajo pretendemos analizar algunos discursos que, en su fragmentación, circulan en las canciones infantiles, reorganizando las prácticas sociales desde una edad temprana. Canciones que resuenan, que resuenan en la historia, que imponen formas de comportamiento a los niños, que segmentan binariamente lo masculino y lo femenino. Una memoria social que estructura, restablece y también representa la realidad y su campo de fuerza de relaciones sociales para el cambio o su conservación. El gusano, la rosa, la lombriz y el clavel discursivizando significados de las prácticas sociales.

PALABRAS CLAVE: Discurso. Femenino. Canciones para niños. 


\section{THE BEATEN WORM AND THE SHATTERED ROSE: the naturalization of abuse and violence against women in chil- dren's song speeches}

SUMMARY: In Pecheutian Matrix Discourse Theory, innate theories are not defended. Language is not a matter of heredity: it is something to be learned. Language is not only logical or biological and, therefore, one cannot ignore the pathological, historical and cultural problems it presents. However, we are subjects of/ in language, crossed by the unconscious. Thus, in this work we seek to analyze some discourses that, in their fragmentation, circulate in children's songs, reorganizing social practices from an early age. Songs that echo, resonate in history, imposing ways of behavior on children, segmenting the male and female binary. A social memory that structures, reestablishes and also represents the reality and its force field of social relations for change or its conservation. The worm, the rose, the worm and the harpsichord discursive meanings of social practices.

KEY WORDS: Discourse. Feminine. Children's songs.

\section{INTRODUZINDO...}

Se não ressoar se não ecoar na história não cola não permanece.

(Pêcheux)

Com a epígrafe do ressoar não há como não pensar que somos resultado de uma junção de discursos que nos definem por meio da linguagem. Somos sujeitos de linguagem: todas as coisas que estão ao nosso redor têm um nome, alguns são nomes próprios, outros são apenas comuns. Fato que é a linguagem que nos atravessa e nos constitui em sujeitos sociais. Inicialmente, é preciso entender como se dá o processo de entrada do sujeito na linguagem. Esse processo, realizado pela fala e pelas canções, favorece o aprendizado das crianças. Mas quais são as músicas que os pequenos vêm cantando? Quais são os discursos dessas canções? 
Neste trabalho, buscamos compreender a produção do discurso por meio das materialidades discursivas presentes nas canções infantis. Materialidades que se (re)organizam para fazer funcionar enquanto discurso. Se entendermos que a linguagem está em curso, por ser histórica, viva, os sentidos sobre as coisas também estão fixos, muito menos são universalizantes, na medida em que a língua não é apenas um sistema. É justamente o contrário, não há uma homogenia discursiva, não há um único sentido, há, pois, efeitos de sentidos, visto que se trata de uma "superfície de cada discurso às superfícies possíveis que the são (em parte) justapostas na operação de análise, constituem justamente os sintomas pertinentes do processo de produção dominante que rege o discurso submetido à análise" (PÊCHEUX, 1993, p. 105).

Entretanto, mesmo que sejam superfícies aparentemente diferentes no intradiscurso, há um dominante que rege esses sintomas que é "o interdiscurso, que [...] põe em conexão entre si elementos discursivos por meio do pré-construído" (PÊCHEUX, 2009, 154), produzindo um efeito de sustentação dos saberes de uma formação discursiva. E nessa ordem de pré-construído e da repetição vem reestabelecer, por meio da memória discursiva, "a condição legível do próprio legível" (PÊCHEUX, 2007, p. 52). E mais, sob a forma dos versos das canções, discurso estável e sedimentado, "a formação de um efeito de série pelo qual uma regularização [...] residiriam os implícitos" (PÊCHEUX, 2007, p. 52), os efeitos de opacidade, o conjunto de marcas da existência material do discurso.

Dessa maneira, buscaremos investigar duas canções do universo infantil brasileiro, para analisar e exemplificar versos cantados de formação discursiva dominante em que se inscrevem enquanto efeitos de sentidos. Cantigas que ecoam, ressoam na história, maneiras de comportamento nas crianças, segmentando binariamente o masculino e o feminino, que são da ordem da memória social. Uma memória social que estrutura, reestabelece e também representa a realidade e seu campo de forças das relações sociais para sua mudança ou sua conservação. 
O texto será dividido em mais três partes: conceitos em relação às canções, a música, as sequências discursivas a serem analisadas e considerações finais, que abrem um leque para que mais pesquisadores possam acrescentar novas discussões.

\section{MÚSICA E CRIANÇA: conceitos essenciais}

A música faz parte da vida das pessoas desde o nascer, quando estas são expostas às canções de ninar, à canção que a família gosta, condições que, aos poucos, vão ampliando a relação da criança com a música. Cantigas, canções de roda, brincadeiras musicalizadas contribuem para universo de simbolização do mundo. Para além do conceito de música, buscamos a importância da musicalização na infância. Como atividades lúdicas, as músicas são apresentadas "à criança por meio de canções [...] danças, exercícios de movimento, relaxamento e prática em pequenos conjuntos instrumentais" (BRITO, 2003, p. 45). As crianças, depois da aquisição das primeiras palavras, são introduzidas à sistematicidade da vida social por meio de algumas músicas.

Nas escolas brasileiras, a música integra as atividades lúdicas. Entretanto, somente a partir da Lei $n^{\circ}$ 11. 769/2008 - que alterou a Lei n 9.394/1996 (Lei de Diretrizes e Bases da Educação), para dispor sobre a obrigatoriedade do ensino da música na educação básica - e da Lei n 13.278/2016 (que alterou a LDB para fixar as diretrizes e bases para o ensino da arte), é que a música enquanto linguagem ganhou status de obrigatoriedade nos currículos escolares.

Assim, desde tenra idade as crianças escolarizadas possuem uma rotina de cantar canções consideradas 'de criança': com versos curtos, rimas fáceis, repetitivas e muitas com uma pitada de humor. Fato é que as canções nos rodeiam desde a tenra idade e não há nenhum problema com a musicalização, pelo contrário: é essencial para nossa relação com a sociedade. As canções, como formas culturais e estéticas, não podem ser encaradas apenas com uma simples troca cultural, uma vez que discursivizam sentidos. Em seus enunciados 
cantados, há existência do simbólico, repetido pela melodia, pelo ritmo, porque é cultural.

Retomando, somos sujeitos da história constituídos e atravessados pela linguagem e pelo inconsciente. Para Lacan (1988), o sujeito se identifica na linguagem e é inserido no campo de significantes do Outro, "mas somente para perder-se nela como objeto" (LACAN, 1988, p. 301), ou seja, pela via do inconsciente somos inscritos na linguagem, e por ela existimos e significamos. São os pais ou responsáveis que inscrevem essa criança na linguagem, primeiramente falada: a fala é a materialização dessa inscrição. Muito próximo aos estudos vigotskianos, que enfatizam a necessidade de o sócio-histórico anteceder o caráter inato. Nas palavras de De Lemos (2002, p. 55), "conceber a criança como capturada por um funcionamento linguístico discursivo que não só a significa como lhe permite significar outra coisa, para além do que a significou". Em outras palavras, ela é significada, em significante, e essa sua significação lhe permite ressignificar a partir dessa do que the significou. Lembrando que para a psicanálise, o significante não tem sentido em si, ele opera em uma cadeia de significantes. Por isso, o sujeito é clivado, dividido, atravessado pelo inconsciente e pela ideologia.

Para tal, se faz necessário compreender qual é o sujeito da análise de discurso, além de social, histórico e ideológico, é também clivado pelo inconsciente. Para a teoria do discurso, "o discurso de um outro, coloca em cena pelo sujeito [...] mas também e sobretudo a insistência de um 'além' interdiscursivo que vem, aquém de todo autocontrole funcional do 'ego-eu'” (PÊCHEUX, 1993, p. 316). Esse sujeito/criança, que é assujeitado, de uma posição-sujeito emerge no discurso das canções metaforizadas em animais falantes, flores, etc., inscrevendo a linguagem na história e nas condições sociais em que vivem. Neste processo, os efeitos de sentido inscritos nessas cantigas ganham a dimensão simbólica.

Dito de maneira simplificada, a criança é introduzida na linguagem (Outro) pelo outro que pode ser os pais. A partir daí, começa a acessar como as coisas significam, funcionam, acessa a realidade por meio do simbólico. Diante disso 
passaremos às análises de canções simbólicas que subvertem a realidade, fazendo com que desde pequena a criança entoe discursos machistas, pertencentes ao discurso patriarcal.

\section{(DES)TECENDO CAPTURAS E (NATURALIZAÇÃO DE) SENTIDOS: análises}

O discurso dessas cantigas como sistema articulado remete à prática social complexa, o discurso patriarcal, que reproduz situações conflituosas no todo social. Enquanto forma discursiva, as canções remetem necessariamente aos "sintomas pertinentes do processo de produção dominante que rege o discurso submetido à análise" (PÊCHEUX, 1993, p. 105). Há, nessas canções, sintomas de um discurso dominante, que atravessa e possibilita esses efeitos de sentido. Esses efeitos só são possíveis porque esses discursos estão inscritos nas práticas sociais e na história. Se retirada essa inscrição, não teríamos os mesmos sentidos. Diríamos a produção de um efeito: a de definir, na sociedade, lugares e modos de ser masculino e feminino.

Tomemos duas canções para analisarmos alguns versos enquanto sequencias discursivas, que tecem sentidos em relação ao gênero feminino e ao masculino. Lembrando que por se tratar de práticas relacionadas ao universo infantil, a criança está na captura do funcionamento linguístico discursivo, procurando compreender como as coisas são e funcionam, quais são os possíveis sentidos das coisas. E por isso, ao exercitar essa aprendizagem é também significada pela linguagem que Ihe significa. Porque a linguagem funciona "tanto no aprendizado verbal de crianças quanto no uso cotidiano da linguagem por outros falantes" (PÊCHEUX, 2012b, p. 104).

Ao passo que as crianças dão sentidos as suas práticas e linguagem, podem mobilizar outros sentidos em suas práticas. Ou seja, os sentidos vêm alinhavados e desalinhavados com a aquisição da linguagem. Os sentidos não são unívocos, entretanto, quando inscritos "nas regras escolares de uma assepsia do pensamento (as famosas 'leis' semântico-pragmáticas da comunicação)" (PÊ- 
CHEUX, 1994. p. 59, parênteses do autor). A escola procura um sentido único, mas é necessária a produção de sentidos de um enunciado, uma palavra, "que intervém na reprodução das relações de produção" (PÊCHEUX, 2012, p. 215). Mas é necessário o, "trabalho sobre a plurivocidade do sentido como a condição mesma de um desenvolvimento interpretativo do pensamento" (PÊCHEUX, 1994, p. 59, grifos nossos).

Vale destacar que essas canções pertencem à cultura popular, ao cultural. As canções estão no domínio público e é possível encontrá-las nas redes sociais, ouvi-las em festas infantis, entre outros espaços: "A minhoca" e "O cravo e a rosa".

\section{Tabela 1: AS CANÇÕES INFANTIS ANALISADAS}

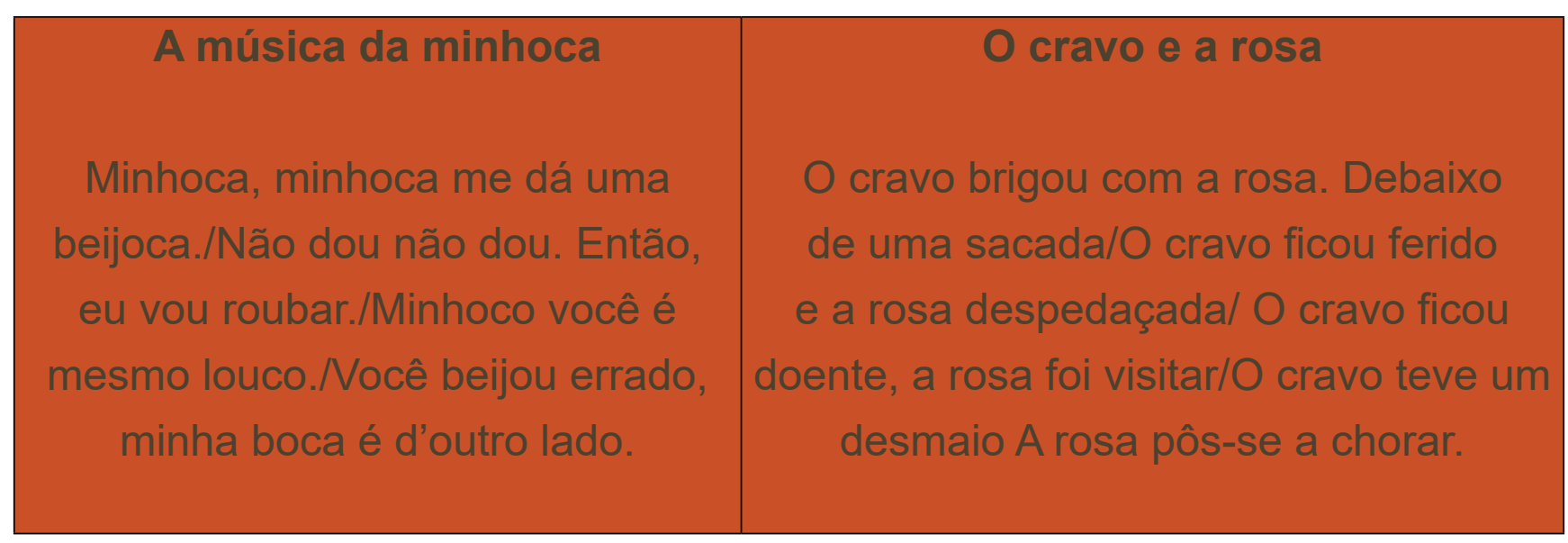

Fonte: Quadro elaborado pela autora (2021).

Nestas letras infantis, a minhoca e as flores são animizadas, ou personificadas, e metaforizadas em feminino ou masculino. $\mathbf{O}$ minhoco pede beijos para a minhoca e, diante da negativa, ele rouba. Vale ressaltar que no universo biológico a minhoca é hermafrodita e, por isso, não é definida, não há desinência nominal que indique o gênero. Entretanto, a canção marca minhoc(o) para pontuar que é o masculino que simboliza.

A relação da linguagem, por meio da mudança metafórica dos sentidos, permite alcançar o funcionamento ideológico que é inerente à materialidade discursiva. O minhoco, "na força da ordem masculina", impõe a "visão androcêntrica" ao roubar os beijos (BOURDIEU, 2010, p. 18) e comete um ato abusivo em 
relação à minhoca Há um interdiscurso que atravessa essa materialidade sob a forma do discurso machista, onde o gênero masculino possui um lugar hierarquizado, naturalizado pelas condições sociais, que lhe permite conseguir do feminino tudo que quer, mesmo que pela imposição. "[a]o poderoso macho importa, em primeiro lugar, seu próprio desejo" (SAFFIOTI, 1987, p. 18). Esse discurso provoca efeitos de sentido que o masculino, frente à negativa de um pedido, pode satisfazer seu desejo à força.

A transitividade direta do verbo roubar inscreve o discurso do minhoco como uma atitude de apropriar-se de (bem alheio), mediante violência ou ameaça: o minhoco comete violência e abuso. Discursivamente, o minhoco ocupa um efeito de lugar social masculino e se materializa interdiscursivamente. Se considerarmos o discurso jurídico brasileiro, o minhoco cometeu um crime de importunação sexual, um ato libidinoso. O Código Penal Brasileiro, após a aprovação da Lei 13.718/2018, considera que o beijo roubado constitui um crime, porque constrange a vítima. Cabette (2018), na interpretação da lei, diferencia beijo roubado de beijo furtado. O roubado envolve a violência e assim enquadraria em crime de estupro, se o beijo for furtado, é enquadrado em importunação sexual.

Historicamente, a loucura era um "comportamento inadequado" do feminino, em sua maioria, e, por isso, passível de encarceramento, intervenção física e violenta, além de suscitar estigmas. Até mesmo o casamento era recomendado como terapia estabilizante da mulher (CUNHA, 1989; PERROT, 1992; SCOTT, 1992). Assim, a loucura que interditava o feminino era requisitada pelo masculino. O feminino é considerado louco, entretanto esse lugar é requisitado pelo masculino como doença.

O beijo roubado ou furtado do minhoco interdiscursivamente busca efeitos de naturalização em relação ao desejo masculino, enquanto que o feminino é estimulado a permanecer submisso. O máximo que é dito é que o minhoco "é mesmo louco". A adjetivação de loucura para o minhoco é a solução para "resolver" a situação de violência, porque o louco é considerado doente, e não criminoso. Socialmente, quando há uma violência de gênero, a sociedade cos- 
tuma atestar loucura, "homens violentos são doentes mentais, alcoólatras, perturbados" (SAFFIOTI, 1997, p. 36). Sobremaneira atesta efeitos de sentido que no imaginário social o masculino pode agredir, pode abusar, enquanto o feminino deva suportar as agressões. Uma reprodução discursiva da inferiorização diante do abuso sexual sofrido, uma situação traumática, cantada e repetida por diversas escolas infantis. Enquanto discurso, o que é dado a significar na cantiga é o interdiscurso da ordem social, o minhoco ao roubar o beijo, pouco lhe importa, e, mais rouba do lado inverso da minhoca, ou seja, o minhoco abusa sexualmente da minhoca, quando beija do outro lado.

Em relação às flores, temos a canção infantil onde o cravo simboliza o masculino e a rosa o feminino. 0 cravo briga com a rosa, e, não a rosa briga com o cravo. Há uma memória que é da ordem do social que se inscreve nessa canção. O cravo discursiviza o masculino agressivo, corajoso, próprio da visão patriarcal, androcêntrica, falocêntrica, que se posiciona para brigar com o feminino. Há uma ordem no enunciado que coloca o cravo como sujeito da ação de brigar. E no universo das crianças é apregoado que a briga, o ato de brigar, não é uma coisa legal. Quem brigou foi o masculino com o feminino.

O cravo não conversa com a rosa, ele simplesmente briga. $\mathbf{O}$ cravo brigar com a rosa sem motivos e rememora um discurso de violência masculina, uma vez que o homem, muitas vezes, para garantir a sua supremacia, seu status de poder, recorre à violência física (empurrarão, tapas, qualquer tipo de golpe) ou psicológica (isolamento, cerceamento, humilhações, desprezos). O porquê da briga não é revelado, mas a briga denota ter sido intensa, porque a rosa sai despedaçada dessa briga. A rosa despedaçada metaforiza a violência de gênero ocorrida, a agressão que a deixou em pedaços. O despedaçar no sentido figurado denota o ato de causar dor, aflição, agonia, ou seja, a rosa ficou aos pedaços com pétalas caídas. O feminino simbolizado em flor é atravessado por efeitos de sentido interdiscursivos do imaginário social da "mulher sexo frágil". O feminino cantado nos versos, poemas, o feminino torna flor, "na linguagem popular, 'coIher a flor' de uma mulher significa destruir-lhe a virgindade, e essa expressão 
originou a palavra 'defloramento'”, ou desfloramento (BEAUVOIR, 1970, p. 197). O defloramento é uma violação. As pétalas da flor, na botânica, são as partes coloridas, visíveis, coloridas, com odores e diferentes texturas, com função de proteger os gametas (formado em seu interior) responsáveis pela reprodução. Despedaçar a rosa, metaforicamente, é tirar o brilho, a vivacidade, o colorido do feminino.

Na canção também há a preocupação que a rosa tem em relação ao cravo, mesmo depois da briga. Ela o visita e chora por encontrá-lo doente. Esses versos produzem efeitos de que, mesmo despedaçada, há que continuar preocupada, não com suas feridas, seus pedaços, mas com o cravo, o masculino. Dizendo de outra maneira, o cravo sai ferido da briga que despedaçou a rosa, e em casa, como ele está doente, a rosa, muito preocupada, visita-o e chora por seu desmaio. Um gesto associado à negatividade emocional no feminino, como se "a mulher e incapaz de usar a razão", e socorrer o cravo, além de chorar "valores considerados negativos [...] emoção, fragilidade, resignação" (SAFFIOTI, 1987, p. 34).

Num gesto de cuidado, a rosa está ao seu lado quando doente, efeitos de sentido do feminino cuidador, preocupado com o masculino. Dependendo da situação econômica de algumas famílias "encontram-se desde mulheres donas-de-casa, que se dedicam exclusivamente aos cuidados da residência, do marido e dos filhos, até aquelas que trabalham fora" (SAFFIOTI, 1987, p. 9).

A minhoca e a rosa são manipuladas forçadamente como corpos "que é preciso tornar úteis e dóceis ao mesmo tempo", como uma feminina 'deve' ser delicada (FOUCAULT, 1999, p. 297). Um discurso de naturalização quando pode ser roubado um beijo ou despedaçar esse feminino. $E$ as crianças, sujeitos desses discursos, vão reproduzindo, nas canções e em suas práticas, no falar/ cantar, em sua história enquanto sujeitos sociais e históricos. Reproduzem as cantigas enquanto processo de produção de simbolização, que interdita e reativa, constrói e reconstrói sentidos. Em outras palavras, podem se deslocar "a uma outra formação discursiva que as referências discursivas podem se construir e se 
deslocar historicamente" (PÊCHEUX, 2012b, p. 158).

Existem outras cantigas que são repetidas todos os dias por milhões de crianças. Mas não cabem apenas em um artigo, entretanto, sabemos que o discurso geralmente é apresentado em fragmentos, "feito de cacos e de fragmentos, é que ele permite recuperar as condições concretas da existência das contradições através das quais a história se produz, sob a repetição das memórias estratégicas" (PÊCHEUX, 1981, p. 7, tradução minha). ${ }^{1}$

O discurso sobre o lugar do feminino e do masculino são discursivizados em outras redes de filiações, outras materialidades, fazendo com que esses sentidos retornem. Eles são retomados, reestruturados, uma vez que pertencem a uma rede de memórias, inscritas na história. Não é o masculino e feminino empírico, mas o imaginário dessas diferentes posições discursivizadas, que aparecerão "necessariamente [como] um espaço móvel de divisões, de disjunções, de deslocamentos e de retomadas, de conflitos de regularização" (PÊCHEUX, 2012a, p. 56). Mas é a incidência do aparecimento em mais de uma canção, ou em várias superfícies, que permite perceber a presença discursiva, "ao multiplicar a presença do discurso por ele mesmo, manifestar a estrutura invariante do processo de produção [...] cujas variações são o sintoma" (PÊCHEUX, 1993, p. 98, grifos nosso).

Mas é, também, necessário, enquanto analista, a tentativa de expor esses discursos que tentam multiplicar seus efeitos de maneira invariante através das crianças, porque "é através da linguagem enquanto Ação sobre o Outro [...] e enquanto Ação sobre o Mundo [...] que a criança constrói a linguagem enquanto Objeto sobre o qual vai poder operar" (DE LEMOS, 1982, p. 13, grifos da autora). Os efeitos discursivos emergem através dos enunciados proporcionados pelo outro, com toda carga simbólica, sócio-histórico-cultural, no funcionamento linguístico discursivo dado a simbolizar, significar as coisas no mundo.

$1 \quad$ L'intérêt de cet hétérogène discursif, (fait de bribes et de fragments, c'est qu'on y repère les conditions concrètes d'existence des contradictions à travers lesquelles de l'histoire se produit, sous la répétition des mémoires "stratégiques»"). 


\section{UM FIO PARA AMARRAR, MAS NÃO FINALIZAR...}

Os discursos materializados nas cantigas infantis, embora linguisticamente diferentes, discursivizam em seus versos sentidos parecidos: ambas metaforizam a violência em relação ao feminino e talvez não fizessem esse sentido em outras condições de produção, sem a presença dos movimentos feministas. Ou seja, os efeitos de sentido produzidos pelas duas canções, em relação ao feminino, são de submissão, abuso, subserviência. Enquanto que o masculino aparece no lugar de agressor. Podendo até se destacar em outras canções mais adultas, por exemplo na interpretação da cantora Maria Gadú, na composição de Gugu Peixoto / Luis Kiari, que afirma: "a linda rosa perdeu pro cravo".

Os discursos se repetem: a rosa, a minhoca e tantos outros enunciados sobre o feminino ainda discursivizam de maneira ritualizada o funcionamento para a manutenção de uma sociedade patriarcal e machista, de submissão ao feminino. Com efeito, se é por meio do Outro que os sentidos, as significações são atribuídas, tentamos, pois, fazer de nossas práticas um atravessamento neste imaginário que se tem do masculino e do feminino, para buscar a produção de outros dizeres, outras cantigas, outras práticas mais igualitárias, contestando o que está sendo dito, e como está sendo dito. Isso é de responsabilidade de todos: pais, responsáveis, escola, sociedade. Volto aqui à epígrafe, vamos ressoar outros discursos, outras práticas na história, ressignificar masculino e o feminino, numa perspectiva igualitária às crianças. Para tal, cantemos outras canções, resignifiquemos, na busca de criar brechas, lacunas, audíveis a outros discursos e práticas. Novas "formulações que se travem embate para se afastar de outras [...] com as quais [..] não se identificam [...] tantas outras [...] que poderiam promover acontecimentos discursivos que resultariam em outros discursos" (SANTOS, 2013 , p. 138). 


\section{REFERENCIAS}

BRASIL. Ministério de Educação e Cultura. LDB - Lei n 9394/96, de 20 de dezembro de 1996. Estabelece as diretrizes e bases da Educação Nacional. Brasília: MEC, 1996.

BRASIL. LEI no 11.769, de 18 de agosto de 2008. Altera a Lei $n^{\circ} 9.394$, de 20 de dezembro de 1996, Lei de Diretrizes e Bases da Educação, para dispor sobre a obrigatoriedade do ensino da música na educação básica. Disponível em: http://www.planalto.gov.br/ccivil_03/_Ato2007-2010/2008/Lei/L11769.htm. Acesso em: 6 nov. 2019

BRASIL. LEI $\mathbf{n}^{\circ} \mathbf{1 3 . 2 7 8}$, de 2 de maio de 2016. Altera o $\S 6^{\circ}$ do art. 26 da Lei ${ }^{\circ}$ 9.394, de 20 de dezembro de 1996, que fixa as diretrizes e bases da educação nacional, referente ao ensino da arte. Disponível em: http://www.planalto.gov.br/ ccivil_03/_Ato2015-2018/2016/Lei/L13278.htm. Acesso em: 6 nov. 2019

BEAUVOIR, Simone. O segundo sexo: fatos e mitos. Trad. Sérgio Milliet. $4^{\mathrm{a}}$ ed. São Paulo: Difusão Europeia do Livro, 1970.

BRITO, Teca de Alencar. Música na educação infantil: propostas para a formação integral da criança. São Paulo: Petrópolis, 2003.

CABETTE, Eduardo Luiz Santos. Primeiras impressões sobre o crime de importunação sexual e alterações da Lei 13.718/18. Revista Jus Navigandi. ISSN 1548-4562, Teresina, ano 23, n. 5620, 20 nov. 2018. Disponível em: https://jus. com.br/artigos/70388. Acesso em: 1 dez. 2019.

CUNHA, Maria Clementina Pereira. Loucura, gênero feminino: as mulheres do Juquery na São Paulo do início do século XX. Revista Brasileira de História, 9(18), 1989 p. 129-144.

DE LEMOS, Cláudia Thereza Guimarães. Das vicissitudes da fala da criança e de sua investigação. Cadernos de Estudos Linguísticos, Campinas, (42): 4169, jan./jun. 2002.

DE LEMOS, Claudia. T. G. Sobre Aquisição de Linguagem: e seu Dilema (Pecado). Original. Boletim da ABRALIN 3(97-136). 1982. 
FOUCAULT, Michel. Em defesa da sociedade: curso no College de France (1975-1976). São Paulo: Martins Fontes, 1999.

LACAN, Jacques. O Seminário, livro 11: os quatro conceitos fundamentais da psicanálise. Jorge Jahar Editor. 1988.

PÊCHEUX Michel. L'étrange miroir de l'analyse de discours. Langages, 15e année, $\mathrm{n}^{\circ}$ 62, 1981. Analyse du discours politique. p. 5-8. Disponível em: https:// www.persee.fr/doc/lgge_0458-726x_1981_num_15_62_1872. Acesso em: 10 nov. 2019.

PÊCHEUX, Michel. Papel da memória. Campinas: Pontes. 2007.

PÊCHEUX, Michel. Análise automática do discurso (AAD-69). In: GADET, Françoise; HAK, Tony (Orgs.). Por uma análise automática do discurso: uma introdução à obra de Michel Pêcheux. Trad. Bethania S. Mariani et al. 3. Ed. Campinas: Editora da Unicamp, 1993.

PÊCHEUX, M. Ler o arquivo hoje. Tradução Maria das Graças Lopes Morin do Amaral. In: ORLANDI, E. Gestos de Leitura. 2 ed. Campinas: Editora da Unicamp, 1994.

PÊCHEUX, Michel. O discurso: estrutura ou acontecimento. Tradução: Eni Puccinelli Orlandi, $4^{\mathrm{a}}$ edição. Campinas, SP: Pontes Editores, 2012a.

PÊCHEUX, Michel. Análise de Discurso: Michel Pêcheux. Textos escolhidos por Eni Puccinelli Orlandi. Campinas, SP: Pontes Editores, 2012b.

PÊCHEUX, Michel. Semântica e Discurso: uma crítica à afirmação do óbvio. Trad. de Eni P. Orlandi. 2. Ed. Campinas: Editora da Unicamp, 2009.

PERROT, Michelle. Os excluídos da história: operários, mulheres e prisioneiros ( $2^{a}$ ed.). Rio de Janeiro: Paz e Terra, 1992.

SAFFIOTI, Heleieth I. B. O poder do macho. São Paulo: Moderna, 1987.

SAFFIOTI, Heleieth I. B. Gênero, patriarcado, violência. $1^{\circ}$ ed. São Paulo: Fundação Perseu Abramo, 1997. 
SANTOS, Eliana Cristina Pereira. A imagem do professor nas capas da Revista Nova Escola: a circularidade de sentidos. 2013. 148 f. Dissertação (Mestrado em Linguagem e Sociedade) - Universidade Estadual do Oeste do Paraná, Cascavel, 2013.

SCOTT, Joan. História das mulheres. In: P. Burke (Org.). A escrita da história: novas perspectivas ( $4^{\mathrm{a}}$ ed.). São Paulo: UNESP, 1992. p. 63-95. 


\section{dol $10.48209 / 978-65-89949-24-3$}

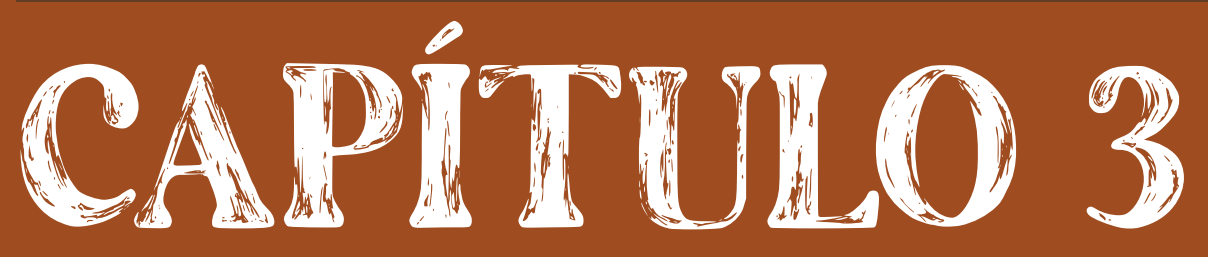

\section{A GERAÇÃO DIGITAI COMO IDENTIDADE CULTURAL NA CONHEMPORANEIDADE}

Sandro Faccin Bortolazzo 


\section{INTRODUÇÃ ${ }^{2}$}

Nos últimos 20 anos, a ideia de crianças e jovens como especialistas em tecnologia tem se proliferado nos meios de comunicação, inclusive no debate acadêmico. É recorrente encontrar nos jornais e revistas, nos programas de televisão, na internet, incontável número de expressões que indicam uma naturalização da relação entre os mais jovens e as tecnologias: Geração Digital, Nativos Digitais, só para citar alguns exemplos. Essas nomenclaturas têm enfatizado a destreza dos jovens em operar computadores, telefones celulares, entre inúmeros outros aparelhos eletrônicos, para as mais diversas finalidades entretenimento, aprendizagem, informação, consumo, participação em redes de sociabilidade.

Inscrito no referencial teórico dos Estudos Culturais de inspiração pósestruturalista, este estudo se dedica a investigar a produção da Geração Digital no Brasil como um tipo de identidade cultural presente na sociedade contemporânea. O estudo procurou problematizar a emergência da Geração Digital a partir da interlocução entre Tapscott (1999; 2009), Prensky (2001) - autores pioneiros no estudo sobre a temática da relação encarada pelos jovens com as tecnologias - e certas representações midiáticas. O estudo apresentado tem por objetivo discutir algumas condições que têm permitido atrelar aos mais jovens um rótulo geracional específico e sinalizar um denominador comum balizado pela conexão desses sujeitos com os artefatos eletrônicos digitais.

Os conceitos de identidade, geração e representação são empregados nesse artigo para pensar a produção da Geração Digital. Essas ferramentas são utilizadas segundo análises empreendidas por autores como Bauman (2005; 2011), Hall (1997; 2004), entre outros teóricos.

A pesquisa contemplou dois movimentos de investigação. O primeiro foi uma aproximação com a literatura especializada sobre o assunto a partir de dois

2 Artigo apresentado no X Anped SUL. Florianópolis, outubro de 2014. 
estudos que, na metade da década de 1990 e início dos anos 2000, começaram a acionar alguns termos como Geração Digital (TAPSCOTT,1998; 2010) e Nativos Digitais (PRESNKY, 2001). O segundo movimento de investigação buscou identificar certas representações dos sujeitos da Geração Digital na mídia brasileira, tendo como material de análise três reportagens de capa da revista Época.

Proponho, dessa forma, discutir o que tornou possível certas formas de representar e de estar no mundo sobre esta geração ligada ao universo das tecnologias digitais.

\section{GERAÇÃO E IDENTIDADE}

Nenhum ser humano é exatamente igual a outro - e isso se aplica tanto aos jovens quanto aos velhos. Contudo, é possível notar que, em determinadas categorias de seres humanos, algumas características ou atributos tendem a aparecer com maior frequência que em outras. É essa "condensação relativa" de traços característicos que nos permite falar, em primeiro lugar, em "categorias", sejam elas nações, classes, gêneros ou gerações. Ao fazê-lo, ignoramos temporariamente a multiplicidade de características que faz de cada um de seus integrantes uma entidade única e irrepetível, diferente de todas as outras, um ser que se destaca de todos os demais membros da "mesma categoria" [grifos do autor] (BAUMAN, 2011, p.58).

Por que geração? Que elementos permitem classificar como geração e como Digital um conjunto da população jovem imersa nos aparatos tecnológicos? O conceito de geração tem sido utilizado de inúmeras maneiras. Um dos significados mais aceitos é, sem dúvida, aquele que relaciona geração à idade biológica, ou seja, o período de sucessão entre descendentes em linha reta (avós, pais, filhos, netos, e assim por diante). De acordo com Jaeger (1985), foi Auguste Comte, entre 1830 e 1840, o primeiro a iniciar um estudo científico sobre o conceito de geração. A primeira acepção do termo apresentada por Comte e ligada ao positivismo identificava o tempo como objetivamente mensurável. No entendimento de Comte, o ritmo das gerações poderia ser calculado simplesmente a partir da "medição do tempo médio necessário para que uma geração seja 
substituída na vida pública - por uma nova" (COMTE apud FEIXA e LECCARDI, 2010, p.187).

Ressalta-se também Wilhelm Dilthey, primeiro pensador que introduziu um conceito histórico de geração. A abordagem inspirada em Dilthey é analisada sob um ponto de vista historicista a partir da conexão entre os ritmos da história e os ritmos das gerações. Para esse autor, a geração exige uma análise do tempo de experiências medido exclusivamente em termos qualitativos e "baseada em uma temporalidade concreta, constituída de acontecimentos e experiências compartilhadas" (FEIXA; LECCARDI, 2010, p.188).

A atualidade do conceito de geração em muito se deve ao pensamento de Mannheim quando da publicação do artigo “O Problema das Gerações”3. Quando Mannheim desenvolveu uma teoria das gerações, ele teve um duplo objetivo: distanciar-se do positivismo, bem como da perspectiva histórica. Mannheim (1982) considerou o termo geração associado à própria dinâmica das transformações sociais. Segundo Mannheim (1982), as gerações podem ser consideradas resultados de muitas descontinuidades produzidas exatamente por mudanças históricas e sociais. Em outras palavras, o que o autor argumenta é que o que forma uma geração não é a data de nascimento em comum, mas o processo histórico que uma parcela da população compartilha (FEIXA; LECCARDI, 2010).

Na mesma esteira conceitual exposta por Mannheim, as contribuições de Philip Abrams oferecem outra perspectiva para pensar o conceito de geração. Esse autor amplia a noção histórica e social produzida por Mannheim e relaciona o termo geração à questão identitária, entendida aqui como o resultado do entrelaçamento das histórias social e individual. "O ponto de partida de Abrams foi sua convicção de que a individualidade e a sociedade são construções históricas. Seria, portanto, necessário, analisar suas interconexões e, simultaneamente, suas mudanças ao longo do tempo" (FEIXA e LECCARDI, 2010, p. 190).

3 A versão original data de 1928. Utilizo aqui a versão traduzida de 1982. MANNHEIM, Karl. O problema sociológico das gerações [tradução: Cláudio Marcondes], In Marialice M. Foracchi (org), Karl Mannheim: Sociologia, São Paulo, Ática, 1982 p. 67-95. 
Assim, é possível falar que novas gerações criam outras identidades e que as gerações "não surgem da cadência temporal estabelecida por uma sucessão de gerações biológicas. Em outras palavras: não há padronização do tempo para medir ou prognosticar seu ritmo" (FEIXA; LECCARDI, 2010, p. 191). Uma geração pode sim ser compreendida num período de 10 anos, por exemplo, mas também cessa quando novos e grandes eventos históricos, ou melhor, quando processos econômicos e de natureza cultural tornam o sistema anterior e todas as experiências relacionadas a ele sem significado.

Por sua ampla utilização, o termo identidade tem sido empregado como um conceito guarda-chuva. Há, de fato, uma preocupação explicita na contemporaneidade com as questões que dizem respeito à identidade. De acordo com Bauman (2005), a globalização, o declínio dos Estados Nacionais e a decadência do Estado de Bem-Estar Social, o aumento da mobilidade social, a maior flexibilidade nos empregos, a insegurança nas relações sociais, entre outras circunstâncias, contribuiu para o desenvolvimento de estados de permanente fragmentação e incerteza. Os lugares tradicionalmente investidos de sentimentos de pertença como a Família e a Igreja acabam sendo colocados a prova e "no admirável mundo novo das oportunidades fugazes e das seguranças frágeis, as identidades ao estilo antigo, rígidas e inegociáveis, simplesmente não funcionam" (BAUMAN, 2005, p.33).

Concordo com Bauman (2005), quando da entrevista concedida a Benedetto Vecchi sobre o tema da identidade:

Tornamo-nos conscientes de que o "pertencimento" e a "identidade" não têm a solidez de uma rocha, não são garantidos para toda a vida, são bastante negociáveis e revogáveis, e de que as decisões que o próprio indivíduo toma, os caminhos que percorre, a maneira como age - e a determinação de se manter firme a tudo isso - são fatores cruciais tanto para o "pertencimento" quanto para a "identidade" [grifos do autor] (BAUMAN, 2005, p. 17).

A problemática apresentada conecta geração ao digital. Quer dizer, desde o final da década de 1990, uma série de reportagens jornalísticas, pesquisas 
acadêmicas e aquelas voltadas ao mercado - amiúde interconectadas - tem procurado destacar a produtiva e intensa relação entre crianças e as novas tecnologias. Muitos desses textos não hesitam em ressaltar o "nascimento" de uma distinta Geração Digital. Inevitavelmente, através de algumas representações midiáticas é possível vislumbrar um lugar onde a Geração Digital também é produzida. Os processos de representação na mídia não apenas tornam conexões, relações e identidades visíveis, eles os constituem, ou seja, formam tais conexões, relações e identidades.

Para Hall (1997), o conceito de representação é apreendido como parte da construção de sentidos, produzidos e intercambiados por membros de uma mesma cultura. Em uma acepção mais simples pronunciada pelo autor, a representação se dá na "conexão entre os conceitos e a linguagem que nos permite referir ao mundo 'real' ou 'imaginário' dos objetos, pessoas e eventos" [grifos do autor] (HALL, 1997, p. 17). A representação, de certa forma, é um tipo de inscrição. Nesse sentido, não há como considerar a existência de uma identidade cultural dos sujeitos da Geração Digital fora dos processos de representação.

\section{GERAÇÃO DIGITAL E NATIVOS DIGITAIS}

As diversas representações de uma grande parcela da população de crianças e jovens como adepta de aparatos tecnológicos digitais não tiveram início, obviamente, com certas denominações, a exemplo da Geração Digital ou dos Nativos Digitais. Há uma variedade de representações que participaram, ao longo do século $X X$, da constituição de uma cultura e de uma sociedade que vem investindo intensamente nas tecnologias digitais. Assim, trabalho com a ideia de que certa identidade cultural de jovens conectadas aos aparatos eletrônicos digitais é produto das formas de representar e de falar sobre essa geração. Sobre isso, Costa (2000, p.42) acrescenta que "quem tem o poder de narrar o outro, dizendo como está constituído, como funciona, que atributos possuem, é quem dá as cartas da representação, ou seja, é quem estabelece o que tem ou não tem estatuto de realidade". 
Um dos estudos pioneiros na análise das relações encaradas pelos jovens e as novas tecnologias, lançado em 1998 - Growing up digital: the rise of the net generation (sem tradução no Brasil) - registra algumas características dos jovens que cresceram fazendo uso de aparatos tecnológicos. Don Tapscott ${ }^{4}$ tenta prever as transformações que poderiam ocorrer a partir dessa relação e afirma que a participação dessa geração na formação de uma cultura do século XXI por meio das tecnologias digitais corresponde a uma verdadeira revolução, cujos precedentes só podem ser comparados ao impacto da televisão na vida dos Baby Boomers ${ }^{5}$.

Para Tapscott (1998) a peculiaridade da Geração Digital está atrelada ao fato de terem nascido em meados da década de 1990 - momento econômico no qual a efervescência de parafernálias digitais passou a fazer parte do cotidiano dos jovens norte-americanos (reduto da pesquisa do autor) - e de estarem crescendo cercados pelas mídias digitais. Como resultado, pela primeira vez na história, os mais jovens passariam a ter domínio sobre algo em relação aos adultos: as tecnologias, hoje consideradas centrais para o desenvolvimento das sociedades. Conforme Tapscott (1999), a Geração Digital estaria exercendo um papel de liderança uma vez que nem seus pais ou mesmo professores possuiriam uma expertise tecnológica.

De certa forma lidar com as tecnologias digitais tem sido mais fácil para os jovens do que para os adultos, reafirma Tapscott (1999). Isso porque os mais jovens teriam passado por um processo de assimilação direta das tecnologias, enquanto para os adultos essa destreza envolveria tempo de aprendizagem.

4 Don Tapscott é canadense, escritor, pesquisador, palestrante e consultor especializado em estratégia corporativa além de ter virado o verdadeiro "guru" da Geração Digital. Ele dirige a empresa Ngenera, realizando pesquisas com sujeitos da Geração Digital e desenvolve programas para a área da educação à distância.

$5 \quad$ As pessoas que nasceram entre o final da década de 1940 e a metade dos anos 1960, segundo Tapscott (1998) estão vinculadas ao aumento dos índices de natalidade do período pós-guerra. Ao final da Segunda Guerra Mundial (1939 - 1945), o mundo presenciava o nascimento de uma geração: os chamados Baby Boomers. Nos Estados Unidos, por exemplo, a volta dos soldados para as famílias fez com que houvesse um aumento no número de mulheres grávidas e daí surgiu o termo boom, que em inglês significa, entre outras coisas, aumento rápido ou crescimento súbito. Por esta razão, a geração que aí se formou é chamada de Baby Boomers 
Grown up digital: how the net generation is changing your world (2009), no Brasil foi publicado em 2010 e traduzido como A hora da Geração Digital - como os jovens que cresceram usando a internet estão mudando tudo, das empresas aos governos. Nele, Tapscott (2009) entrevistou mais de 10 mil crianças e jovens com o intuito de avaliar como se dão as sociabilidades desse conjunto da população quando ingressam no universo da cultura digital. Contrapondo muitos estudos que acusam essa geração de superficial, carente em termos de concentração e pobre em habilidades sociais, Tapscott (2009) conclui que esses jovens, ao contrário, teriam desenvolvido novas formas de pensar, interagir, trabalhar e socializar. Mesmo apresentando uma série de argumentos a favor da Geração Digital, uma das críticas que o autor desenvolve é com relação aos perigos da exposição em excesso. A exibição exacerbada dos jovens junto às redes sociais, compartilhando informações pessoais, fotografias, vídeos caseiros, é um dos motivos de maior preocupação por parte do autor. A privacidade, na visão de Tapscott (2009), seria um problema ainda não resolvido por essa geração - fato que demandaria atenção e uma discussão mais ampla.

Os argumentos de Tapscott (2009) se baseiam em dois conjuntos binários de oposições - tecnologia (internet versus televisão) e Gerações (Baby Boomers versus Geração Digital). Nesse debate, Buckingham (2007) têm sido um dos autores que levanta muitas críticas sobre a presença tecnológica na vida dos mais jovens e analisa como as noções têm se apoiado em certo determinismo tecnológico, sem a crítica necessária às generalizações produzidas pelos especialistas. Na crítica à Tapscott, a televisão é vista como passiva, enquanto a internet é ativa; a televisão emburrece seus usuários, enquanto a internet aguça sua inteligência; a televisão difunde uma única visão de mundo, enquanto a internet é democrática e interativa; a televisão isola, enquanto a internet cria comunidades; e assim por diante (idem, 2007, p.34).

Em outro estudo publicado em 2001, o educador e desenvolvedor de jogos eletrônicos Mark Prensky criou duas categorias - os Nativos e os Imigrantes Digitais. Além de ter sido o criador das denominações, o autor publicou uma série de livros que se baseiam nessas duas indicações, principalmente, apontando as transformações nos processos educativos com o ingresso das tecnologias nos 
ambientes escolares. Segundo o autor, o mundo marcado pelas tecnologias estaria dividido entre os Nativos e os Imigrantes Digitais. A fluência com os artefatos eletrônicos, para usar uma expressão de Prensky (2001), teria transformado os jovens em especialistas digitais, possuidores de uma capacidade múltipla, ou seja, aptos a utilizar diversas mídias ao mesmo tempo. Nesse sentido é que o autor vai classificá-los como "Nativos" em oposição aos seus pais ou professores que nasceram antes e que, portanto, seriam os "Imigrantes Digitais".

Prensky (2001) utiliza uma linguagem objetiva apostando incontestavelmente que as tecnologias são apreendidas e compreendidas de maneiras distintas pelos sujeitos das diferentes Gerações. Os estudantes de hoje representam a primeira geração que cresceu com as novas tecnologias. Eles passaram suas vidas inteiras cercadas por e usando computadores, videogames, tocadores de música digital, câmeras de vídeo, telefones celulares e todos os outros brinquedos e ferramentas da era digital. Um estudante comum hoje teria passado menos de 5.000 horas lendo, e mais de 10.000 horas jogando videogames (sem mencionar às 20.000 horas assistindo televisão). Jogos de computador, e-mail, internet, telefones celulares e comunicadores instantâneos são parte integral de suas vidas (PRENSKY, 2001, p. 1). "Os instrutores de hoje são Imigrantes Digitais que estão lutando para ensinar aos alunos Nativos que falam uma linguagem inteiramente nova" (Prensky, 2001, p.3).

O autor parece preocupado em convocar os profissionais da educação a encararem essas supostas diferenças geracionais e reconhecerem as reconfigurações dos bancos escolares. Prensky (2001) recorre ao termo Imigrante distinguindo que os sujeitos de outras Gerações estariam passando por uma espécie de "alfabetização digital" e que possuiriam um "sotaque" diferente dos Nativos. Para detectar essa diferença, o sotaque seria o grande demarcador. Segundo o autor, atividades cotidianas que envolvem a interação com os computadores podem comprovar tal distinção. Há inúmeros exemplos citados por Prensky (2001); os Imigrantes têm o hábito de ligar para o amigo confirmando se ele recebeu um e-mail, o que na ótica de um Nativo seria um despropósito; os Imigrantes costumam ler manuais de instrução antes de operar qualquer aparelho eletrônico enquanto os Nativos esperam que os próprios 
aparelhos sejam autoexplicativos. Seguindo Prensky (2001), há uma determinada "descontinuidade" entre Nativos e Imigrantes Digitais que não se limitaria a questões simples, mas a processos complexos, promovidos principalmente pelo uso que fazem das mídias digitais.

\section{O PRODÍGIO TECNOLÓGICO E O IMPERATIVO DA VELOCIDADE}

As reportagens que se dedicam a narrar os "legítimos" integrantes da Geração Digital constantemente sugerem uma expertise natural das crianças com as tecnologias. Esse diferencial emerge necessariamente com o objetivo de prescrever horizontes de explicação a respeito de uma população (ROSE, 1998). Os textos propagam os feitos das crianças que utilizam as tecnologias digitais mais cedo que seus pais. Por esta razão, teriam desenvolvido uma destreza com os aparatos eletrônicos que os colocam, muitas vezes, em vantagem com relação aos sujeitos de outras gerações. Algumas reportagens corroboram essa hipótese concordando com os pressupostos geracionais de autores como Prensky (2001) e Tapscott (1999; 2009). Analisamos a capa da revista Época de 10 de setembro de 2007

Figura 1 - Eu amo meu computador

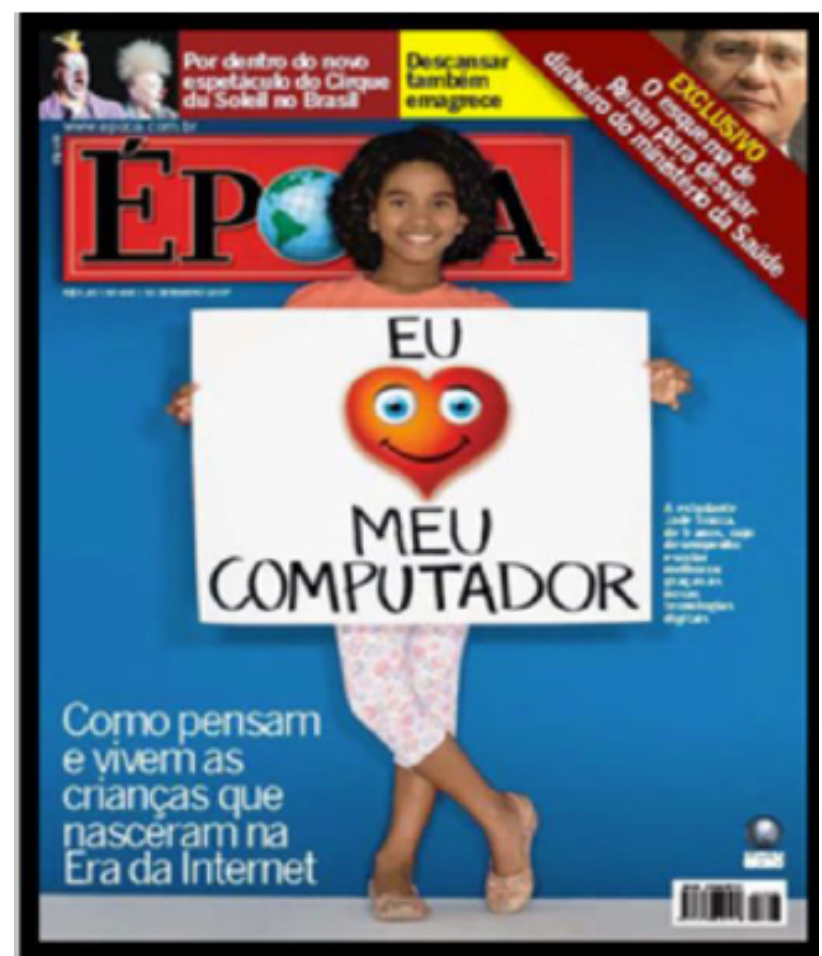

Fonte: Revista Época de 10 de setembro de 2007 
A ilustração de capa mostra uma menina segurando um cartaz com os dizeres já anunciados, sendo que a palavra "amor" não aparece. Ela é substituída por um coração ao estilo emotions. O texto inicial da reportagem confere uma explicação de como a pesquisas têm rotulado essas crianças e jovens, assumindo desde então o desígnio geracional de Prensky (2001):

Os nativos digitais têm contato com a tecnologia logo após o nascimento. Crianças com menos de 2 anos já se sentem atraídas por vídeos e fotos digitais. A intimidade com o computador, porém, costuma chegar aos 4 anos. Nessa idade, já deslizam o mouse olhando apenas para o cursor na tela. Aos 5, reconhecem ícones, sabem como abrir um software e começam a se interessar pelos primeiros jogos virtuais, como os de associação ou de memória. Claro que, como em qualquer outra atividade, a desenvoltura nas telas variará de criança para criança. Aos 7, é a hora do primeiro grande marco tecnológico na vida dos nativos: eles criam um e-mail, a identidade para quem navega no mundo virtual (Época, 2007, p.83).

O uso constante que fazem das tecnologias seria uma das imagens marcantes dos sujeitos da Geração Digital, que são narrados como se, desde cedo, já se sentissem encantados, inebriados e aptos a lidar com os aparatos digitais. Esse tipo de representação me parece exclusiva dessa geração, uma vez que tanto o acesso e o consumo das tecnologias quanto à importância dada a elas, hoje, ganham outra roupagem e significativa importância. Na década de 1970, por exemplo, "os adolescentes foram tão atraídos, seduzidos e bajulados pelas maravilhas de videogames, rádios portáteis ou sessões de cinema quanto os de hoje" (BAUMAN, 2011, p.54), mas todos eram demasiadamente onerosos. Há pouco tempo, artefatos como videogames e computadores eram tidos como artigos supérfluos, desnecessários. Possuir algum aparelho eletrônico e ter acesso a eles era encarado como "sorte grande, sopros de ventos particularmente generosos e benevolentes, e não como expectativas legítimas - e sem dúvida não como uma questão de direito ou obrigação" (BAUMAN, 2011, p.54).

Ao final da década de 1970 e início dos anos 1980, o desenvolvimento tecnológico em direção a informatização (computadores pessoais e internet) passou a produzir uma cultura tecnológica mais generalizada que tem se 
alastrado até a atualidade. É a partir desses processos que as representações sobre os sujeitos jovens da era digital se tornam mais persuasivos, na medida em que também representam certos modelos de comportamento ajustados ao regime tecnológico global e em rede. Ou seja, não é possível negar a proliferação de artefatos tecnológicos entre os jovens, tampouco contestar o consumo de toda essa parafernália digital. No entanto, asseguro junto com Buckingham (2007) que grande parcela de crianças e jovens não sabem como operar naturalmente computadores e videogames. Muitas vezes, assim como os adultos, experimentam sentimentos como tédio, confusão e frustração. "Em geral, essa vivência tecnológica tem sido experimentada por poucos e os benefícios criativos, educacionais e comunicativos dessas tecnologias são apenas percebidos por uma pequena elite" (BUCKINGHAM, 2007, p. 39).

Os autores da reportagem de Época (2007) desenvolvem o texto a partir dos conceitos propostos por Prensky (2001) convocando os leitores a identificarse com os Nativos ou com os Imigrantes Digitais. Entre os vários modelos de exemplares dessa "espécie nativa" retratada no texto está o menino Gustavo Altman de nove anos e fanático por futebol. É um menino que utiliza as tecnologias para consumir tudo o que é tipo de informação referente ao universo do futebol. $O$ menino é blogueiro mirim e escreve todos os dias seus comentários dedicados ao esporte. Esse parece ser um exemplo "saudável" da relação com as tecnologias. "Adoro jogar bola, mas às vezes fico em dúvida entre o futebol e o computador" (Época, 2007, p.84).

Um dos modos de ser jovem nas sociedades contemporâneas vem sendo construído pelo que se descreve a respeito dos videogames, dos smartphones, dos computadores, dos tablets. Certamente essa representação mostrando o quanto a vida dos mais jovens está cercada pelas tecnologias, o que os capacitaria a operar diversas mídias, não existiria sem o ingresso e o consumo de artefatos digitais. Os aparelhos eletrônicos, por exemplo, não criaram nenhuma necessidade, no máximo estão tornando-as mais agudas e, portanto, seria "tolice, 
além de injusto, culpar apenas a eletrônica pelo que está acontecendo com as pessoas que nascem num mundo interligado por conexões a cabo, com fio ou sem fio" (BAUMAN, 2011, p.14). A

Aulas de inglês, de espanhol, natação, futebol, vôlei, lições de casa, papo ao telefone, navegação na internet, o rádio ligado. São crianças e jovens com agendas tão cheias quanto às de executivos, que envolvem jornadas de intensidade típica do regime tecnológico, obrigando os sujeitos a adotarem a velocidade e o imediatismo como padrão de vida. As matérias, muitas vezes, acompanham o dia a dia dos jovens, coletando depoimentos dos pais e dos professores e se espelham nas pesquisas de especialistas que vão diagnosticando questões referentes ao uso das variadas mídias ao mesmo tempo - a falta de concentração, o desenvolvimento motor e emocional, o aumento no nível de QI.

O tema do sujeito jovem "multitarefa" é revelado nos primeiros parágrafos da reportagem de Época (2007, p. 85): Elas fazem amigos pela rede, conhecem o mundo pelos buscadores, desenvolvem habilidades por meio de videogames, criam páginas em redes sociais. Além de navegar na internet, são capazes de operar outros aparelhos eletrônicos com muita facilidade, como celulares, controles remotos, às vezes vários ao mesmo tempo. "Eles migram de um software para outro, como se trocassem a gangorra pelo balanço", afirmou Prensky a Época.

Assim como o navegar por diferentes atividades tem sido uma marca representativa da Geração Digital, a velocidade com que mudam de uma tela para outra, concentra, muitas vezes, apenas as virtudes desse novo tipo de sujeito jovem que emerge. A multiplicidade de acontecimentos veiculados 24 horas por dia pela internet, por exemplo, de alguma maneira, serve para alertar que uma cultura apressada e veloz está produzindo outras formas de habitar o espaço. O que se tem como resultado é um tempo líquido, móvel, sem um princípio, meio e fim determinados, cheios de presentes contínuos, intermitentes. Essa imagem possui intrínseca relação com a valorização dos atributos necessários à participação em uma sociedade caracterizada como efêmera, provisória, líquida (BAUMAN, 2001). 
Com a habitual rotina acelerada, as reportagens tentam radiografar a Geração Digital e o tom dos textos, frequentemente, beira entre o entusiasmo e a preocupação. Em Época de 3 de novembro de 2003 divulga-se na capa a fotografia (Figura 2) de um menino vestido de preto, usando óculos escuros (referência nítida ao filme Matrix) e surfando numa prancha em forma de mouse. A imagem tem como protagonista um garoto aparentando não mais que 10 anos de idade, surfando sobre um mouse em um mar de informações, o qual ao invés de água, é composto de signos, números, letras e códigos. Elementos esses que nos remetem diretamente ao universo digital. $O$ título da matéria Inteligência Turbinada já marca uma relação positiva da tecnologia com o aumento da inteligência.

Figura 2 - Inteligência Turbinada

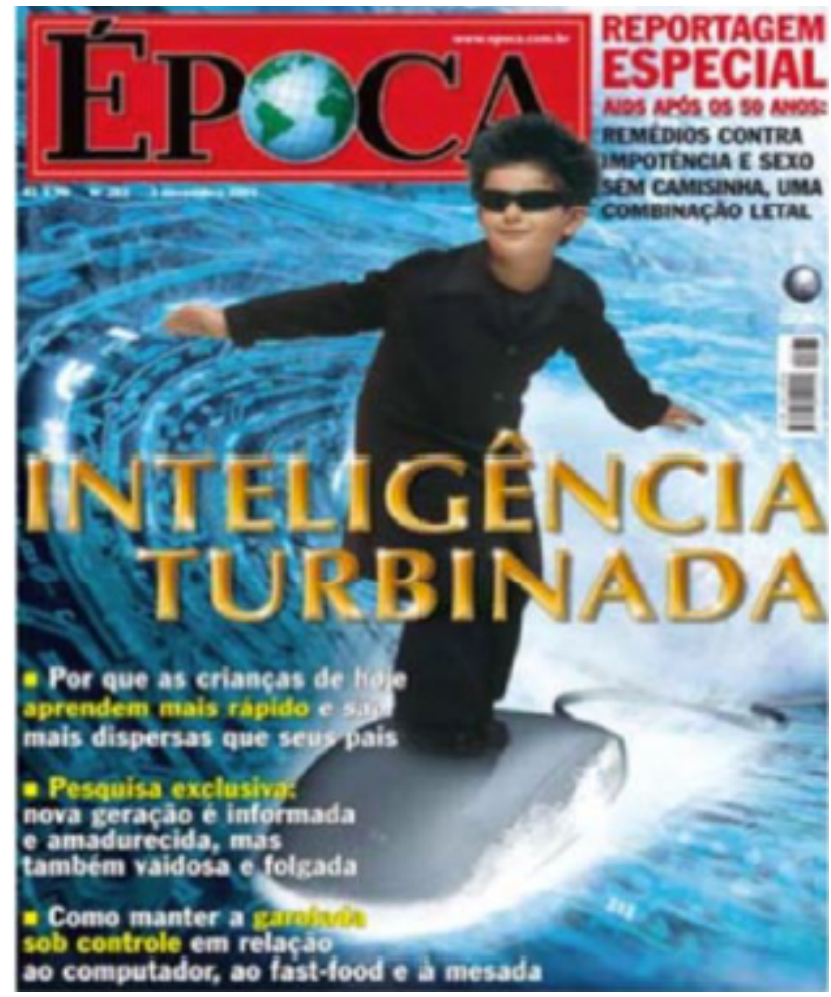

Fonte: Revista Época de 03 de novembro de 2003

Nessa mesma reportagem há todo um apanhado histórico indicando que o volume do cérebro humano dobrou de tamanho desde que os homens primitivos começaram a andar sobre dois pés e, baseado em um estudo da Universidade de Cornell, nos Estados Unidos, confirma-se que "o Q.I., que mede o raciocínio 
linguístico, matemático e lógico, vem aumentando em média 20 pontos por geração" (Época, 2003, p.81). Fundamentado no mesmo estudo, mencionam que os jovens da era digital alcançam até 25 pontos a mais que seus avós e concluem: "nesse ritmo, uma pessoa que tenha hoje um desempenho na média poderá ser considerada deficiente mental daqui a 100 anos" (idem, 2003, p.81).

Uma das razões desse aumento, de acordo com a pesquisa, seria a de que os equipamentos eletrônicos estariam ajudando a formar sujeitos com habilidades múltiplas, ou seja, atividades como mexer no computador ou mesmo trocar o canal de televisão atuariam como exercícios para a memória e, por isso, essa geração conseguiria manter atenção em várias coisas ao mesmo tempo.

Essa tem sido uma interpretação usual da maioria dos autores que abordam a temática da Geração Digital (Prensky, 2001; Tapscott, 2009). O que se houve da maioria dos pais é que seus filhos aprendem muito mais rápido do que eles, ou seja, algo que os integrantes das gerações anteriores demorariam horas para aprender, os jovens da Geração Digital têm aprendido em cinco ou 10 minutos. É possível questionar afirmações desse tipo, visto que, a meu ver, o que os jovens dominam hoje são outros mecanismos e esses sim são mais velozes.

$\mathrm{Na}$ vertente mais pessimista, há grupos de especialistas afirmando que nosso cérebro estaria sendo alterado devido ao uso exacerbado das tecnologias. Segundo reportagem veiculada na revista Época (31 de Outubro de 2011) intitulada A internet faz mal ao cérebro? o autor Mark Bauerlein (2009), escritor da obra The dumbest generation: How the Digital Age Stupefies Young Americans and Jeopardize Our Future (ainda sem tradução para o português) afirma que "em vez de mentes juvenis inquietas e repletas de conhecimento, o que vemos nas escolas é uma cultura anti-intelectual e consumista, mergulhada em infantilidades e alheia à realidade adulta" (Época, 2011, p.79). Ele acredita que, imersas a partir das influências digitais, essas novas gerações estão sendo formadas por sujeitos narcisistas e despreparados para pensar em profundidade. Bauerlein (2009) sugere que aspectos como a desatenção e a dispersão fazem com que os mais jovens, acostumados à leitura de textos breves e pobres em termos estilísticos, 
produzam pensamentos simplistas e sem complexidade. Essa ideia tem sido articulada por inúmeros autores, entre eles Nicholas Carr, jornalista americano e citado na matéria da Revista Época. Ele lançou o livro A Geração Superficial: o que a internet está fazendo com os nossos cérebros, e afirma que devido ao uso constante da internet e dos mecanismos de buscas virtuais, a leitura online, cheia de hiperlinks, poderia estar causando dificuldade na concentração em leituras que exigem mais atenção. Segundo o mesmo autor, a utilização das tecnologias digitais estaria, até mesmo, alterando o nível bioquímico dos nossos cérebros.

A imersão em um estilo de vida completamente cercado pelas tecnologias e marcado pelas novas práticas em torno de smartphones, redes sociais e jogos de videogame, sublinham o tom celebratório, ambivalente, polarizado e inédito conferido à Geração Digital. De um lado se dispõe toda uma argumentação mais pessimista sobre o impacto das tecnologias, alegações que têm aferido às tecnologias um poder "determinista" em prejudicar o desenvolvimento moral, cognitivo ou mesmo social de crianças e jovens. Do outro lado estão dispostos os "defensores" da Geração Digital - utilizando argumentos de ordem igualmente determinista - ao sugerir que a relação dos jovens com as tecnologias tem proporcionado novas formas de aprendizagem, aumento do QI (quociente de inteligência), entre outros benefícios. Ambas as perspectivas, utópicas e polarizadas, têm sido cada vez mais popular nos estudos sobre alfabetização, aprendizagem, ensino etc.

\section{CONSIDERAÇÕES FINAIS}

$\mathrm{Na}$ atualidade, há muitas terminologias para se referir a uma geração imersa nas mídias digitais - Geração Digital (TAPSCOTT, 1998; 2009), Nativos Digitais (PRENSKY, 2001) - entre muitas outras. Não quer dizer simplesmente que um vocabulário todo novo surgiu para falar de uma determinada geração, mas que, nesse sentido, uma nova importância foi dada às tecnologias digitais nos ambientes de trabalho e familiares, nas escolas, nas universidades - e, por isso, as tecnologias também têm afetado a vida dos jovens. Ou seja, cada vez 
mais tais expressões entram em circulação nos meios jornalísticos, acadêmicos, escolares, publicitários, instaurando condições para que se possa pensar a produção de uma geração atrelada ao mundo digital. A importância dessas denominações não é simplesmente uma mera justificativa. É preciso considerálas como constitutivas de saberes que pretendem, segundo Rose (1998), produzir conhecimento sobre os sujeitos.

Por um lado, características como o aumento do desenvolvimento cognitivo, habilidade para utilizar diversas mídias ao mesmo tempo, aumento no nível de Q.I, velocidade. Por outro, perda da memória, dificuldade para relacionamentos, falta de concentração. O que parece ser unanimidade entre algumas obras acadêmicas e as representações midiáticas é que os sujeitos jovens estão sendo afetados pelas novas tecnologias e que a habilidade (positiva e negativa) para coordenar várias mídias ao mesmo tempo também os distinguiria de outros sujeitos. Vale destacar o quanto especialistas da Educação, Medicina, Administração, Marketing, Psicologia, Sociologia, vêm sendo acionados a falar sobre tal relação, surgindo representações que inspiram, fomentam e prescrevem regras de conduta, criando certa regulamentação a respeito de uma população específica (ROSE, 1998). Os grupos de profissionais, cada um com seus conhecimentos e convicções, vão se dedicando a classificar, moldar e instituir novos saberes, implicados justamente em produzir objetos do conhecimento.

Essas representações dos sujeitos pertencentes à Geração Digital se prestam a dar sentido às relações entre os jovens e as tecnologias, promovendo, de alguma forma, inteligibilidade sobre esses sujeitos. Quando as reportagens acompanham o dia a dia dos jovens ou mesmo quando entrevistam seus pais e professores, quase sempre, comoauxílio de especialistas (edas obras acadêmicas) que fazem diagnósticos dessas relações de simultaneidade, as representações arroladas pelas revistas acabam refletindo a condição de imediatismo como uma possível "nova" sensibilidade que rege a vida contemporânea.

É neste sentido que a velocidade pode ser percebida como um fenômeno recente. Corroborando essa ideia, concordo com Bauman (2001) ao afirmar que 
hoje, os fluxos de capital e as pessoas viajam com leveza - apenas com a bagagem de mão, que inclui pasta, telefone celular e um computador portátil. Isso permite aos "passageiros" embarcar e partir de qualquer ponto, sem precisar demorar-se em qualquer lugar além do tempo necessário. A velocidade parece imperativa aos jovens e o "antigo lema carpe diem adquiriu um sentido totalmente diferente e leva uma nova mensagem: colha seus créditos agora, pensar no amanhã é perda de tempo" (BAUMAN, 2003, p.209).

\section{REFERÊNCIAS}

BAUERLEIN, Mark. The Dumbest Generation: How the Digital age Stupefie Young Americans and Jeopardizes Our Future. Tarcher: Los Angeles, 2009.

BAUMAN, Zygmunt. Modernidade líquida. Trad. Plínio Dentzien. Rio de Janeiro: Zahar, 2001.

BAUMAN, Zygmunt. Comunidade: a busca por segurança no mundo atual. Trad. Plínio Dentzien. Rio de Janeiro: Zahar, 2003.

BAUMAN, Zygmunt. Identidade: entrevista a Benedetto Vecchi. Trad. Carlos Alberto Medeiros. Rio de Janeiro: Zahar, 2005.

BAUMAN, Zygmunt. 44 Cartas do Mundo Líquido Moderno. Trad. Vera Pereira. Rio de Janeiro: Zahar, 2011.

BUCKINGHAM, David. Crescer na Era das Mídias Eletrônicas. Trad. Gilka Girardello e Isabel Orofino. Rio de Janeiro: Loyola, 2007.

CARR, Nicholas. A Geração Superficial: o que a internet está fazendo com os nossos cérebros. Rio de Janeiro: Agir, 2011.

COSTA, Marisa Vorraber. Sujeitos e subjetividades nas tramas da linguagem e da cultura. In: CANDAU, V. (org.) Cultura, linguagem e subjetividade no ensinar e aprender. Rio de Janeiro: DP\&A editora, 2000, p. 29-45.

FEIXA, Carles; LECCARDI, Carmen. O conceito de geração nas teorias sobre a juventude. Sociedade \& Estado, Brasília, Vol.25 n.2, mai - ago 2010. 
HALL, Stuart. The work of representation. In: HALL, Stuart (org) Representation: cultural representations and signifying practices. London: Sage Publications, 1997.

HALL, Stuart. Identidade cultural na pós-modernidade. Trad. Tomaz. T. Da Silva e Guacira Louro. 2 ed. Rio de Janeiro: DP\&A Ed., 2004.

JAEGER, Hans. Generations in History: Reflections on a Controversial Concept. In: History and Theory, Vol.24, No. 3, 273-292, 1985.

MANNHEIM, Karl. O problema sociológico das gerações" [tradução: Cláudio Marcondes], In Marialice M. Foracchi (org), Karl Mannheim: Sociologia, São Paulo, Ática, 1982 p. 67-95.

PRENSKY, Mark. Digital natives, digital immigrants, part I. On the Horizon. Lincoln: NCB University Press, v. 9, nº 5, 2001.

PRENSKY, Mark. Digital natives, digital immigrants, part 2. On the Horizon. Lincoln: NCB University Press, v. 9, n 5, 2001.

ROSE, Nikolas. Governando a alma: a formação do eu privado. In: SILVA, Tomaz. T. (Org.) Liberdades Reguladas. Petrópolis: Vozes, 1998.

TAPSCOTT, Don. Growing up digital: the rise of net generation. New York: McGraw-Hill, 1998.

TAPSCOTT, Don. Grown up digital: how the net generation is changing your world. New York: McGraw-Hill, 2009.

\section{Reportagens publicadas na Revista Época}

CAIRO, Alberto; MOON, Peter; SORG, Leticia. A internet faz mal ao cérebro? Revista Época, outubro de 2011, n 663, p. 76-84.

MELLO, Katia; VICÁRIA, Luciana. Os Filhos da Era Digital. Revista Época, setembro de $2007, n^{\circ} 486$, p. 82-94.

VEIGA, Aida. Infância Hi-Tech. Revista Época, novembro de 2003. n² 285, p. 70-82. 
dof $10.48209 / 978-65-89949-24-5$

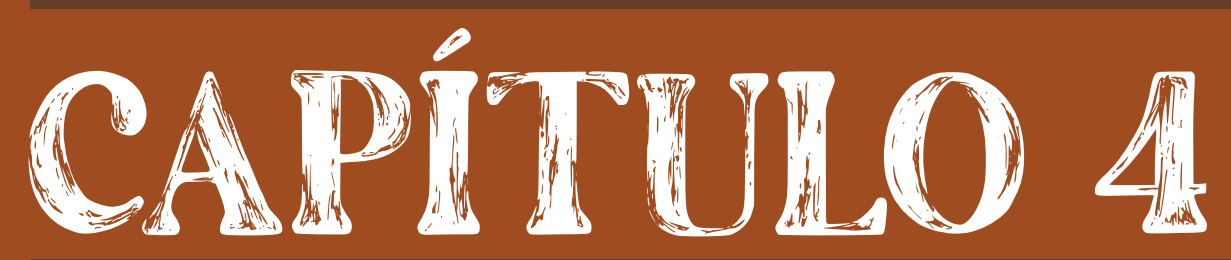

\section{TECNOLOGIAS \\ DIGHAIS E EDUCAÇÃ O: DESENVOLVMMENTO DE JOGO PARA CRIANÇAS COM TRANSTORNO DO BSPECIRO DO AUHISMO}

Keila Aparecida Duarte Rufino Vanessa Matos dos Santos Valéria Peres Asnis 


\section{INTRODUÇÃO}

O desenvolvimento das sociedades contemporâneas tem sido marcado, principalmente a partir da revolução informacional (LOJKINE, 2002; GAMBOA, 2002), pela valorização de bens imateriais como dados, informações etc. De acordo com essa nova lógica, interessa ter acesso à maior quantidade possível de dados acerca de uma população ou agrupamento social com foco não apenas a promover vendas (como ocorria até a década de 1980), mas sobretudo, relações, vínculos e também mecanismos de domínio e consagração de poder (CANCLINI, 2020). Por outro lado, este mesmo cenário abre novas perspectivas educativas, sociais, econômicas por meio da ressignificação das tecnologias digitais para além de meros bits. Nesse sentido, os processos de aprendizagem humana podem ser potencializados não apenas com o uso das tecnologias digitais em si, mas também pelas metodologias inovadoras delas oriundas ou por elas suportadas. Nessa perspectiva, a escola, por exemplo, pode se tornar um local mais inclusivo, aberto, lúdico e permeável ao seu entorno.

Partindo desta discussão inicial, este capítulo apresenta a articulação entre Educação, Tecnologias e Comunicação para o desenvolvimento de Adivinha - um jogo digital voltado para crianças com Transtorno do Espectro do Autismo (TEA). O protótipo do jogo, formulado por Rufino (2020), pode ser acessado gratuitamente por meio do link: https://play.google.com/store/apps/details?id=com. UniversidadeFederaldeUberIndia.Adivinha

\section{EDUCAÇÃO NO MUNDO CONTEMPORÂNEO}

No Brasil, tanto o acesso quanto a permanência na escola e o atendimento educacional especializado para os alunos com deficiência são assegurados por leis como: Lei de Diretrizes e base - LDB (BRASIL,1961) e a Constituição Federal de 1988 (BRASIL, 1988). As políticas públicas da educação especial caminham numa perspectiva inclusiva, fundamentadas pela resolução da Declaração de Salamanca que, de acordo com Barretta e Canan (2012, p.8), "[...] demanda que 
os Estados assegurem que a educação de pessoas com deficiência seja parte integrante do sistema educacional" - como um meio de garantir a inclusão desses alunos. A Organização Mundial de Saúde (OMS) defende que há em torno de 70 milhões de pessoas com autismo no mundo, o que corresponde a um caso para cada grupo de 170 pessoas. Entretanto, centros de controle, como o Centers for Disease Control and Prevention (CDC), demonstram que estes números podem ser bem maiores, chegando à proporção de um caso para cada grupo de 54 pessoas $^{6}$. Seguindo a tendência mundial, também nas escolas brasileiras o número de alunos com o TEA tem aumentado e, portanto, a elaboração de estratégias inovadoras que viabilizem o desenvolvimento desses alunos no Atendimento Educacional Especializado (AEE) se apresenta como oportunidade de ampliar as formas de aprendizagem.

O TEA se caracteriza por determinadas condições que afetam e comprometem, em diferentes graus, o comportamento social, a comunicação e a linguagem, sendo os interesses restritos e repetitivos e déficit em atenção compartilhada algumas das muitas características do transtorno. Segundo o DSM-5 (2014), os sujeitos acometidos pelo transtorno possuem comprometimentos de ordem qualitativa e quantitativa.

Assim, ideias inovadoras que visam o desenvolvimento das potencialidades das crianças com autismo são muito importantes. O uso de recursos tecnológicos, como jogos digitais, pode ser uma estratégia a ser utilizada na aprendizagem. Estudos conduzidos por Prensky (2012, p. 36) demonstram ser assertivo o uso desses jogos na aprendizagem pela motivação e eficácia no aprendizado, uma vez que "[...] acrescentar diversão ao processo não apenas fará que a aprendizagem e o treinamento se tornem muito mais agradáveis e envolventes, mas também os tornará muito mais eficazes".

No que se refere às potencialidades dos jogos especificamente para crianças com autismo, Barbosa (2008; 2009), Santarosa e Conforto (2015), defendem a utilização da tecnologia para a melhora da aprendizagem e inclusão desses

$6 \quad$ https://www.cdc.gov/ncbddd/autism/addm.html 
alunos. Seguindo esta mesma vertente, Passerino (2005, p. 304), em pesquisa sobre o uso de computador com pessoas com autismo, constatou a importância de ações mediadoras junto com o trabalho com a tecnologia. Para a autora, "[...] o ambiente digital de aprendizagem é constituído pelos elementos tecnológicos, humanos e metodológicos, incluindo todo o contexto histórico [...]".

É certo, portanto, que o uso de recursos tecnológicos digitais - aqui traduzidos pelos jogos digitais - mobilizam diferentes aprendizados e contribuem para a aquisição do conhecimento e de conquistas de habilidades sociais das crianças com TEA. Na realidade os jogos, por si, já mobilizam aprendizagens distintas de forma geral. Interessa-nos, portanto, compreender de que forma isso ocorre e, na sequência, mapear de que forma tais potencialidades se processam no caso da criança com TEA.

\subsection{Jogos Digitais e aprendizagem}

Partindo do conceito de tecnologia como criação do homem diante de uma necessidade, entende-se que, na contemporaneidade, dados os constantes desafios vivenciados pela humanidade, a presença da tecnologia tem sido cada vez mais evidente em diferentes cenários. As tecnologias estão intimamente ligadas ao movimento de mudança na cultura que, por sua vez, está em constante movimento.

Dessa forma, os aparelhos tecnológicos e as atividades que se desenvolveram com eles podem ser considerados como propulsores de modificação na cultura. Um exemplo disso são os jogos digitais (PETRY, 2016). Entretanto, quando é enfatizado algum aspecto do jogo digital, é necessário se ater ao fato de que o objeto jogo precede o jogo digital. Isso significa que a plataforma (o suporte) que sustenta o jogo é que tem natureza digital. Os elementos básicos do jogo, no entanto, se mantêm, posto que [...] regras, conflitos, objetivos, definição de pontos e tomadas de decisões são elementos constituintes da vida humana em geral (PETRY, 2016, p. 25). 
Os jogos digitais educacionais são definidos por vários elementos presentes nos jogos em geral, mas diferem por apresentarem objetivos educacionais bem definidos (RAMOS, LORENSET; PETRI 2016). Elementos como objetivos, regras, interação, desafio e competição auxiliam a aprendizagem e o desenvolvimento das habilidades cognitivas dos jogadores e estão presentes nos jogos educacionais (digitais ou não) (PRENSKY, 2012).

Os jogos digitais podem ser vistos como uma estratégia promissora no processo de aprendizagem na Educação Especial, com grande potencial na intervenção pedagógica, uma vez que "[...] o ponto de partida é identificar a necessidade ou a queixa para, então, estruturar uma intervenção que contemple o jogo digital (PEREIRA-GUIZZO, 2016, p. 272). Assim, considerando o jogo digital como um produto cultural contemporâneo que tem sido utilizado no entretenimento e na aprendizagem, a elaboração de um jogo voltado a atender as demandas da criança com autismo se torna uma estratégia pedagógica inovadora, capaz de proporcionar um "[...] intervalo da vida cotidiana" (HUIZINGA, 1993, p. 12), propondo estímulos voltados a despertar o interesse e a aprendizagem do aluno com autismo.

\section{EDUCAÇÃO INFANTIL E TEA}

A primeira infância, fase que vai desde o nascimento até os 6 anos de idade, segundo o Marco Legal da Infância, se caracteriza por um período em que, além dos cuidados físicos e emocionais que a criança necessita e tem direito a receber, também é um período significativo com relação à aprendizagem (BRASIL, 2016). É nessa etapa da vida que o sistema nervoso se desenvolve. Por meio das experiências vivenciadas, as crianças acumulam aprendizagens que no cérebro são denominadas conexões neurais. Quanto mais estímulos são oferecidos nas brincadeiras e atividades proporcionadas aos pequenos, mais conexões cerebrais (WAJNSZTEJN, 2009). Segundo Wajnsztejn (2009), o ápice das conexões cerebrais na infância acontece por volta dos 2 anos de idade. Para Saldanha (2014, p. 54), nessa fase da primeira infância, fica “[...] muito explícita 
uma correlação entre o desenvolvimento normal e autista". Tomasello (2019, p. 107) ainda afirma que, aos 9 meses de idade, os bebês começam a realizar um número expressivo dos chamados comportamentos de atenção compartilhada, de crucial importância no processo de aquisição da linguagem e socialização e que está ausente em grande parte das crianças com autismo, pressupondo "algum tipo de déficit biológico nessa habilidade". Portanto, pode-se afirmar que o autismo é, em grande medida, a consequência de um transtorno importante de processos críticos do desenvolvimento, que tem lugar na criança com desenvolvimento típico.

A Organização Pan-Americana de Saúde adverte que "A intervenção durante a primeira infância é importante para promover o desenvolvimento ideal e o bem-estar das pessoas com transtorno do espectro autista." (ORGANIZAÇÃO PAN-AMERICANA DA SAÚDE, 2017). Sabendo que, de maneira geral, os cuidados e o estímulo são essenciais para o bom desenvolvimento na primeira infância, cuidar e proporcionar situações de aprendizado direcionadas à criança com TEA se torna algo ainda mais importante. Na Educação Básica, a primeira etapa é denominada de Educação Infantil e tem por finalidade o desenvolvimento integral da criança até os 5 anos em seus aspectos físico, psicológico, intelectual e social, complementando a ação da família e da comunidade (LDB, Seção II, artigo 29). De acordo com as Diretrizes Curriculares Nacionais da Educação Infantil: "As práticas pedagógicas que compõem a proposta curricular da educação infantil devem ter como eixos norteadores as interações e a brincadeira[...]." (BRASIL, 2010, p. 25).

Cipriano e Almeida (2016, p. 79) percebem nas brincadeiras e nos jogos momentos propícios para aprender a se comunicar e relacionar. No que tange à criança com autismo, asseveram que as brincadeiras "[...] são formas espontâneas de intervenção nas demandas, déficits e dificuldades apresentadas por elas". Em vista disso, a educação infantil representa um tempo de aprendizagem a partir das brincadeiras e da convivência com os pares. Para Camargo e Bosa, "[...] fica evidente que crianças com desenvolvimento típico fornecem, entre ou- 
tros aspectos, modelos de interação para as crianças com autismo, ainda que a compreensão social destas últimas seja difícil" (CAMARGO; BOSA, 2009, p. 68). Isso significa, portanto, que as brincadeiras seriam o mecanismo pelo qual a criança com o transtorno recebe informações comportamentais que servem como modelo para uma possível imitação dos pares. A imitação, por sua vez, faz parte do processo de aprendizagem, seja da linguagem ou relacionados ao aprendizado escolar. Para Vigotski (2018), o ato de imitar nunca é reproduzido da maneira como aconteceu, algo novo é acrescentado.

Assim, crianças com ou sem o transtorno interagem e desenvolvem habilidades sociais pelo brincar, que a partir de regras e imitação conduzem ao caminho da socialização. Camargo e Bosa afirmam que a competência social é "[...] um conjunto de comportamentos aprendidos no decurso das interações sociais, sobretudo na interação com pares" (CAMARGO; BOSA, 2009, p. 66). De acordo com as autoras, é nas trocas favoráveis entre as relações sociais que se desenvolve a linguagem e o desenvolvimento cognitivo.

No contexto infantil, a brincadeira se torna um importante promotor de linguagem, cognição e socialização para todas as crianças, mas principalmente para a criança com TEA. Chiote (2015) evidencia a importância do brincar para a criança com o transtorno, levando em consideração a interação entre os pares; contudo, salienta sobre a intervenção do adulto, que deve ser uma espécie de moderador de relações, ajudando na tradução dos sentimentos, na compreensão e utilização de regras e valores sociais que conduzem à convivência social. Para a autora, a "[...] brincadeira torna-se uma possibilidade de desenvolvimento da criança com autismo a partir do investimento dos adultos em seu envolvimento com a prática social específica da infância" (CHIOTE, 2015, p. 96).

A criança com autismo não tem capacidade de fazer representações mentais sobre as representações mentais dos outros, ou seja, não consegue entender o que o outro sente (RIVIĖRE, 1995), não possuindo a capacidade mental de interpretar as ações de terceiros (BEYER, 2002), ou seja, são crianças que não "entendem as outras pessoas como agentes intencionais iguais a elas próprias 
(TOMASELLO, 2019, p. 96). Considerando os sujeitos em estudo, crianças entre 4 e 5 anos com TEA, e o espaço da escola como contexto que permeia as relações que elevam o aprendizado e o desenvolvimento, Mattos e Nuernberg (2011) atestam o valor da mediação nas trocas sociais no contexto escolar e em estudos sobre inclusão de crianças com autismo. Os autores revelam que "A brincadeira se configurou como um canal comunicativo em que trocas sociais passaram a ser realizadas no contexto escolar." (p. 138). Assim sendo, o jogo e a brincadeira possibilitam o trabalho com a criança com autismo, que carece de estímulos nas áreas da linguagem, da criatividade e da socialização.

Assim sendo, o jogo e a brincadeira possibilitam o trabalho com a criança com autismo, que carece de estímulos nas áreas da linguagem, da criatividade e da socialização. Tendo em vista a discussão acumulada, apresenta-se, na sequência, o detalhamento metodológico de desenvolvimento do jogo digital Adivinha.

\section{ADIVINHA - DESENVOLVIMENTO DO JOGO DIGITAL}

Partindo do objetivo geral de elaborar uma estratégia pedagógica digital que fosse capaz de propiciar situações motivadoras direcionadas ao desenvolvimento da socialização de crianças com TEA entre 4 e 5 anos, o presente trabalho foi estruturado metodologicamente nas seguintes etapas: 1) desenvolvimento do Game Design Document (GDD) de um jogo digital para estas crianças e 2) desenvolvimento do jogo digital propriamente dito (protótipo).

Para se chegar à elaboração de um jogo que realmente atendesse às demandas da criança com TEA, inicialmente recorreu-se a uma pesquisa bibliográfica que destinou a relacionar conhecimentos acerca do que é o autismo. Num segundo momento, as pesquisas procuraram por indícios que levassem a aproximações de como acontece o aprendizado da criança com TEA, na educação infantil. Concluída a parte de pesquisa, recorreu-se a uma análise de similares com a escolha de jogos digitais direcionados às crianças com autismo e de jogos para crianças da faixa etária do grupo selecionado, sendo observados critérios 
que pudessem ser elencados em seu planejamento. Do montante de jogos, foram selecionados oito para leitura e conhecimento geral e, destes, apenas dois foram separados para análise, por demonstrarem características importantes (destacadas na sequência) para o modelo de jogo digital planejado. São eles: Michelzinho e TEO.

Michelzinho - a metodologia utilizada para trabalhar a socialização, através de modelos de expressões dos sentimentos, com reconhecimento facial no aplicativo;

TEO - a aparência do jogo, o cuidado com os aspectos e as cores. Nota-se que os criadores demonstraram preocupação com o elemento cores na elaboração do jogo. A utilização das PECs (Sistema de Comunicação por Figuras).

Após a análise destes similares, entre jogos digitais voltados para crianças com autismo, sentiu-se a necessidade de explorar também jogos infantis dentro da faixa etária escolhida para o desenvolvimento do jogo, além de jogos direcionados às pessoas com deficiência. Desse modo, ampliou-se o leque de características para se compor a elaboração do protótipo Adivinha. Desse modo, o jogo "Eu sou?", da marca Estrela, que propõe a imitação a partir de figuras colocadas na testa das crianças, se mostrou como um potencializador de ações que colaboram nas habilidades necessárias para a socialização. Para jogá-lo, a criança necessita estar em grupo e expressar-se utilizando seu potencial cognitivo para formular dicas sobre o objeto ou animal que terá que ser descoberto. Esse jogo apresenta imagens que são separadas por categorias: animais, profissões e comidas. Outro jogo que foi utilizado como inspiração desde o início do projeto foi o "Librário", que por meio de cartas com imagens reais apresenta nomes e movimentos utilizados na Libras - Língua Brasileira de Sinais. A ideia de imagens reais num jogo colabora para uma melhor e maior compreensão da realidade. De modo geral, quatro jogos foram utilizados para análise e coleta de características que ajudaram na composição do novo jogo. Na análise dos jogos os seguintes aspectos foram destacados: TEO: cores e designer, Michelzinho: modo como apresentou as expressões dos sentimentos, "Eu sou?" da Estrela: a divisão do 
jogo por categorias e a imitação e por último o Librário: com a ideia de utilizar as imagens reais e pelo fato de a maioria das crianças com autismo possuir uma boa memória visual.

Com as características definidas, o jogo digital Adivinha foi planejado considerando-se a ideia da imitação por imagens e ações, sendo os assuntos separados por categorias. O diferencial foi o uso de vídeos reais com o mínimo de distração, mantendo o foco na ação a ser reproduzida. A tela inicial foi composta de maneira simples e clara, contendo apenas as opções das categorias dos elementos escolhidos separadas por cor. A linha de raciocínio do jogo foi a da socialização, uma das áreas em que a pessoa com autismo apresenta comprometimento. A ideia principal do jogo digital foi a imitação de papéis vividos no dia a dia, como escovar os dentes (higiene), imitar uma galinha (animais) ou reconhecer algumas emoções, como a tristeza (emoções), por exemplo. Por meio do jogo digital Adivinha, além do estímulo à socialização, poderá ser desenvolvida a coordenação motora grossa por intermédio dos movimentos realizados com a imitação dos vídeos.

\subsection{Game Design Document (GDD) - Adivinha}

O Game Design Document aborda todas as etapas de um jogo a ser construído, delineando todo o seu percurso de criação. O objetivo desse tipo de documento é o planejamento do que irá acontecer, sendo de muita utilidade durante a elaboração do jogo. Para enfatizar a importância da mediação, a proposta do jogo contempla necessariamente a interação (e mediação) de um adulto - professor, pai etc. No caso de Adivinha, a estrutura do GDD foi assim estabelecida:

\section{1 - Tela inicial}

A tela inicial apresenta a logo do jogo Adivinha, elaborada com o desenho de um menino. A escolha pela figura masculina se deu pelo número de meninos acometidos pelo autismo ser muito maior do que o de meninas, numa proporção 
de quatro por um, assim como descrito por Rutter (1993) e apresentado em pesquisas mais recentes (BAIO et al., 2014). A cor azul, que pode ser percebida nessa tela e no fundo das demais, foi eleita em função da referência cultural e por ser a cor que representa o autismo. Nessa mesma tela, as categorias que podem ser escolhidas para iniciar são apresentadas: animais, higiene e emoções. Ao clicar na categoria escolhida, o jogador é direcionado para a tela seguinte. No jogo, a escolha das categorias pela pesquisadora se pautou na ideia dos signos que, em uma sociedade, ajudam a transmitir ideias, sentimentos e hábitos.

\section{2 - Tela de opções}

A tela de opções apresenta um conjunto com quatro elementos decorrentes da mesma classe escolhida, ou seja, se a criança escolheu animais, a tela seguinte apresenta opções de animais a serem imitados. Todas as categorias são compostas por um conjunto de quatro elementos dessa mesma classe.

\section{3 - Tela com vídeos}

É composta por vídeos com imitações da opção escolhida. Por exemplo, se foi escolhido o animal galinha, um vídeo com a imitação do animal será exibido. Todas as categorias são compostas por um conjunto de quatro elementos dessa mesma classe e todos os elementos possuem um vídeo correspondente. Como o jogo é uma adivinha, optou-se por não colocar som, pois isso facilita o processo para a criança com TEA (que precisa mobilizar apenas um sentido (a visão) e evita a sobreposição de elementos (que pode ser um fator estressor) para a descoberta.

\section{4 - Tela de conferência}

É composta por quatro imagens reais, correspondentes a cada uma das opções da categoria escolhida. Por exemplo, na categoria animais, são apresentados a galinha, o cachorro, o peixe e o gato. Nessa tela são exibidas as imagens dos quatro animais para que a criança identifique qual foi o escolhido e faça a sua escolha. 


\section{5 -Tela do acerto ou erro}

Esta parte do jogo é composta por duas telas que aparecem conforme o resultado obtido. Se a criança acertou, aparece um emoji feliz, com a palavra: Parabéns! Você acertou!. Se a criança não acertou, aparece um emoji triste, com a mensagem: Ops! Tente outra vez!.

\subsection{Desenvolvimento do jogo}

Para a elaboração do Adivinha, Rufino (2020) se colocou como produtora e criadora do jogo, sendo responsável pela parte conceitual e pela fundamentação teórica, que partiu de pesquisas feitas para conhecer mais acerca da criança com TEA e suas necessidades. Houve a participação de uma designer/artista discente do curso de Designer da UFU, que trabalhou na arte do jogo com criações próprias das imagens, e ainda de um programador, discente do curso de Ciência da Computação da UFU. As imagens utilizadas foram retiradas de bancos de imagens gratuitos da Internet e os vídeos foram feitos pela própria pesquisadora. Para a filmagem, houve o cuidado de escolher roupas que não despertassem a atenção das crianças, e o cabelo foi preso pelo mesmo motivo. O local das filmagens foi organizado para apresentar o mínimo de estímulos possível. A programação do jogo foi realizada na plataforma de desenvolvimento de jogos e aplicativos Unity, com a utilização da linguagem de programação C\#. As imagens a seguir fazem parte da primeira versão do jogo:

Figura 1 - Tela inicial do protótipo do jogo Adivinha

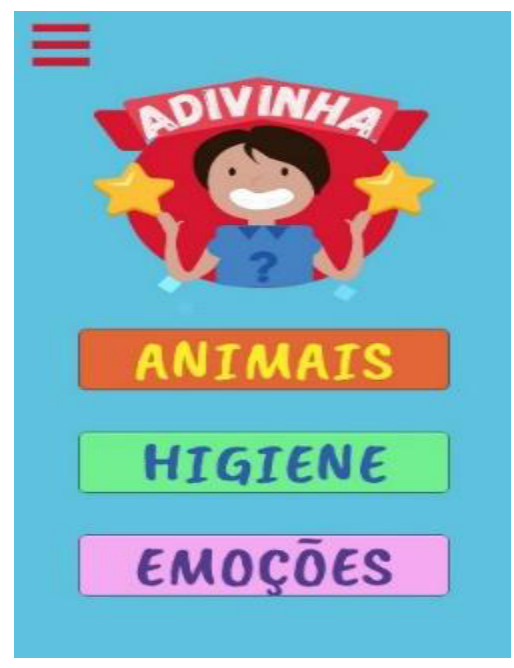

Fonte: Toffoli (2019). 
Figura 2 - Conjunto de telas das categorias escolhidas para iniciar o jogo
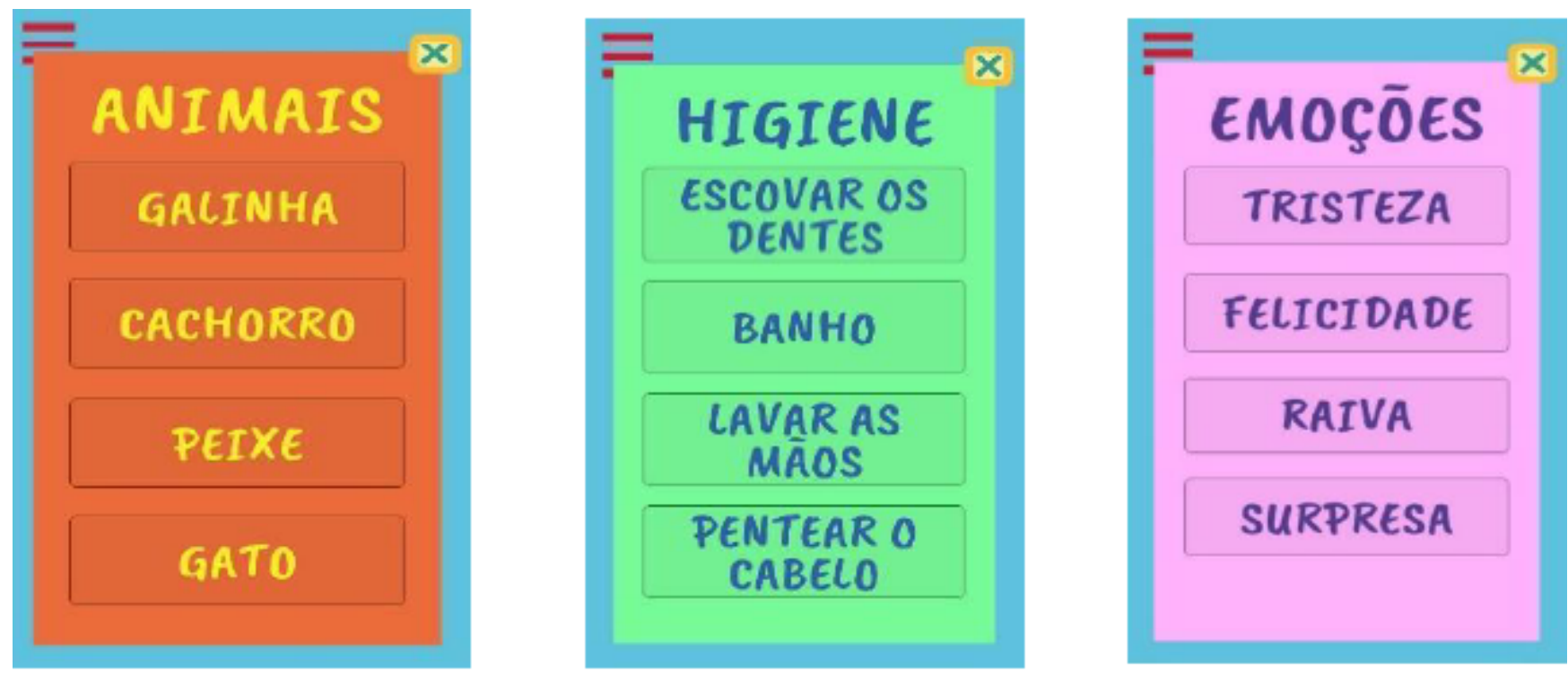

Fonte: Toffoli e Solis (2019).

As imagens apresentadas são capturas dos vídeos feitos para animação da categoria emoções, e foram apresentadas a título de ilustração de uma das etapas do jogo digital Adivinha. As outras categorias também foram elaboradas com vídeos que seguem o mesmo formato e identidade.

Figura 3 - Conjunto de telas da categoria "emoções" (tristeza, alegria e surpresa)

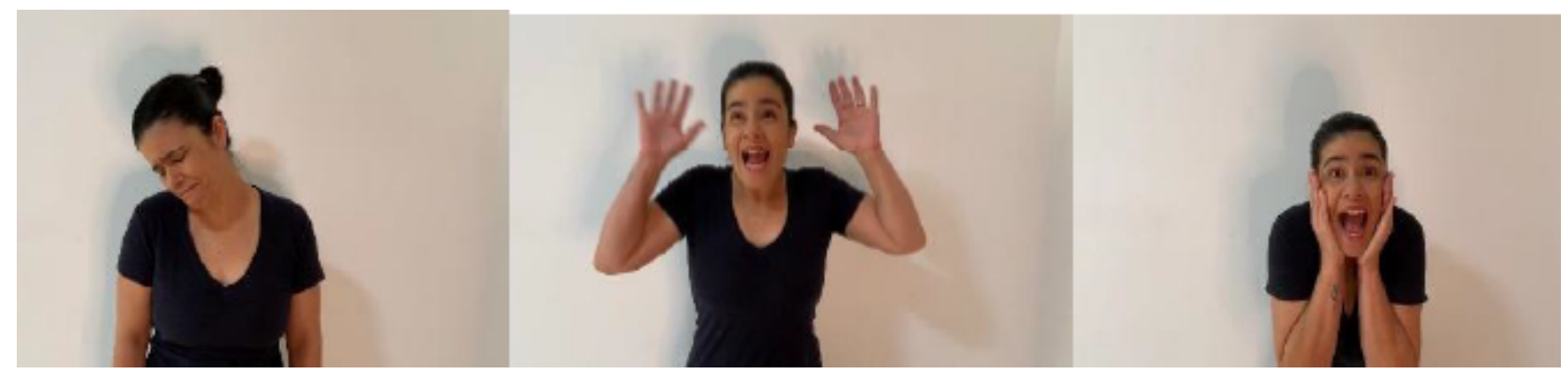

Fonte: Rufino (2020)

\section{CONSIDERAÇÕES FINAIS}

O ponto de partida deste trabalho ocorreu por intermédio da observação do crescente número de crianças com diagnósticos de TEA que estão chegando às escolas. A partir de fundamentação legal, a Educação Infantil se apresenta como 
tempo de desenvolvimento e trocas sociais entre os pares, mediadas pelo professor. A maneira particular como os indivíduos com TEA se comportam demandam estratégias diferenciadas que contribuam para o desenvolvimento desses alunos. Dessa forma, o jogo e a brincadeira possibilitam o trabalho com a criança com autismo, que demanda estímulos nas áreas da linguagem, dos interesses e da socialização. O componente tecnológico foi considerado como um item a ser explorado, devido às representações visuais proporcionadas através dos jogos digitais e que favorecem o aprendizado das crianças com TEA. Os estímulos visuais proporcionados por esses aparelhos são envolventes e positivos no trabalho com pessoas com o transtorno.

Partindo inicialmente do compromisso social e, também articulando conhecimentos oriundos da Educação, Tecnologias e Comunicação, Adivinha se apresenta como uma possibilidade a ser explorada com as crianças entre $4 \mathrm{e}$ 5 anos e que tenham autismo. $O$ jogo digital Adivinha tem uma dinâmica simples que contempla as especificidades das crianças com TEA, contribuindo para o desenvolvimento dos processos de aprendizagem e socialização concomitantemente. Distante de se colocar como algo fechado e finalizado, é importante destacar que, tal como a cultura, o jogo também está em constante movimento e sempre em busca de melhorias.

\section{REFERENTCIAS}

BAIO, Jon. et al. Prevalence of Autism Spectrum Disorder Among Children Aged 8 Years - Autism and Developmental Disabilities Monitoring Network, 11 Sites, United States, 2014. MMWR: morbidity and mortality weekly report, Atlanta, v.67, n.6 p. 1-23, 2018.

BARBOSA, Hugo Fernando Azevedo. Análise do recurso a novas tecnologias no ensino de autista. 2008/2009. Dissertação (Mestrado em Engenharia Informática Sistemas Gráficos e Multimédia) Instituto Superior de Engenharia do Porto, Porto, 2008/2009.

BARRETTA, Emanuele Moura; CANAN, Silvia Regina. Políticas Públicas de Educação Inclusiva: avanços e recuos a partir dos documentos legais. IX AMPED SUL, 2012. 
BEYER, Hugo Otto. A criança com autismo: propostas de apoio cognitivo a partir da "Teoria da Mente". In: BAPTISTA, Claudio Roberto; BOSA, Cleonice. e colaboradores. Autismo e Educação: reflexões e propostas de intervenção. Porto Alegre: Artmed, 2002.

BRASIL. [Constituição (1988)]. Constituição da República Federativa do Brasil de 1988. Brasília, DF: Presidência da República, 1988. Disponível em: http://www. planalto.gov.br/ccivil_03/constituicao/constituicao. Acesso em: 30 jul. de 2021.

BRASIL. Lei $n^{\circ}$ 13.257, de 8 de março de 2016. Brasília, DF: Presidência da República, 2016. Disponível em: http://www.planalto.gov.br/ccivil_03/_Ato20152018/2016/Lei/L13257. Acesso em 30 jul. de 2021.

BRASIL. Secretária de Educação Básica. Diretrizes Curriculares Nacionais para a Educação Infantil. Brasília, DF: MEC, 2010. Disponível em: https://ndi.ufsc.br/ files/2012/02/Diretrizes-Curriculares-para-a-E-I.pdf. Acesso em: 30 jul. de 2021.

BRASIL Lei n 4.024, de 20 de dezembro de 1961. Fixa as Diretrizes e Bases da Educação Nacional. DOU 27/12/1961. Brasília, DF: Presidência da República, 1961. Disponível em: https://www2.camara.leg.br/legin/fed/lei/1960-1969/lei-4024-20-dezembro-1961-353722-publicacaooriginal-1-pl.html. Acesso em: 30 jul. de 2021.

CAMARGO, Síglia Pimentel Höher; BOSA, Cleonice Alves. Competência social, inclusão escolar e autismo: revisão crítica da literatura. Psicologia \& Sociedade, v. 21, 2009, p. 65-74.

CAMARGO, S. P. H., BOSA, C. A. Competência social, inclusão escolar e autismo: revisão crítica da leitura. Psicologia \& Sociedade: V.21, N. 01 p. 65-74, Florianópolis, Jan./Abr. 2009.

CIPRIANO, Monera Sampaio; ALMEIDA, Marcos Teodorico Pinheiro. O brincar como intervenção no transtorno do espectro do autismo. Extensão em Ação, v. 2, n. 11, p. 78-91, 2016.

CHIOTE, Fernanda Araújo Binatti. A interação entre os pares no desenvolvimento do brincar da criança com Autismo. In: OLIVEIRA, Ivone Martins. Autismo e inclusão escolar: percursos, desafios, possibilidades. Curitiba: Editora CRV, 2015.P. 95-112. 
DSM-5- Manual diagnóstico e estatístico de transtornos mentais [recurso eletrônico]: American Psychiatric Association. Tradução: Maria Inês Corrêa Nascimento... et al.; revisão técnica: Aristides Volpato Cordioli ... [et al.]. - 5. ed. Dados eletrônicos. - Porto Alegre: Artmed, 2014.

GARCÍA CANCLINI, Néstor. Ciudadanos reemplazados por algoritmos. transcript Verlag, 2020.

GAMBOA, Silvio Sánchez. Revolução informacional: pontos de vista para o debate sobre a sociedade da informação. Transinformação, v. 9, n. 1, 2012.

HUIZINGA, Johan. Homo Ludens: o jogo como elemento da cultura. São Paulo, Editora Perspectiva S.A, 1993.

LOJKINE, Jean. A Revolução Informacional. 3a. Edição, 2002.

PASSERINO, L. M. Pessoas com Autismo em ambientes Digitais de Aprendizagem: estudo dos processos de Integração Social e Mediação. Tese (Doutorado em Informática na Educação). Programa de Pós-Graduação em Informática na Educação. Universidade Federal do Rio Grande do Sul -RS, 2005.

PEREIRA-GUIZZO, Camila Sousa. Como planejar e avaliar intervenções como jogos digitais na Educação Especial? In: ALVES, Lynn; JESUS COUTINHO, Isa. (Orgs.) Jogos digitais e aprendizagem: fundamentos para uma prática baseada em evidências. Campinas, SP: Papirus Editora, 2016, pp. 269-281.

PETRY, Luís Carlos. O conceito ontológico de jogo. In: ALVES, Lynn; JESUS COUTINHO, Isa. (Orgs.) Jogos digitais e aprendizagem: fundamentos para uma prática baseada em evidências. Campinas, SP: Papirus Editora, 2016, pp. $17-42$.

PRENSKY, Marc. Aprendizagem baseada em jogos digitais. São Paulo. Editora Senac 2012.

RAMOS, Daniela Karine; LORENSET, Caroline Chioquetta; PETRI, Giani. Jogos educacionais: contribuições da neurociência à aprendizagem. Revista X, v. 2, n. 1.2016, 2016. 
RIVIĖRE, Ángel O desenvolvimento e a Educação da Criança Autista. In. COLL, César; MARCHESI, Álvaro.; PALÁCIOS, Jesús (Org). Desenvolvimento psicológico e educação: necessidades educativas especiais e aprendizagem escolar. Vol 3. Tradução. Marcos A. G. Domingues. Porto Alegre, Artes Médicas, 1995. Pp. 234-254.

RUFINO, Keila Aparecida Duarte. Contribuições do jogo para a criança com TEA: Um estudo a partir da perspectiva pedagógica de Reuven Feuerstein. 2020. 168 f. Dissertação (Mestrado em Tecnologias, Comunicação e Educação) - Universidade Federal de Uberlândia, Uberlândia, 2020. Disponível em: http://doi. org/10.14393/ufu.di.2020.96

RUTTER, Michael. Autismo Infantil. In: GAUDERER, Ernst Christian. Autismo e outros atrasos do desenvolvimento: uma atualização para os que atuam na área: do especialista aos pais. Brasília: Coordenadoria Nacional para Integração da Pessoa Portadora de Deficiência - CORDE, 1993. p. 60-82.

SALDANHA, Ana. O Jogo em Crianças Autistas. 1 ed. Lisboa: Coisas de ler, 2014.

SANTAROSA, L. M. C.; CONFORTO, D. Tecnologias móveis na inclusão escolar e digital de estudantes com Transtornos de Espectro Autista. Revista Brasileira de Educação Especial, Marília, v. 21, n. 4, p. 349-366, Out.-Dez., 2015.

SANTAROSA, Lucila Maria Costi; CONFORTO, Débora. Tecnologias móveis na inclusão escolar e digital de estudantes com transtornos de espectro autista. Revista Brasileira de Educação Especial, v. 21, 2015.

TOMASELLO, Michael. Origens culturais da aquisição do conhecimento humano. Trad. Claudia Berliner. - $2^{\mathrm{a}}$ ed. - São Paulo: Editora WMF Martins Fontes, 2019.

VIGOTSKI, Lev Semionovich. Acerca dos processos compensatórios no desenvolvimento da criança mentalmente atrasada. Educação e Pesquisa, v. 44, 2018.

WAJNSZTEJN, R. Desenvolvimento Neurológico e Aprendizagem. In: WAJNSZTEJN, Rubens; WAJNSZTEJN, Alessandra Caturani. Dificuldades escolares: um desafio superável. 2.ed. São Paulo: Ártemis Editorial, 2009, pp.19-32. 
d ol $10.48209 / 978-65-89949-24-6$

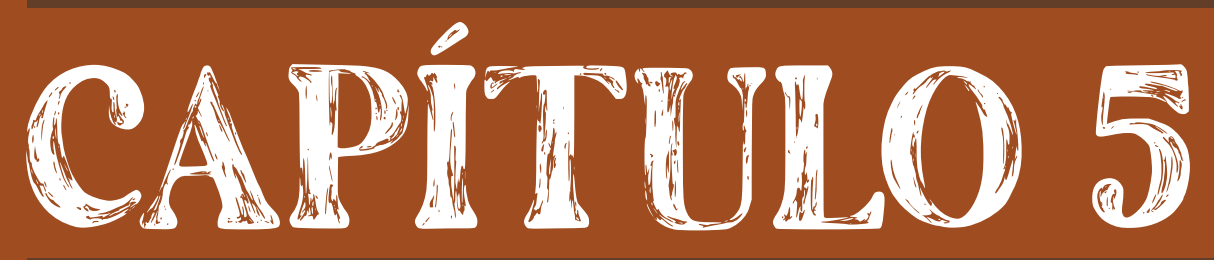

\section{REFLEXÕES SOBRE O USO DAS TEGNOLOGIAS NA INFÂNCIA}

Ana Angélica de Souza Alencar Daniele Dorotéia Rocha da Silva Lima Marcely Barroso Sarges Joaquina lanca Miranda 


\section{INTRODUÇÃO}

As tecnologias têm sido usadas como artefatos que visam aprimorar a qualidade do ensino na educação, proporcionando novos caminhos para ensinar e aprender, com inúmeras metodologias possíveis através das tecnologias. Atualmente, as aulas de todos os assuntos podem ser administradas mesmo em tempos de pandemia, de forma remota. Para que a utilização das tecnologias na educação traga melhorias aos alunos, é necessário que seja planejada de acordo com suas realidades - além de serem utilizadas e orientadas por adultos, de forma significativa, interativa e sensível (INÁCIO; et. al. 2019).

No entanto, o uso das tecnologias enquanto artefato educacional exige um esforço da parte dos professores, que precisam aprender a melhor maneira de usar as tecnologias nas aulas, algo necessário para a efetivação do exercício docente. Embora haja autores que defendem que o uso precoce internet pode trazer grandes malefícios às crianças, ela é vista por outros como um mecanismo que tem como função estimular as habilidades de percepção das crianças, promovendo uma aprendizagem de maior qualidade e interação com outras pessoas e lugares.

A criança contemporânea se constitui pelo desejo de saber e é fortemente influenciada por diferentes mídias. A humanidade convive desde a infância com as visibilidades atrativas das tecnologias, desde o controle remoto, o mouse e o celular. Tais artefatos tecnológicos são extensões do próprio corpo e servem também de estímulos para o desenvolvimento de novas aprendizagens. (INÁCIO et. al., 2019, p. 38).

Conforme Libâneo, (2001, p. 70):

[...] as mídias apresentam-se, pedagogicamente, sob três formas: como conteúdo escolar integrante das várias disciplinas do currículo, portanto, portadoras de informação, ideias, emoções, valores; como competências e atitudes profissionais; e como meios tecnológicos de comunicação humana (visuais, cênicos, verbais, sonoros, audiovisuais) dirigidos para ensinar a pensar, ensinar a aprender, implicando, portanto, efeitos didáticos como: desenvolvimento de pensamento autônomo, estratégias cognitivas, autonomia para organizar e dirigir seu próprio processo de aprendizagem, facilidade de análise e resolução de problemas. 
Levando em consideração que essa geração atual é conhecida como a geração das tecnologias, é difícil para eles se imaginarem longe de um aparelho celular, de uma TV e, principiante, sem o uso da internet. Para muitos autores, os malefícios não são provenientes do uso das tecnologias em si, e sim do exagero e o contato precoce com as tecnologias digitais, pois, a infância é a idade do lúdico, do brincar, correr, imaginar, viver experiências novas a cada momento, criar e recriar. Segundo Moyles (2002, p. 11),

O brincar é sem dúvida um meio pelo qual os seres humanos e os animais exploram uma variedade de experiências em diferentes situações, para diversos propósitos. Considerem, por exemplo, quando uma pessoa adquire um novo equipamento, tal como uma máquina de lavar - a maioria dos adultos vai dispensar a formalidade de ler o manual de ponta a ponta e preferir "brinca" com os controles e funções. Através deste meio, os indivíduos chegam a um acordo sobre inovações e se familiarizam com objetos e materiais: nas descrições do brincar infantil, isso é frequentemente classificado com um brincar "funcional".

Em concordância com a afirmação, pontuamos a importância do brincar no período da infância e, nessa etapa da aprendizagem, o uso das tecnologias com objetivos pedagógicos pode ser benéfico para a criança, ainda mais no atual momento de pandemia que estamos vivendo. Hoje, é através das tecnologias digitais que tem sido possível levar a criança não somente a distração, mas também a atividades de qualidade, mesmo que de maneira remota, possibilitando a aquisição e descoberta de novos saberes. Entretanto, também concordamos que o brincar é algo natural da infância.

Dessa forma, este trabalho tem como objetivo principal refletir sobre o uso da tecnologia na sala de aula e sua contribuição em tempo de pandemia, buscando fazer um paralelo entre autores que defendem prejuízos do uso da internet na primeira infância e outros que defendem seus benefícios.

Para tanto, foi utilizada uma pesquisa bibliográfica com abordagem qualitativa. Segundo Severino (2007, p. 122), a “[...] pesquisa bibliográfica é aquela que se realiza a partir de registro disponível, decorrente de pesquisas anteriores, em documentos impressos, como livros, artigos, teses, etc. [...]". Para acessar esses 
registros, foram utilizadas plataformas virtuais de revistas e acervos científicos, construindo o levantamento bibliográfico desta pesquisa.

\section{CRIANÇA E TECNOLOGIAS}

A brincadeira é algo natural da infância, correr e pegar, pular de pés descalços no chão, contato com a natureza, interação com outras crianças, brincadeiras de faz de conta, onde a imaginação voa livre como pássaro no céu, crianças de joelhos ralados, cabelo suado e ar ofegante de tanto brincar, ansioso por contar as aventuras vividas. Onde estão essas crianças hoje na vida corrida das tecnologias?

Entendemos que o uso das tecnologias para as crianças é fruto das ações no meio em que se está inserido e, principalmente no espaço familiar, já que a criança passa a maior parte do seu dia com a família. Segundo Veen e Vrakking (2009, p. 11),

[...] a geração que nasceu com o mouse na mão. [...] crianças que descobriram o mundo por meio de uma grande variedade de canais de televisão, jogos de computadores, ipods, sites, blogs e telefones celulares, e explora as implicações do comportamento delas para a aprendizagem.

Ao pensarmos que é na fase da infância em que inúmeros desenvolvimentos ocorrem - físico-motor, emocional, cognitivo e social -, percebemos que se trata de diferentes crianças, que podem até ter a mesma faixa etária, mas que não são iguais, não vivenciam as experiências da mesma maneira. Nesse momento, entende-se a importância de um planejamento, até mesmo com relação ao que acessam nas mídias sociais, nos aparelhos eletrônicos. Assim, deve-se planejar uma interação contextualizada, de forma que o tema não seja somente exposto para a criança, mas que busque a interação com situações em que ela vá se descobrindo e descobrindo os fenômenos à sua volta, de forma a produzir sua própria história, conforme afirma Kuhlmann (2010, p. 30).:

é preciso considerar a infância como uma condição da criança. O conjunto de experiências vividas por elas em diferentes lugares históricos, geográficos e sociais, é muito mais do que uma representação dos 
adultos sobre essa fase da vida. É preciso conhecer as representações de infância e considerar as crianças concretas, localizá-las como produtoras da história.

A criança é um sujeito histórico e de direitos, que detém sua própria maneira de aprender, são motivados pela curiosidade, pela interação, pelo movimento. Porém, a cada dia que passa, outro assunto é trazido às discussões sobre a infância: as tecnologias. Nosso século é marcado por grandes mudanças tecnológicas, que a cada dia se tornam mais acessíveis a todas as idades. As DC$\mathrm{NEl} / 2009 /$ trazem essa perspectiva no Art. $4^{\circ}$, afirmando que a criança é sujeito histórico e de direitos que, nas interações, relações e práticas cotidianas que viência, constrói sua identidade pessoal e coletiva, brinca, imagina, fantasia, deseja, aprende, observa, experimenta, narra, questiona e constrói sentidos sobre a natureza e a sociedade, produzindo cultura.

Conforme os Parâmetros Curricular Nacionais da Educação Infantil:

compreender, conhecer e reconhecer o jeito particular das crianças serem e estarem no mundo é o grande desafio da educação infantil e de seus profissionais. Embora os conhecimentos derivados da psicologia, antropologia, sociologia, medicina, etc. possam ser de grande valia para desvelar o universo infantil apontando algumas características comuns da ser das crianças, elas permanecem únicas em suas individualidades e diferenças. (BRASIL, 2006, p. 22).

As tecnologias digitais cada vez mais vem oferecendo inúmeros meios pelos quais pode-se ter uma interação social à distância, o que traz transformações no modo de se relacionar com as pessoas. Muitas crianças acabam se isolando com jogos e vídeos, deixando de viver experiências reais para ser apenas observador das experiências de youtubers. As crianças da atualidade têm um diferencial em relação às crianças que nasceram há 20, 30 anos. Agora, as tecnologias também estão presentes nos brinquedos, os quais, de alguma maneira, produzem um distanciamento das experiências lúdicas que são naturais desta fase, dando lugar à tecnologia materializada em forma do consumismo, com brinquedos cada vez mais atraentes e autônomos, que fazem tudo, impedindo as crianças até mesmo de manterem uma interação com o próprio brinquedo. 
Segundo Oliveira (1986, p. 58):

junto com a diversão que lhe é inerente, o brinquedo é portador de ideias, valores, mensagens identificadoras dos pilares da cultura capitalista. Desde a racionalidade das conquistas tecnológicas, de que são exemplo os brinquedos mecanizados e os eletrônicos, até a reprodução de funções e sensações humanas, como no caso de muitas bonecas, podemos encontrar, na mensagem dos brinquedos, vários ingredientes da ideologia burguesa, que predomina tanto nos países dominantes como nos países subordinados.

Podemos perceber que as tecnologias estão atreladas à vida das crianças desde a sua concepção - fase onde a indústrias investem bastante também -, tornando a criança, desde o berço, uma consumidora. Depois, na fase escolar, existe cada vez mais variedades de materiais escolares, surge a sedução por brinquedos e aparelhos eletrônicos, enlutados pelos marketings nos comerciais de televisão.

Portanto, chegamos a um questionamento sobre esse mundo consumista da atualidade: até que ponto os brinquedos e aparelhos tecnológicos são bons para as crianças? Pois, o brincar vai além do objeto- brinquedo tecnológico, ele permite que a criança participe de um processo criativo, interativo, de "faça você mesmo", lúdico, que propicia experiências humanizadas.

\section{EMBATES NO USO DAS TECNOLOGIAS POR CRIANÇAS}

Há algumas décadas, era mais comum ver mães levando filhos a médicos porque queriam que ganhassem peso, porém, atualmente, temos visto um número altamente alarmante de morbidade infantil por obesidade. Qual tem sido a influência das tecnologias na alimentação e nas atividades físicas das crianças de hoje?

Ainda, podemos perceber que as crianças passam horas excessivas em frente a telas de eletrônicos, por vezes interagindo com pessoas desconhecidas e de lugares distantes, mas com dificuldade de interagir com pessoas reais, que estão à sua volta. As tecnologias têm sim um papel influenciador muito grande e de suma importância na vida das pessoas de todas as faixas etárias hoje, porém, 
é algo que deve ser analisado e ponderado. Até que ponto a utilização das tecnologias pode ser benéfica? Qual a idade ideal para o início do uso das tecnologias, bem como jogos eletrônicos e sites que contenham assunto para adultos? Qual o limite de horas para exposição diante das telas? Como as tecnologias digitais podem ser usadas no processo de desenvolvimento de aprendizagem das crianças?

De Acordo com Inácio et. al. (2019, p. 49):

Há que se considerar os benefícios para o desenvolvimento afetivo, de sociabilidade, da pluralidade de vibrações sensoriais e cognitivo dos vídeos e animações para as crianças. No entanto, o acesso facilitado, excessivo e sem supervisão dos responsáveis pode representar outros riscos para as crianças, como casos de violência e abusos sexuais pela Internet.

Sabemos, também, que seu uso exagerado poderá alterar completamente a rotina e causar consequências como: insônia, estresse, obesidade, irritabilidade e, em alguns casos, quando as complicações se tornam crônicas, precisarem ser tratadas com medicamentos e terapia. Em entrevista à revista on-line Rádio Reverso: as Vozes do Recôncavo, o psicólogo Edson Brito, ao ser perguntado se é normal crianças com menos de cinco já terem acesso ao celular, respondeu:

Não era para ser normal, mas, com essa geração pós-moderna, uma geração muito ocupada, onde os pais não têm mais tempo para os seus filhos, isso infelizmente se tornou normal. Normal era que a criança estivesse brincando, mas não com um aparelho na mão. Normal é que ela ficasse se sujando, caindo, ralando, levantando, brincando de bola, tendo outros afazeres. Com a correria do cotidiano, muitos pais preferem colocar seus filhos na frente da televisão ou dão um celular, porque assim eles vão se distrair, mas, dessa maneira, estão ensinando seus filhos a serem consumistas, não tendo tempo mais de conversar, de brincar.

Uma das principais características da infância é a espontaneidade da criança no pensar, agir, criar e falar. Essas são ações naturais desta fase da vida, principalmente a criatividade e imaginação, porém, com o uso excessivo da tecnologia, esses comportamentos têm sofrido desajustes na infância, o que relata o professor de computação Filho (2011, n.p.): 
No decorrer da minha vida profissional, pelo fato de sempre ter trabalhado na área educacional (com ensino da computação) pude acompanhar diversos exemplos que me mostraram os problemas de crianças que têm uma vida focada em utilizar o computador sem nenhum tipo de restrição. Durante seis anos trabalhei exclusivamente com ensino infantil e fundamental (crianças de 03 a 10 anos) ensinando computação em escolas particulares, e o resultado disso era claramente demonstrado pelo comportamento das crianças, crianças que não possuíam computador ou este tinha o uso controlado pelos pais, possuíam uma integração muito maior tanto com os professores como com os colegas de sala, discutiam suas opiniões e desenvolviam-se de forma muito mais rápida e estabilizada do que crianças que afirmavam utilizar muito o computador. As que os pais permitiam o uso do computador sem nenhuma restrição tinham excelente desempenho na aula de computação, mas não se comunicavam com clareza, não possuíam muitos amigos ou às vezes nenhum, e nas matérias em sala de aula tinham dificuldades de aprendizado e grande dispersão não se concentrando no que era ensinado, não gostavam de participar de brincadeiras em grupo, mostravam má aceitação ao serem repreendidas em caso de realizar algo errado.

Segundo Mattoso (2010, p. 31):

Em pleno século $\mathrm{XXI}$, onde a tecnologia está cada dia mais avançada, as pessoas adquirem doenças e problemas psicológicos frequentes. A tecnologia com os processos de automação leva as pessoas a assumirem uma vida sedentária, já que, a comodidade, rapidez e flexibilidade na aquisição de informação diminuem o esforço das pessoas em buscar fontes alternativas de lazer, trabalho e estudo.

Por outro lado, há autores e estudos que defendem o uso das tecnologias pelas crianças, afirmando que traz certos benefícios a essa faixa etária. Assim, eles defendem que é importante que os pequenos saibam desde cedo manusearem os equipamentos eletrônicos, como celulares e tablets, pois, esses são usados em situações de emergências. Segundo o site Escola Inteligente, em publicação de $2017^{7}$ :

A tecnologia pode aprimorar o raciocínio perceptual. A utilização de determinados jogos em tablets ou computadores contribui para o aumento da percepção da criança em relação às cores e tamanhos, estimulando o desenvolvimento da memória e da sensibilidade.

7 https://escoladainteligencia.com.br/blog/a-tecnologia-como-aliada-no-desenvolvimento-cognitivo-das-criancas/. Acessado em: 03/06/2021. 
Nessa mesma linha de raciocínio, é possível encontrar estudos que avaliam a importância do uso das tecnologias digitais para o cérebro da criança. Segundo o blog Tecnologia na Infância ${ }^{8}$ :

Assim como todo o corpo da criança, o cérebro infantil também está em constante desenvolvimento. Novas conexões são formadas a cada instante, e o modo como essa construção se dá é fundamental para o resto da vida de um ser humano. Sem substituir outras relações, como o contato pessoal e o afeto, jogos e outras atividades interativas são excelentes estimulantes para os pequenos cérebros em desenvolvimento. Ao ampliar as potencialidades do cérebro com mais rapidez, devido aos estímulos fortes e constantes, a criança desenvolve uma mente mais aberta e apta a aprender com facilidade sobre diversos assuntos e de diferentes formas. É um crescimento proporcional: quanto mais se aprende, mais facilidade e interesse se tem pelo aprendizado.

Certamente, as tecnologias têm muitos pontos positivos, tais como: garantir novas formas de estudar; melhorar a preparação para o futuro; desenvolver a capacidade de aprendizado; permitir que a criança produza conteúdos; estimular a concentração e o raciocínio lógico; despertar interesse por novos conhecimentos. Tudo isso foi possível perceber no decorrer das abordagens sobre o uso das tecnologias na infância, porém, sua utilização sem limites pode causar muitos prejuízos às crianças. No entanto, de acordo com Inácio et al (2019, p. 47):

a resolução desse problema não se resume em proibir o uso das tecnologias digitais, mas gira em torno da supervisão, mediação e reflexão no momento de experimentação desses recursos. Só assim a família poderá saber se a criança está reconhecendo os mecanismos ideológicos dessas mídias e desenvolvendo seus interesses, necessidades, habilidades de interação e inteligência emocional

A Base Nacional Comum Curricular (BNCC/2017) evidencia a importância da participação da criança em diferentes zonas de convívio, como família, sociedade e cultura, além de possibilitar a interação com as tecnologias, que aguçam a curiosidade infantil e o surgimento de alternativas para responder às questões que permeiam a infância:

As experiências das crianças em seu contexto familiar, social e cultural, suas memórias, seu pertencimento a um grupo e sua interação com as mais diversas tecnologias de informação e comunicação são fontes que

8 https://happycodeschool.com/blog/tecnologia-na-infancia/. Acessado em: 03/06/2021. 
estimulam sua curiosidade e a formulação de perguntas. O estímulo ao pensamento criativo, lógico e crítico, por meio da construção e do fortalecimento da capacidade de fazer perguntas e de avaliar respostas, de argumentar, de interagir com diversas produções culturais, de fazer uso de tecnologias de informação e comunicação, possibilita aos alunos ampliar sua compreensão de si mesmos, do mundo natural e social, das relações dos seres humanos entre si e com a natureza (BRASIL, 2017, p. 60).

Com isso, a BNCC (2017, p. 40) situa o acesso a mecanismos tecnológicos como um dos seus direitos de aprendizagem e desenvolvimento na Educação Infantil. Segundo o documento, as crianças podem, pela tecnologia:

explorar: movimentos, gestos, sons, formas, texturas, cores, palavras, emoções, transformações, relacionamentos, histórias, objetos, elementos da natureza, na escola e fora dela, ampliando seus saberes sobre a cultura, em suas diversas modalidades: as artes, a escrita, a ciência e a tecnologia.

Reafirmando essa necessidade de a criança ter experiências tecnológicas, os Parâmetros Nacionais de Qualidade da Educação Infantil argumentam que as práticas pedagógicas buscam associar os conhecimentos que as crianças já possuem com aqueles advindos da cultura, arte, ambiente, ciência e tecnologia. Complementando, as Diretrizes Curriculares Nacionais para a Educação Infantil (BRASIL, 2010) orientam que as atividades pedagógicas na Educação Infantil devem possibilitar experiências que envolvam meios tecnológicos e midiáticos, impulsionando as crianças a terem um desenvolvimento completo, idealizado pela Educação Infantil.

\section{AS TECNOLOGIAS COMO ARTEFATO NAS AULAS PRESENCIAIS E REMOTAS}

A criança aprende e compreende o mundo que a cerca através da vivência e de como são dadas essas experiências com o ambiente. A tecnologia permite que as aulas se tornem mais atraentes e mais compreensivas, pois, através de seu uso, por exemplo, através de data show - que reproduzem imagens - e televisores, ou tablets e outros aparelhos, os professores podem facilitar a compreensão dos conteúdos, fugindo das aulas expositivas tradicionais. 
Na educação da criança, essas interações tecnológicas são ainda mais necessárias, pois a criança é atraída pelas cores e movimentos, que podem ser proporcionados pelos aparelhos eletrônicos tanto nas aulas presenciais quanto no momento de pandemia que estamos vivendo desde março de 2020 , em que as aulas nos colégios tiveram que ser suspensas.

Gonçalves e Britto (2020) agregam à nossa discussão um outro olhar diante da pandemia do novo coronavírus, trazendo questionamentos acerca de quais recursos utilizar e de que maneira atingir o público infantil, sabendo principalmente que a BNCC para a Educação Infantil traz o Cuidar e o Educar como base interacionista para o desenvolvimento, de forma a "conviver com outras crianças e adultos, em pequenos e grandes grupos, utilizando diferentes linguagens, ampliando o conhecimento de si e do outro, o respeito em relação à cultura e às diferenças" (BRASIL, 2017, p. 40).

Indo de encontro com a perspectiva da BNCC, as instituições de Educação Infantil começaram a disponibilizar atividades para serem realizadas em casa, com supervisão de um adulto. Assim, percebe-se a introdução de um ensino remoto, que, sendo uma modalidade de caráter emergencial, deve ser vigente por um determinado tempo, almejando a volta para a normalidade assim que os órgãos de saúde permitirem.

Dessa maneira, é exposto, com os diálogos aqui descritos, a importância o ambiente das creches e pré-escolas para as crianças e como o papel do professor é significativo no desenvolvimento infantil, mas, ainda existem barreiras a serem quebradas, como uma graduação que contemple mais disciplinas relacionadas às tecnologias, uma formação continuada e mais políticas educacionais que busquem salientar possíveis acontecimentos, como foi o caso da pandemia a covid-19.

Vale destacar que, para que essas atividades durante o período pandêmico atinjam seu objetivo, a participação da família é fundamental, pois os adultos que irão preparar o ambiente necessário para as inúmeras possibilidades das atividades pedagógicas, além auxiliar a criança durante a execução dos exercícios. 


\section{CONSIDERAÇÕES ABERTAS PARA SEGUIR PENSANDO...}

Durante a elaboração deste trabalho, podemos observar que, diante do momento em que estamos vivendo, as tecnologias digitais têm sido um artefato fundamental para o contato com o mundo, para que as interações sociais permaneçam, mesmo que através das telas dos aparelhos celulares. Na Educação, esse tem sido o meio pelo qual alunos - da Educação Infantil às universidades - têm mantido suas atividades. Dessa forma, entende-se que é possível sim ensinar e aprender, de maneira efetiva, usando as diversas ferramentas que as tecnologias nos oferecem.

Levando em consideração que o ensino remoto foi determinado como algo emergencial, consideramos válida a tentativa de levar as aulas aos lares e, com isso, estimular o vínculo da família com as unidades de ensino, buscando com que nossas crianças tenham momentos de protagonismo.

Fica clara também a necessidade de as tecnologias estarem mais presente na Educação Infantil, mas não como forma de minimizar sua base interacionista, e sim agregando informações e contribuindo para as habilidades, uma vez que a Educação está em movimento com a modernidade e precisa se reformular para atingir o ensino e aprendizagem com melhor qualidade.

Concluímos que, mesmo com todos os benefícios mencionados gerados pelas tecnologias digitais, é evidente a preocupação com os problemas sociais e comportamentais que podem ser gerados por essa nova forma de interação social e cultural, principalmente os que afetam nossas crianças e suas aprendizagens.

\section{REFERENCIAS}

BRASIL. Ministério da Educação. Secretaria de Educação Básica. Parâmetros nacionais de qualidade para a educação infantil. Secretaria de Educação Básica - Brasília. DF v.l; il. 1. Educação Infantil. 2006. 
BRASIL. Ministério da Educação. Secretaria de Educação Básica. Base Nacional Comum Curricular. Versão final. Brasília: MEC/ SEB, 2017.

BRASIL. Ministério da Educação. Secretaria de Educação Básica. Diretrizes Curriculares Nacionais para a Educação Infantil. Brasília: MEC/ SEB, 2010.

FILHO, O. H. B. A infância e a computação. 16, mar. 2011. Disponível em: http:// www.hardware.com.br/artigos/infancia-computacao/. Acesso em 03.06.2021

GONÇALVES, E. R. BRITTO, A. L. F. M. Ensino remoto na Educação Infantil em tempos de pandemia: reflexões acerca das novas formas de ensinar. Revista Práxis, v. 12, n. 1 (Sup.), p. 39-46, dezembro, 2020.

INÁCIO, C. O. et al. Infância e tecnologias: desafios e relações aprendentes. TEXTURA-Revista de Educação e Letras, Canoas, v. 21, n. 46, p. 37-58, 2019. DOI: 10.17648/textura-2358-0801-21-46-4542

KUHLMANN, M. J. Infância e Educação Infantil: uma abordagem histórica. 6. ed. Porto Alegre: Mediação, 2011.

LIBÂNEO, J. C. Adeus professor, adeus professora. São Paulo: Cortez, 2001.

MATTOSO, R. Tecnologia X Sedentarismo. Salada textual, 2010. Disponível em:https://saladatextual.wordpress.com/2010/04/04/tecnologia-X-sedentarismoac. Acessado em 03/06/2021.

MOYLES, Janet R. Só brincar? O papel do brincar na educação infantil. Porto Alegre: Artmed, 2002.

OLIVEIRA, P. S. Brinquedo e indústria cultural. Petrópolis: Vozes, 1986.

SEVERINO, A. J. Metodologia do trabalho científico. 2. ed., rev. e atual. São Paulo: Cortez, 2007.

VENN, W.; VRAKKING, B. Homo Zappiens: educando na era digital. Tradução Vinicius Figueira. - Porto Alegre: Artemed, 2009. 
dol $10.48209 / 978-65-89949-24-7$

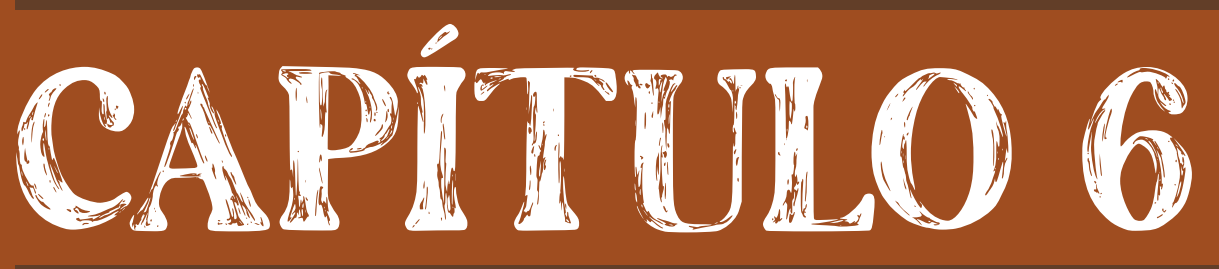

\section{PRÁTHCAS DE ENSHNO MULTIDISCIPLINARES NA EDUCAÇÃO INFANTIL}

Renata Lourinho da Silva Verena Cissa Barbosa de Castro Freitas Gleide Cunha de Souza Maria Nazare dos Prazeres Lopes 


\section{INTRODUÇÃO}

As transformações sociais, econômicas e culturais, como aquelas provocadas pelo avanço acelerado da eletrônica: computadores, celulares, tablets, etc, sendo que a cada dia, tornam-se mais sofisticados, devido ao melhoramento dos softwares e hardwares, e para isso, geralmente as empresas fazem uso da engenharia reversa ${ }^{9}$, isto é, desmontam-se as peças desses eletrônicos, como se fossem 'quebra cabeças', buscando aprimora-lo e assim remontando-os, como é o caso dos computadores tipo Samsung, tem-se dentre outras opções no mercado: o corei2, core i3, core i5, e variam em acordo com a memória e quantidade de armazenamento.

Para além dessas transformações, assistimos no campo das ciências da saúde, evoluções das máquinas de realização dos diversos tipos de exames como aqueles para identificar o câncer, em menor tempo e com maior qualidade das imagens, a exemplo, da ressonância magnética.

No campo cultural, as práticas profissionais de trabalho das comunidades ribeirinhas, por exemplo, também sofreram mudanças, como foi o caso das técnicas de construção e uso do matapi ${ }^{10}$, em que anteriormente, usava-se para a construção comumente as talas de jupati ${ }^{11}$, e fio de timbuí ${ }^{12}$ para fazer as amarrações, neste novo cenário, encontra-se matapis feitos de garrafas petes; de água mineral etc.

Assim, essas constantes evoluções acabam impondo mudanças na maneira de ensinar as disciplinas, exigindo com isso, uma maior autonomia dos professores para os estudos sobre os diversos tipos de fenômenos sociais, o que justifica a necessidade de formações continuadas dos professores, de modo com que as escolas adotem novas formas de trabalhar os conteúdos disciplinares.

9 Engenharia reversa usada para melhoramento de produtos (FARIAS, 2009)

10 Instrumento usado geralmente para a pesca de camarões, podendo assumir outras funcionalidades dependendo do contexto que é utilizado (SILVA, 2019)

11 Jupaty - É feito de talas de Jupaty (Raphia taedigera), um tipo de palmeira extraída na floresta (MORAES, 2005).

12 Timbuí- tipo de cipó extraído da natureza. 
Nesse sentido, a prática da multidisciplinaridade na educação infantil, temática em discussão, bem como a interdisciplinaridade devem "partir da necessidade sentida pelas escolas, professores e alunos de explicar, compreender, intervir, mudar, prever, algo que desafia uma disciplina isolada e atrai a atenção de mais de um olhar, talvez vários" (BRASIL, 1999, p. 88-89).

Pensando nessa problemática, é que a divisão de Educação Infantil, da Secretaria Municipal de Educação- SEMED-CametálPA, propus formações continuadas aos professores que lecionam na educação infantil, atendendo as inquietações desses profissionais, que apresentavam dúvidas, em como trabalhar os conteúdos com as crianças, partindo das orientações da Base comum curricular -BNCC (BRASIL, 2018).

Portanto, o desenvolvimento das formações aos professores da educação infantil, visou orientações para o desenvolvimento de um ensino de qualidade para as crianças, levando em consideração, as medidas de afstamento social provocadas pelo cenário da pandemia do covid 19, bem como, o retorno das aulas presencias, por meio do trabalho de práticas multidisciplinares, utilizando-se da transposição didática do saber (CHEVALLARD, 2009), que questione e problematize, dentre outros, o livro didático, os documentos oficiais como a BNCC (BRASIL, 2018).

Para isso, elaborou-se um plano de formação continuada para os professores da educação infantil em dois dias consecutivos, conectando-se teoria e prática e vice-versa, por meio de um olhar crítico sobre as habilidades e competências presentes em Brasil, 2018, em que questionamos e problematizamos esses campos, tais como: o que se entende por habilidades e competências? Como estão conectados? E assim levantamos o questionamento norteador do processo formativo: Como o professor que leciona na educação infantil pode elaborar seu material de ensino, a partir da problematização da BNCC?

Nesse pensar, o objetivo desse trabalho é mostrar como foi desenvolvido a formação continuada para os professores que lecionam na educação infantil, a 
partir da problematização da BNCC, usando para isso, atividade multidisciplinares.

\title{
PRÁTICAS MULTIDISCIPLINARES NA EDUCAÇÃO INFANTIL
}

A Educação Infantil é umas das etapas do ensino básico essencial para o desenvolvimento cognitivo, emocional e integral da criança, e com isso, entende-se a fundamental importância deste trabalho em parceria com a escola, família e projetos escolares, em prol do desenvolvimento do processo de escolarização (MORAIS et al, 2016). Para além disso, Morais (et al, 2016), ressalta que:

\begin{abstract}
Mas, segundo os autores, para que isso ocorra, faz-se necessário que os educadores reflitam sobre a real função social da escola de educação infantil, que é possibilitam aos alunos situações desafiadoras, de modo que possam ingressar no processo de escolarização de maneira prazerosa e satisfatória (MORAIS et al, 2016, p. 2).
\end{abstract}

No âmbito da formação de profissionais da Educação Infantil, as realizações das palestra foi nessa direção, de propor subsídios para a reflexão da prática docente, com o intuito de conduzi-los de forma gradativa para uma melhor atuação profissional no processo de ensino e aprendizagem, a partir da perspectiva multidisciplinar, no sentido de que a intenção foi alcançar diversos profissionais da educação, temáticas, conceitos e perspectivas com olhares diferentes sobre a mesma temática, possibilitando a compreensão de recursos didáticos que podem contribuir para o processo de ensino dos professores, que para Souza (2007, p. 111), "é todo material utilizado como auxílio no ensino-aprendizagem do conteúdo proposto para ser aplicado pelo professor a seus alunos", bem como, com o trabalho dos docentes e profissionais da educação presentes neste processo, resultando em seu completo êxito.

Para Souza et al (2017), falar de multidisciplinaridade no contexto escolar, remete, ao trabalho interpessoal, que vem sendo amplamente utilizado pelas várias áreas disciplinares e não disciplinares e em diversos níveis de atuação, e caracterizam-se, por meio da interação estabelecida entre seus profissionais, podendo assumir as características multidisciplinares, interdisciplinares, e ainda, 
transdisciplinares. Tonetto e Gomes (2007) conceituam esses termos, e afirmam que "a interação é multidisciplinar quando existem vários profissionais atendendo o mesmo paciente de maneira independente" (p. 89-90).

Condizente com os estudos de Pires (1998) e sob a orientação de Petraglia (1993, p.2),

\begin{abstract}
Muito se ouve falar em multidisciplinaridade, interdisciplinaridade e transdisciplinaridade, no entanto, se buscarmos uma compreensão mais aprofundada deste novo discurso perceber-se-á que a ideia mais discutida e praticada, em geral, é a multidisciplinaridade.
\end{abstract}

Diante do exposto, e considerando o contexto educacional, a multidisciplinaridade, aparenta esgotar-se nas buscas por um trabalho em equipe, pelos docentes, entre as disciplinas, em que cada uma trata de temas comuns sob sua própria ótica, ou seja, de forma isoladas, raras vezes articulam-se, com bibliografias, técnicas de ensino e procedimentos de avaliação (PIRES, 1998). Ainda, Pires (1998) reforça, ao dizer que na multidisciplinaridade as pessoas, no caso as disciplinas do currículo escolar, estudam próximo, mas não integradas.

Tonetto e Gomes (2007) falam da relevância em enfatizar a multidisciplinaridade na escola, pelo fato de ser um local privilegiado e propício para intervenções e construção de propostas de natureza multidisciplinar e, permiti perceber a importância do uso desse tipo de atividades nas áreas educacionais, estabelecendo parcerias com diversos profissionais e áreas de conhecimento, e dessa maneira, promover o entendimento de uma mesma situação, a partir de olhares e perspectivas de vistas diferentes.

Nesse entender, Souza et al (2017) complementa com base nas discussões de D'artibale et al, (2011) que o ambiente escolar é tomado como um lugar de convívio em equipe, que põe os alunos a um contato mais próximo e frequente, resultando com isso, em uma pluralidade cultural e na necessidade de propostas, que possibilitem discussões de diversos temas transversais, tais como: respeito, a ética, a sexualidade, o autocuidado, saúde, entre outros. 
Para tanto, é necessário que a escola ultrapasse os seus métodos tradicionais de ensino dos conteúdos, que estão baseados somente em práticas e ações individuais; ao contrário disso, deve conectar as disciplinas, de modo a favorecer maior (re) significação da prática docente e apropriação dos conteúdos pelos alunos (SOUZA et al, 2017). Até porque, como nos fala (SOUZA et al, 2017), nos últimos tempos a divisão do trabalho industrial, vem exercendo expressivas influências na organização curricular, e entende-se que essa reorganização do trabalho atual, seja flexível com exigência de multifuncionalidade (PIRES, 1998).

\section{METODOLOGIA}

O desenvolvimento metodológico do trabalho consisti em um estudo qualitativo Godoy (1995), em que fizemos reflexões sobre os possíveis temas que poderiam ser tratados pelos palestrantes, de modos a manter a conexão da teoria e da prática e vice versa, integrando com isso, saberes culturais e escolares como possíveis desencadeamentos para a questão norteadora: Como o professor que leciona na educação infantil pode elaborar seu material de ensino, a partir da problematização da BNCC?

Para tentar responder a esse questionamento, fez-se necessário o estudo das práticas e dos saberes, denominado por Chevallard (1999) de praxeologias, que comporta dois blocos, aqueles referentes aos saberes práticos (tarefas e técnicas) e do saber teórico (tecnologia e teoria), que contribuem para o entendimento sobre o que ensinar da BNCC? (Tarefa); como ensinar? (Técnica); para que (tecnologia) e por que ensinar (Teoria)?

Nesse caminhar, a elaboração do plano de formação contemplou esses questionamentos e assim nos dias 12 e 13 de maio de 2021 aconteceu a I Formação dos professores da educação infantil, organizada pela Secretaria Municipal de Educação (SEMED), Departamento Pedagógico (DP), divisão de Educação Infantil, em parceria com a Escola de Formação (e-For), do município de Cametá/ PA. 
A realização da formação foi online transmitida pelo canal do youtube da escola de formação E-for Cametá, e atendeu os protocolos de medidas de afastamento social instaurada pela pandemia da Covid-19.

A partir daí, no primeiro dia da formação, contamos com a palestra do prof. - esp. Diego Matos, explorando o tema: "orientação pedagógica em tempo de pandemia na educação infantil; enquanto no segundo, aconteceram duas palestras a da prof. ${ }^{a}$ Dr. Andréa Matos, abordando "A ação dos novos reformadores e a implementação da BNCC para a educação infantil" e em seguida da prof. a $\mathrm{Ma}$ Verena Cissa Castro, que mencionou o tema: "Sequência didática usando práticas socioculturais para a educação infantil ".

Segue os banners da formação, que foram montados por uma das professoras da escola de formação E-forlCametálPA.

Figura 1: Banner $-1^{\circ}$ dia

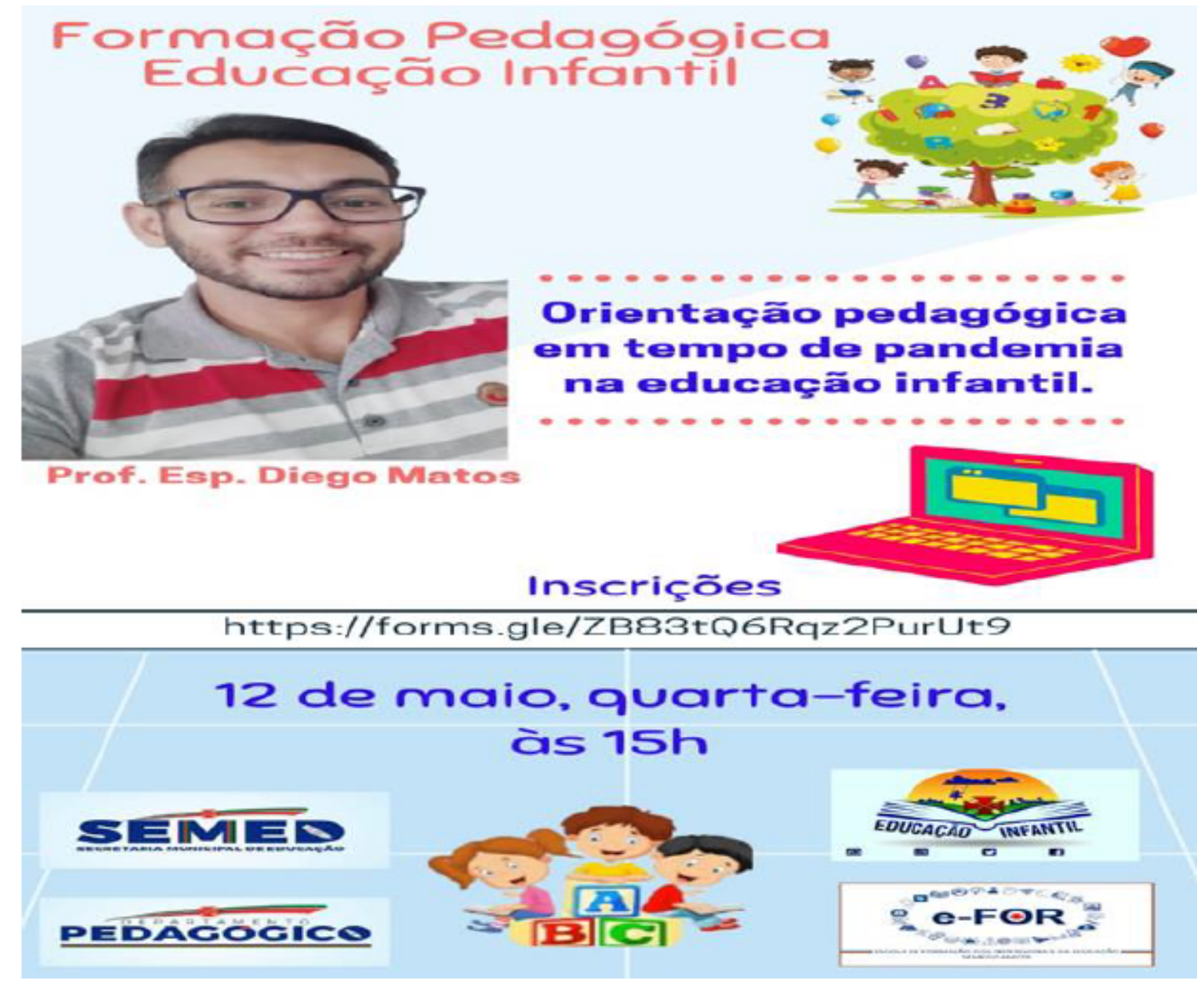

Fonte: Brito, 2021 
Figura 2: Banner-2 dia
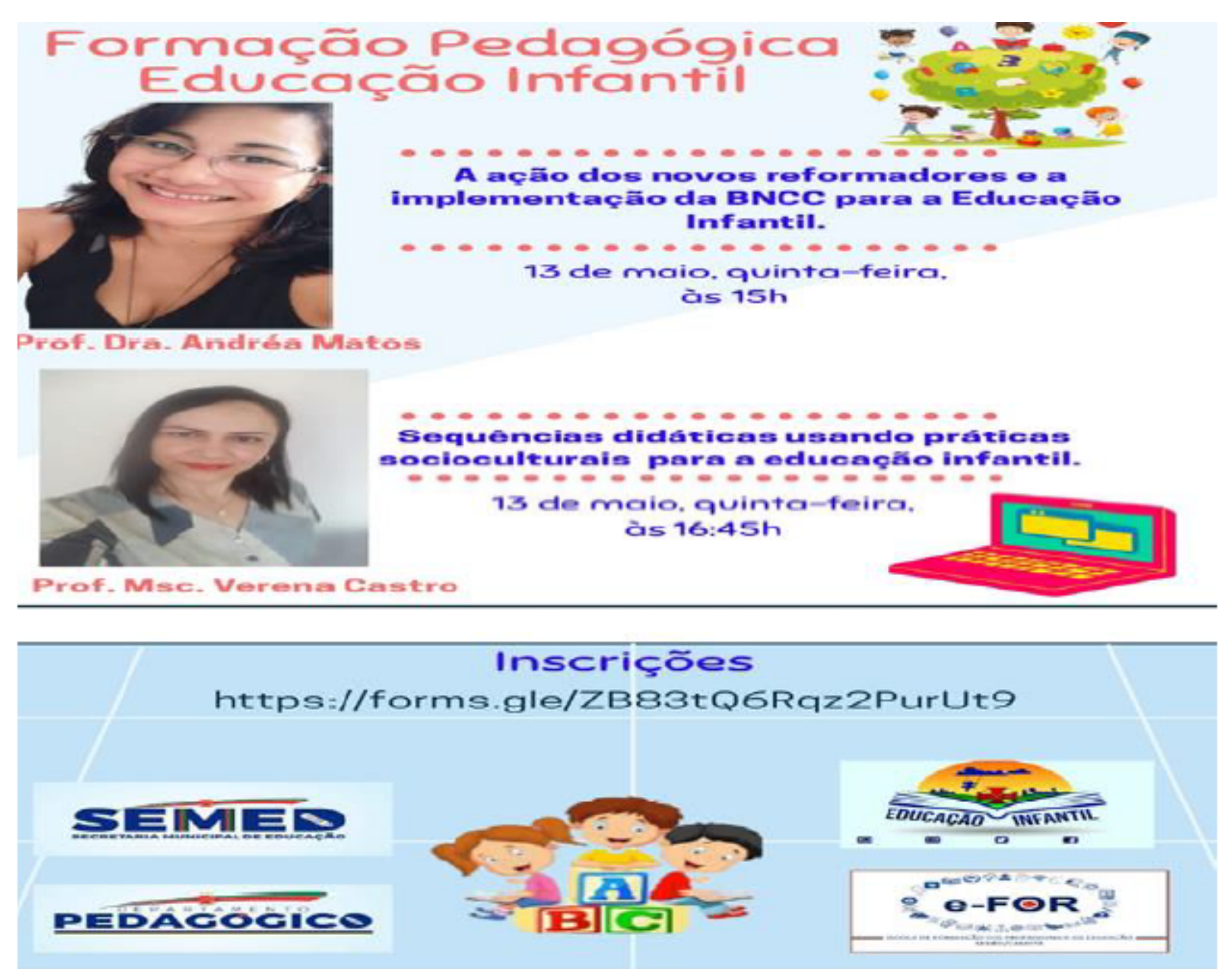

Fonte: Brito, 202

\section{RESULTADOS E DISCUSSÕES}

Como resultados da formação continuada, obtemos:

Da palestra do prof. Esp. Diego, obtivemos 671 visualizações, disponível no link do yutube do canal do E-FOR Cametá: “ (68) PRÁTICAS DE ENSINO MULTIDISCIPLINARES NA EDUCAÇÃO INFANTIL. - YouTube", e ocorreu no dia 12 de maio e abordou como tema "Orientação pedagógica em tempo de pandemia". O mesmo fez uma reflexão a respeito da Base Nacional Comum Curricular na Educação Infantil (BNCC, 2018), esclarecendo alguns pontos como o da organização curricular, campos de experiência, objetivos e aprendizagens a serem vivenciadas pelas crianças. 
Ainda ressaltou sobre a questão dos registros a ser realizados nessa etapa através de relatórios, portifólios, diário de bordo entre outros. Outro aspecto importante que o mesmo abordou, refere-se ao uso de uma linguagem acessível para os cadernos de atividades para a melhor compreensão dos pais, assim como, orientou para a realização de jogos com materiais disponíveis na casa das crianças.

Outro ponto que merece destaque foram os comentários dos professores no chat, que relataram ser muito importante a contribuição do prof. Diego, pois ele mostrou um modelo de plano de aula que veem sendo desenvolvido pelas escolas infantis do município de Ipixuna do Pará, bem como, reforçou a importância do uso do portfólio, diários de bordo, como instrumentos avaliativos tanto para o ensino do professor, quanto para aprendizagem dos alunos.

Também, os educadores mencionaram que na maioria das escolas, do município de Cametá, PA, não se tem coordenadores específicos para atuação na educação infantil. Outro problema se refere ao tipo de celular, que a maioria dos pais possuem, os quais tem pouca memória, o que acaba interferindo para baixar aplicativos educacionais, bem como, o acesso ineficiente de internet.

Além disso, perguntaram sobre: como usar códigos para os planos de aula?, Esse código foi algo inovador para os docentes, então o prof., Diego explicou a construção do código, por meio de um exemplo: Considere que em uma determinada escola, suponhamos que o coordenador pedagógico, reúna 5 professores e seleciona um tema para ambos desenvolverem seus planos de aula, logo o código resultante desse trabalho, vai ser somente um, caso os temas sejam diferentes, faz-se necessário usar códigos distintos para cada temática, levando em consideração os campo das competências e experiências presentes na BNCC (2018).

Portanto, contamos com a participação de mais de duzentos professores que contribuíram significativamente e parabenizaram a troca de conhecimentos que houve, pois o diálogo foi de suma importância para o momento que a educa- 
ção está vivenciando, os problemas, as dificuldades enfrentadas pelos professores e também pelos alunos e família.

Da palestra da prof. Dr. ${ }^{a}$ Andrea Matos transmitida pelo canal E-for Cametá, disponível no link: "https://www.youtube.com/watch?v=_DbNamSGg0k\&t=7170s", realizada no dia 13 de maio, obtivemos 530 visualizações e abordou como tema "A ação dos novos reformadores e a implementação da Base Nacional Comum Curricular para a Educação Infantil".

Essa palestra foi muito importante para o professor refletir sobre sua prática educativa em relação a implementação da BNCC (2018), que é uma das políticas educacionais, que se tornou obrigatória, de modo a desenvolver o pensamento criativo e crítico, para com isso, trabalhar com as práticas sociais desde a educação infantil, contemplando assim, o eixo diversidade cultural.

Após a palestra, abriu- se o espaço para questionamento dos professores e diálogo com a formadora, sendo um momento de troca de conhecimento, e foi bastante produtivo para a qualidade da educação de nossas crianças, em que professores relataram excelentes reflexões sobre as antigas e novas políticas educacionais, os papeis dos empresários na educação básica.

E a palestra da prof. ${ }^{a}$ Ma Verena Cissa, ocorreu no mesmo dia da prof. ${ }^{a}$ Dr. $^{a}$ Andrea, transmitida também pelo canal E-for Cametá: "https://www.youtube.com/ watch?v=_DbNamSGgOk\&t=7170s, obteve 530 visualizações, tratou do tema: "Sequência didática: usando práticas socioculturais na Educação Infantil " e trouxe como professora convidada a Prof. ${ }^{a}$ Maria Lucilene de Souza Rodrigues, da Escola Municipal de Ensino Infantil e Fundamental Nossa Senhora do Carmo, do Distrito de Curuçambaba, Cametá/PA, que compartilhou uma sequência didática sobre o matapi, que elaborou durante a formação sobre: "O matapi e o ensino da matemática mista", disponível no canal E-for: "https://www.youtube.com/watch?v=4QyDhG1gQal\&list=UUP1FHzA_aAM3k0x-F6232HQ\&index=6".

Dessa maneira, ambas as professoras mostraram suas sequências didáticas sobre o matapi, que é usado geralmente na pesca do camarão (SILVA, 2019) 
e além disso, a prof. Verena, construiu uma outra abordando o açaí, pois o camarão e o açaí, são alimentos regional bastante consumido pelos alunos das ilhas, bem como pela população em geral do município de Cametá.

Nesse sentido, por essas sequências partirem de algo conhecido pelos professores em formação, tornou-se interessante para eles, fazendo com que fosse desenvolvida e aprendida de maneira prazerosa.

E para finalizar o evento, foi mostrado um vídeo das crianças estudando em suas casas, que refletiu o momento atual pandêmico que estamos vivendo. Portanto, houve os parabéns a prof. ${ }^{a}$ coordenadora da divisão de educação infantil da SEMED, pela inciativa em fazer a formação acontecer ser tão necessária para os que estão atuando no ensino com as crianças.

\section{CONCLUSÕES}

A formação sobre prática de ensino multidisciplinares na educação infantil foi realizada em dois dias consecutivos e proporcionou um alcance significativo aos professores e professoras para trabalhar com a BNCC na educação infantil, partindo de uma postura crítica e investigativa, algo pontuado nas falas dos palestrantes acerca do desenvolvimento da autonomia docente, criticidade, trabalho multidisciplinar, interdisciplinar, trabalho colaborativo e integrado, isto é, integração da cultural local com a cultura global, de modo que a escola utilize os saberes locais onde está inserida, para que as crianças aprendam a respeitar e valorizar a sua cultura, interagindo com os saberes escolares, que podem emergir das práticas socioculturais (SILVA, 2019).

Para além disso, a formação continuada reforçou a necessidade dos docentes nas construções de estruturas didáticas para trabalhar com as crianças, isto é, ter autonomia na construção das atividades e conteúdo, o que demanda questionar e problematizar o saber posto nos livros didáticos, sites como os da nova escola, uol, etc., (CHEVALLARD, 2009), para com isso, dá voz aos anseios e desejos de nossas crianças que estão na zona urbana e no campo. 


\section{REFERENCIAS}

BRASIL. Base Nacional Comum Curricular - BNCC. 2018. Disponível em: http://basenacionalcomum.mec.gov.br/. Acesso em: 10 nov. 2020.

BRASIL. Parâmetros Curriculares Nacionais do Ensino Médio. Brasília, 1999.

CHEVALLARD, Yves. La transposição didática. 3. ed. Buenos Aires: Aique grupo, 2009.

CHEVALLARD, Yves. A análise das práticas na teoria antropológica da didactico1 de ensino. Recherches em Didactique des mathématiques, v. 19, n. 2, p. 221266, 1999.

D'ARTIBALE, Eloana Ferreira; RODRIGUES, Bruna Caroline.; MARCON, Sonia Silva.; BERCINI, Luciana Olga.; HIGARASHI, leda. Harumi. Criança, família e equipe multidisciplinar: intersecções do cuidado - estudo. braz. J. nurs., v.10, n. 3, set-dez, 2011.

FARIAS, Guilherme. Engenharia reversa. Guiky. 2009. Disponível em: http:// www.guiky.com.br/2009/09/engenharia-reversa.html. Acesso em: 06 jul. 2021.

GODOY, Arilda Schmidt. Pesquisa qualitativa, tipos fundamentais. Revista de Administração de Empresas, São Paulo, v. 35, n.3, p, 20-29 Mai./Jun. 1995. Disponível em https://www.scielo.br/j/rae/a/ZX4cTGrqYfVhr7LvVyDBgdb/?forma$\mathrm{t}=$ pdf. Acesso em: 06 jul. 2021.

MORAES, Sergio Cardoso de. Saberes da pesca: uma arqueologia da ciência da tradição. 2005. Disponível em: http://ftp.ufrn.br/pub/biblioteca/ext/bdtd/SergioCM.pdf. Acesso em: 06 jul. 2021.

MORAIS, Nadja Maria de Menezes; RÊGO, Thiênia Bonifácio do; LIMA, Marcos José Andrade. Projeto ama: apoio multidisciplinar de aprendizagem uma prática inclusiva na educação infantil. In: CONGRESSO NACIONAL DE EDUCAÇÃO, 3, 2016. Natal. Anais [...]. Natal: realize, 2016. Disponível em: http://www.editorarealize.com.br/editora/anais/conedu/2016/TRABALHO_EV056_MD4_SA17_ ID3903_15082016191907.pdf. Acesso em: 06 jul. 2021.

PETRAGLIA, Izabel Cristina. Interdisciplinaridade: o cultivo do professor. São Paulo: Universidade São Francisco, 1993. 
PIRES, Marilia Freitas de Campos. Multidisciplinaridade, Interdisciplinaridade e Transdisciplinaridade no Ensino. Interface - Comunic, Saúde, Educ 2. fevereiro/1998. Disponível em: https://repositorio.unesp.br/bitstream/handle/11449/30363/S1414-32831998000100010. pdf? sequence=1\&isAllowed=y. Acesso em: 06 jul. 2021.

SILVA, Renata Lourinho da. Engenharia didática reversa como um dispositivo de formação docente para a Educação do campo. 2019. 300f. Tese (doutorado em educação matemática) - Instituto de Educação e Matemática e Cientifica, Universidade Federal do Pará, Belém, 2019.

SILVA, Renata Lourinho da. O percurso de estudos e investigação e a manifestação de habitus. 2020. In: CORRÊA, Marcos Britto; ROSA DOMINGUEZ, Fabiane da; BAUTISTA NUÑEZ, Marcela (Org.). Educação, pesquisa e produção do conhecimento: distintos enfoques e abordagens no cenário atual. Rio de Janeiro: Dictio Brasil, 2020. p. 214-229.

SOUZA, Salete Eduardo de. O uso de recursos didáticos no ensino escolar. In: I Encontro de Pesquisa em Educação, IV Jornada de Prática de Ensino, XIII Semana de Pedagogia da UEM: "Infância e Práticas Educativas". Arq Mudi. 2007.

SOUZA, Thalita Saramago de; HAHN, Claudia Emanuela Honorario; COSTA, Jaqueline Batista de Oliveira. Multidisciplinaridade no contexto escolar: relato de experiência no pibid/psicologia. Seminário de Avaliação do Programa Institucional de Bolsa de Iniciação à Docência UFGD/UEMS/PIBID, 2017. Disponível em: https://seminariopibidufgduems.webnode.com/anais-do-seminario/. Acesso em: 17 ago. 2021.

TONETTO, Aline Maria; GOMES, William Barbosa. A prática do psicólogo hospitalar em equipe multidisciplinar. Estud. psicol. Campinas. 2007, v. 24, n.1, pp. 89-98. Disponível em http://dx.doi.org/10.1590/S0103-166X2007000100010. Acesso em: 17 ago. 2021. 
doi $10.48209 / 978-65-89949-24-8$

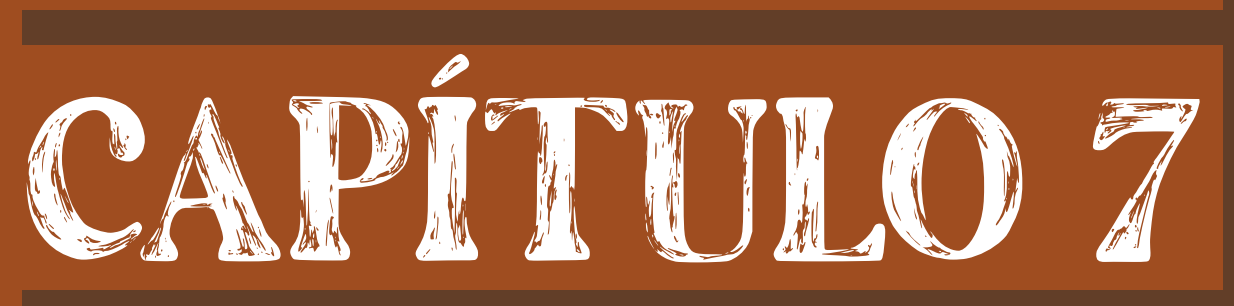

\section{ATFABEHEAÇÃO DE CRIANÇASS COM NECESSIDADES EDUCATHVAS ESPECIATS NA SAIA DE RECURSOS: CONHRIBUIÇÕES DO USO DE} PIAATAFORMAS EDUCACIONAIS

Claudinéia Garcia Ferreira de Oliveira Maria Helena da Costa Bianchi Maria Lucivane de Oliveira Morais 


\section{INTRODUÇÃO}

A temática abordada nesse artigo abrange o processo de alfabetização de crianças com necessidades educativas especiais, tendo em vista, especificamente, o trabalho desenvolvido pelo professor que atua na Sala Multifuncional de Recursos. Embora a literatura especializada trate amplamente do assunto, ainda faltam sugestões de práticas pedagógicas como as apresentadas a seguir e que podem facilmente ser adaptadas ou inseridas na rotina dos docentes e educandos inseridos nesse ambiente.

A Lei de Diretrizes e Bases da Educação (LDB, Lei n 9394/96) ao ser promulgada, assegurou a matrícula preferencial desses educandos no ensino regular, ao mesmo tempo em que garantiu o acesso a um Atendimento Educacional Especializado (AEE) para que tenham condições de aprender e se desenvolver em um ambiente rico em estímulos, onde suas dificuldades e potenciais são reconhecidos e valorizados, o currículo adaptado dentre outras mudanças específicas a cada caso.

Esse AEE dependerá do tipo de necessidade apresentada. A criança poderá contar, por exemplo, além do professor regente com outro docente que o acompanha no período regular de aulas para lhe auxiliar, como é o caso de autistas e deficientes auditivos. Aqueles que apresentam outras limitações como a dislexia, dislalia, dificuldades para serem alfabetizados, etc., poderão ser auxiliados por um professor de Educação Especial que realiza atendimento no período contra turno na Sala de Recursos.

Como na infância o brincar é algo natural a todas as crianças, também optou-se por discutir nesse estudo, as contribuições da utilização das plataformas educacionais que disponibilizam jogos já prontos (Racha cuca) e/ou que podem ser elaborados pelos professores de acordo com os conteúdos ministrados (WordWall) e os apps (Zookazan e Quiver - 3D coloring app) que podem ser baixados em celulares e tablets para trabalhar com a realidade aumentada. 
Os subitens seguintes discutem aspectos gerais da educação inclusiva no Brasil e as especificidades do trabalho desenvolvido na sala de recursos pelo professor alfabetizador. As plataformas educacionais anteriormente mencionadas, são instrumentos de grande valia nesse processo tornando as aulas mais lúdicas, dinâmicas e motivadoras. Sua descrição serve como sugestão para outros docentes que procuram informações almejando melhorar suas intervenções.

A metodologia utilizada baseou-se inicialmente em pesquisa bibliográfica, qualitativa e descritiva, que permitiu embasar teoricamente as reflexões que ancoraram o relato de experiência apresentado na parte final deste artigo.

\section{ASPECTOS GERAIS DA EDUCAÇÃO INCLUSIVA NO BRASIL}

O público alvo da educação inclusiva abrange pessoas em idade de escolarização ou que não tenham concluído a educação básica na idade indicada pela LDB, regularmente matriculados em escolas comuns que apresentam deficiência física, auditiva, visual e intelectual), Transtornos Globais do Desenvolvimento (TGD), altas habilidades/superdotação e/ou outras necessidades educativas especiais temporárias ou permanentes.

O ensino superior também conta com legislação específica para que esses indivíduos tenham condições de acesso e permanência, conseguindo concluir um curso de graduação, seja ele, tecnólogo, bacharelado ou licenciatura e/ou pós graduação (MARCOTTI, MARQUES, 2017).

A declaração Universal dos Direitos humanos que foi publicada em 1948, reconhece no seu $1^{\circ}$ artigo que "[...] Todos os seres humanos nascem livres e iguais em dignidade e em direitos. Dotados de razão e de consciência, devem agir uns para com os outros em espírito de fraternidade". Tal afirmação inspirou a ampliação das discussões em tono da Educação Especial, em todo o mundo, culminando na produção de inúmeros estudos, legislações e mudanças sociais significativas, sobretudo, na forma como as pessoas com deficiência eram compreendidas. 
De acordo com Brasil (2008, p. 01):

A educação inclusiva constitui um paradigma educacional fundamentado na concepção de direitos humanos, que conjuga igualdade e diferença como valores indissociáveis, e que avança em relação à ideia de equidade formal ao contextualizar as circunstâncias históricas da produção da exclusão dentro e fora da escola.

Para que o reconhecimento, a valorização dessas diferenças, garantia de direitos e acesso à educação formal fosse estendida aos cidadãos com necessidades especiais, foi necessário um longo percurso histórico marcado por lutas, reinvindicações, organização de movimentos sociais, das famílias, estudos na área da Psicologia e médica que comprovaram seu potencial de aprendizagem, dentre outras situações.

No Brasil, as pessoas com deficiência foram tradas de múltiplas formas, havendo períodos em que eram totalmente excluídas da sociedade, escondidas e mal vistas; entendidas como castigo divino a pais pecadores; como seres dignos de pena, cuja vida deveria ser mantida por piedade e caridade dos cristãos; momentos em que foram segregadas em escolas de educação especial, até o período em que integração passou a ocorrer na década de 1960, abrindo caminho para que a inclusão rompesse paradigmas e se efetivasse na década de 1990, ancorada em inúmeros debates, reinvindicações e perspectivas de mudanças na organização da educação básica, especialmente, em escolas públicas.

De forma clara, a construção das políticas públicas em torno da educação de pessoas com necessidades educativas especiais, começaram a ganhar força a partir da década de 1960, tendo em vista a integração dos alunos especiais nas escolas regulares, embora esse modelo ainda não fosse suficiente para assegurar sua aprendizagem e desenvolvimento escolar, tampouco, a eliminação dos preconceitos nutridos pelos outros educandos sem limitações que frequentavam o mesmo espaço.

Ao descrever esse modelo educacional, Mantoan (2003, p. 23) pontua: 
alunos que estão aptos à inserção. Para esses casos, são indicados: a individualização dos programas escolares, currículos adaptados, avaliações especiais, redução dos objetivos educacionais para compensar as dificuldades de aprender. Em suma a escola não muda como um todo, mas os alunos têm de mudar para se adaptarem às suas exigências.

Como pode ser evidenciado no fragmento textual, embora os objetivos do modelo de integração fossem inicialmente positivos, os alunos continuavam excluídos frequentando as classes especiais nas escolas públicas, eram classificados e a partir disso, tinham acesso ao processo de ensino de aprendizagem que não atendia plenamente suas necessidades.

Por outro lado, aqueles educandos com maiores comprometimentos, que não conseguiam seguir o ritmo pré-determinado na escola regular, permaneciam matriculados em instituições filantrópicas, ou seja, também continuavam segregados da sociedade.

No ano de 1994, passou a vigorar a Política Nacional de Educação Especial que tinha objetivo orientar o desenvolvimento do processo de "integração instrucional" por meio da matricula em classes comuns do ensino regular dos educandos que "[...] possuem condições de acompanhar e desenvolver as atividades curriculares programadas do ensino comum, no mesmo ritmo que os alunos ditos normais" (BRASIL, 1994, p.19). Gradativamente a educação especial passou por novas ressignificações culminando na inclusão.

Após a publicação da Lei de Diretrizes e Bases da Educação (Lei $n^{\circ}$ 9394/96), inúmeros outros decretos e documentos orientadores, fizeram com que o modelo de integração que perdurou por quase três décadas fosse substituído pela inclusão. Esta, trouxe em seu bojo novos objetivos, formas de compreender os educandos com necessidades especiais, os papéis exercidos pelos docentes, a organização da escola e do currículo, bem como, inúmeras outras mudanças. (FIGUEIRA, 2017).

Para Conte e Habowski (2021, p. 1390) dentre as inúmeras contribuições da inclusão, está o combate ao preconceito e o fato de que "[...] reconhece as diferenças como acontecimentos próprios da vida, buscando a valorização das 
diferenças na ênfase e estímulo às habilidades, capacidades e potencialidades de cada pessoa".

Nesse modelo educacional, os alunos especiais e sem quaisquer limitações frequentem o mesmo espaço da sala de aula ${ }^{13}$, no ensino regular, tendo seus potenciais de aprendizagem reconhecidos e valorizados, contando com o apoio pedagógico e todas as adaptações necessárias para seu desenvolvimento. Como consequência disso, consolidaram-se mudanças significativas na organização educação brasileira, na própria sociedade, no modo como esses educandos eram e ainda são vistos.

O artigo 60 da LDB deixa bem claro a obrigatoriedade de o Estado adequar as instituições públicas de ensino da rede para receberem adequadamente os alunos com necessidades educativas especiais. Vale mencionar as legislações que tratam dessa temática também asseguram que instituições privadas e/ou filantrópicas que atuam com a educação especial possam contar com apoio técnico e financeiro para realizar o atendimento. (BRASIL, 1996).

Desde então, o processo de inclusão se tornou cada vez mais presente nas salas de aula, instigando os docentes a se qualificarem para compreender de forma mais específica, as características das necessidades educativas especiais de seus alunos, as metodologias que podem utilizar, bem como, as exigências que Ihe são lançadas para a promoção efetiva de sua aprendizagem e dos demais colegas que frequentam a mesma sala de aula. (CAMARGO, 2017).

Nesse contexto, Brasil (2008, p. 10) afirma que o trabalho docente:

[...] postula uma reestruturação do sistema educacional, ou seja, uma mudança estrutural no ensino regular, cujo objetivo é fazer com que a escola se torne inclusiva, um espaço democrático e competente para trabaIhar com todos os educandos, sem distinção de raça, classe, gênero ou características pessoais, baseando-se no princípio de que a diversidade deve não só ser aceita como desejada.

As escolas inclusivas servem de inspiração e referência para as demais, permitindo que todas as crianças aprendam efetivamente, pensando em seus rit-

13 Contexto totalmente diverso da integração. 
mos, potenciais e dificuldades. As abordagens realizadas pelos docentes têm em vista a formação humana integral desses cidadãos, difusão de valores voltados a compreensão de que todos são diferentes e capazes de se desenvolver.

Todas as ações desenvolvidas nas escolas inclusivas permitirão a criação de uma rede de suporte, para que os educandos com diferentes necessidades especiais, sejam elas temporárias ou permanentes, possam ser atendidos com qualidade, tendo acesso a uma educação crítica e transformadora.

Para isso, a sala de aula passa a ser permeada por um ensino flexível, cujas metodologias, recursos materiais e didáticos se alternam, beneficiando a todos, de modo que as crianças e adolescentes possam aprender juntos, descobrindo a si, ao outro e, sobretudo, os seus potenciais. (MARCOTTI, MARQUES, 2017).

Vale mencionar que a realidade anteriormente narrada e apoiada em inúmeros instrumentos legais que orientam a educação, não se efetiva de forma igualitária em todas as instituições de ensino do país, uma vez que, inúmeros professores ainda não contam com a formação adequada para atender esse público, tampouco tem recursos próprios para investir em cursos de especialização; muitas instituições não possuem infraestrutura, recursos materiais e humanos; faltam investimentos, dentre inúmeros outros problemas que ainda precisam ser superados. (CONTE; HABOWSKI, 2021).

Apesar de tantas limitações, defendemos que os alunos inclusos precisam contar com professores fantásticos, dispostos a enfrentar as adversidades, estudarem, buscaram informações que Ihes permitam conhecer as especificidades do seu caso e, a partir disso, contribuir para sua formação, ampliando seus potenciais e reduzindo as dificuldades.

O aluno especial, assim como, qualquer outro, é capaz de aprender, entretanto, tem seu ritmo próprio e pode precisar de estímulos específicos que se diferem dos demais. Trabalhar com a educação inclusiva exige mais do que o diploma em um curso de licenciatura e/ou especializações em educação especial, 
implica também em amor, dedicação, comprometimento, empatia e, sobretudo, a consciência de que lidamos com seres humanos, dotados de potenciais e possibilidades que precisam ser descobertas.

Para isso, além das mediações realizadas no período regular de aulas, os alunos especiais, caso necessitem, poderão contar com o apoio dos professores que atuam na Sala Multifuncional de Recursos, ou simplesmente, Sala de Recursos, que é objeto de interesse no próximo subitem.

\section{SAla MUltifuncional DE RECURSOS E O USO DAS PLATAFORMAS EDUCACIONAIS}

De acordo com a Resolução CNE/CEB n 4/2009, a educação inclusiva abrange todas as etapas, níveis e modalidades da educação brasileira e, para que as crianças e adolescentes especiais possam ser efetivamente inclusos, caso precisem, poderão receber Atendimento Educacional Especializado (AEE) tanto no ensino regular quanto na sala multifuncional de recursos (SMR).

A sala de recursos é um ambiente que funciona no contra turno escolar, com um professor habilitado em Educação Especial ${ }^{14}$ que trabalha de maneira individualizada ou em pequenos grupos. Nela, estão disponíveis materiais didáticos e pedagógicos, bem como, mobiliários distintos que contribuirão para fortalecer o processo de ensino e aprendizagem desses educandos, complementando qualitativamente seu processo de formação. (CAMARGO, 2017).

Ao pensar nas especificidades desse ambiente, Alves (2006, p.14) enfatiza que:

14 É importante mencionar que além do atendimento direto dos educandos especiais de forma individualizada e/ou em pequenos grupos, o professor da SMR exerce um papel de grande relevância no contexto educacional, orientando pais sobre as mais diversas temáticas, como a busca por outros profissionais especializados, o modo como deve estimular seus filhos, apoiando-os e potencializando seu desenvolvimento de forma conjunta com a escola, fases de desenvolvimento, sexualidade, relacionamentos com os colegas, professores, dificuldades e avanços conquistados, etc. Esse profissional também norteará os professores que ensinam diversas disciplinas no ensino regular e, que geralmente mostram-se aflitos, com dúvidas sobre as estratégias metodológicas, aprendizagem dos educandos inclusos, adaptações curriculares e de materiais, dentre outras dificuldades envoltas na rotina da sala de aula. 
[...] esse espaço pode ser utilizado para o atendimento das diversas necessidades educacionais especiais e para desenvolvimento das diferentes complementações ou suplementações curriculares. Uma mesma sala de recursos pode atender alunos com deficiência, autismo, hiperatividade ou outras necessidades educacionais especiais. Portanto, essa sala de recursos é multifuncional em virtude de a sua constituição ser flexível para promover os diversos tipos de acessibilidade ao currículo, de acordo com as necessidades de cada contexto educacional.

Na SMR o docente irá analisar as especificidades de cada educando, seu histórico educacional e, a partir disso, elaborará um plano de intervenção destacando a quantidade de atendimentos a serem realizados por semana, se o trabalho será individualizado ou com outras crianças com as mesmas deficiências, transtornos globais do desenvolvimento (TGD), altas habilidades/superdotação, distúrbios de aprendizagem, dentre outras especificidades, visando seu desenvolvimento pleno.

Os conteúdos abordados na SRM não substituem aqueles que estão no currículo e são indicados para cada série e idade, pelo contrário, eles possuem caráter suplementar para aqueles com altas habilidades/superdotação ou complementar para aqueles com deficiências ou outras necessidades especiais educacionais (FIGUEIRA, 2017).

As adaptações e os serviços prestados pelo professor que oferece o AEE, deverão atender "[...] as características dos estudantes com deficiência e garantir o seu pleno acesso ao currículo em condições de igualdade, para conquistar o pleno exercício de sua cidadania" (SANTOS, et al., 2017, p. 17).

O Atendimento Educacional Especializado (AEE) poderá ser realizado a partir da utilização de diversos recursos, entretanto, optou-se por discutir nesse artigo sobre as contribuições das plataformas educacionais para a alfabetização e desenvolvimento das habilidades leitoras dos educandos especiais, ampliando sua capacidade de análise, senso crítico, pensamento abstrato e estratégico, dentre outros benefícios citados no próximo subitem. 


\section{INFÂNCIA, ALFABETIZAÇÃO E O PROCESSO DE ENSINO E APRENDIZAGEM POR MEIO DO LÚDICO}

Durante a infância a criança forma sua personalidade, portanto, o modo como é direcionada no ambiente escolar, as mediações, os vínculos afetivos estabelecidos com o seu professor, a qualidade das interações sociais com seus colegas, e, sobretudo, a representatividade que a escola passa a ter em seu íntimo, serão determinantes para que possa vivenciar seu desenvolvimento humano integral.

$\mathrm{Na}$ educação infantil e nos anos iniciais do ensino fundamental, o brincar, os jogos e as brincadeiras fazem parte do processo de ensino e aprendizagem, que necessita ser constantemente refletido e autoavaliado. Os jogos são planejados previamente pelos professores, seu direcionamento é feito de maneira intencional, com o objetivo de potencializar sua aprendizagem, ampliar suas habilidades motoras, intelectuais e sociais. (NASCIMENTO MOURA, 2019).

$\mathrm{Na}$ infância as atividades lúdicas devem proporcionar a vivência de uma aprendizagem prazerosa e significativa. Os talentos e habilidades infantis serão aprimorados de acordo com a faixa etária, as atividades propostas, a conquista de novas habilidades motoras, cognitivas e sociais de maneira gradativa ao longo do ano letivo.

Para Rinaldi (2017, p.77):

O ambiente escolar deve ser um lugar que acolha o indivíduo e o grupo, que propicie a ação e a reflexão. Uma escola ou uma creche é antes de mais nada, um sistema de relações em que as crianças e os adultos não são apenas formalmente apresentados a organizações, que são uma forma da nossa cultura, mas também a possibilidade de criar uma cultura. [...] É essencial criar uma escola ou creche em que todos os integrantes se sintam acolhidos, um lugar que abra espaço às relações.

Para isso, o professor necessita ser bem qualificado e contar com um currículo que the permita utilizar múltiplos métodos lúdicos capazes de despertar na criança o prazer pela aprendizagem, confiança em si, independência e tantas outras qualidades e competências. 
Enfatiza-se que, dentre as vantagens das brincadeiras, dos jogos e do brincar na infância, figuram a ampliação de sua coordenação motora, capacidade cognitiva, de cooperação, socialização, mas também da autoestima e do prazer em estar em um ambiente onde cada criança é valorizada, no qual o professor reforça constantemente seus avanços e conquistas.

Por meio do lúdico os professores também se deparam com a oportunidade de realizar o processo de alfabetização. Aprender a ler e escrever exige da criança muita atenção, dedicação e motivação, uma vez que, a descoberta do código escrito ocorre de forma individualizada e com diferentes ritmos.

Para Scholze e Rosing (2007, p.09), "saber ler e escrever é, para o indivíduo, uma garantia de existência política e cultural num país que, por sua vez, se pretenda ser letrado e, assim, desenvolvido". Portanto, o contato com um texto escrito, deve ser compreendido como um ato repleto de vida, por isso, deveria estar presente no cotidiano de todas as pessoas, em sua prática diária de comunicação, nos conhecimentos partilhados por toda a sociedade.

Para facilitar o processo de alfabetização de crianças com necessidades educativas especiais, assim como dos seus colegas matriculados nos anos iniciais do ensino fundamental, é possível utilizar qualitativamente o potencial lúdico trazido pelos jogos disponibilizados em plataformas educacionais online. Ancoradas em tal afirmação, foram tecidas as reflexões seguintes sobre essa temática.

\section{RESULTADOS E DISCUSSÃO: RELATO DE EXPERIÊNCIA}

O desenvolvimento das novas Tecnologias de Informação e Comunicação (TICs) proporcionou inúmeras transformações na forma como o processo de ensino e aprendizagem é ministrado no ambiente escolar. Com a pandemia que teve início no ano de 2020 e a suspensão das aulas como estratégia para conter o avanço do COVID-19 que, inicialmente, não contava com uma vacina, as formas como as relações entre os professores e alunos se desenrolavam modificaramse profundamente. 
Inicialmente, as aulas remotas permitiam o contato entre o aluno e o professor, o acesso aos conteúdos previstos no currículo, o debate e as interações. De forma bastante clara, ambos precisaram se adaptar a esse novo contexto e utilizar as TICs cotidianamente.

Em meio a esse cenário, as plataformas educacionais, ou seja, os sites criados para facilitar o processo de ensino e aprendizagem por meio de jogos, por exemplo, ampliaram sua importância, facilitando o desenvolvimento continuo e qualitativo dos educandos possuidores ou não de necessidades especiais, bem como, a manutenção de sua motivação para manter a rotina de estudos mesmo em suas casas.

Em Foz do Iguaçu, cudade localizada no Paraná, com o retorno das aulas presenciais nas Escolas Municipais, o trabalho desenvolvido nas salas de recursos se fortaleceu. $\mathrm{Na}$ instituição analisada nesse relato de experiência, a docente, habilitada em Educação Especial e, com 15 anos de experiência, atende no período matutino 10 alunos que possuem laudo que apontam para deficiência intelectual, dislexia e dificuldades de aprendizagem diversas.

Contudo, ainda existem outros 6 educandos atendidos que estão sendo acompanhados e aguardam a finalização do seu diagnóstico para o delineamento do plano de intervenção a ser efetivado em seu Atendimento Educacional Especializado (AEE). Momentaneamente, eles frequentam a sala de recursos porque estão matriculados no terceiro ano e não são alfabetizados, por isso, tem grande dificuldade de acompanhar os colegas e realizar as atividades propostas pelo professor do ensino regular.

Dentre as diversas estratégias de ensino e aprendizagem, a docente utiliza sites específicos como WordWall que the permite pode elaborar jogos e/ou utilizar atividades já criadas por outros professores, acompanhar os resultados de seus alunos, evolução, erros e acertos. Nele, o educando pode refazer a atividades inúmeras vezes, até que obtenha o resultado que almeja e, consequentemente, se aproprie dos conceitos. 
A figura abaixo foi extraída de um jogo disponibilizado no WordWall com o objetivo de fortalecer a habilidade de leitura e compreensão de conceitos pelos educandos que estão sendo alfabetizados. A temática escolhida pelo professor abrangeu elementos constitutivos de uma festa junina como pode ser observado a seguir:

Figura 1 - Jogo: A festa junina

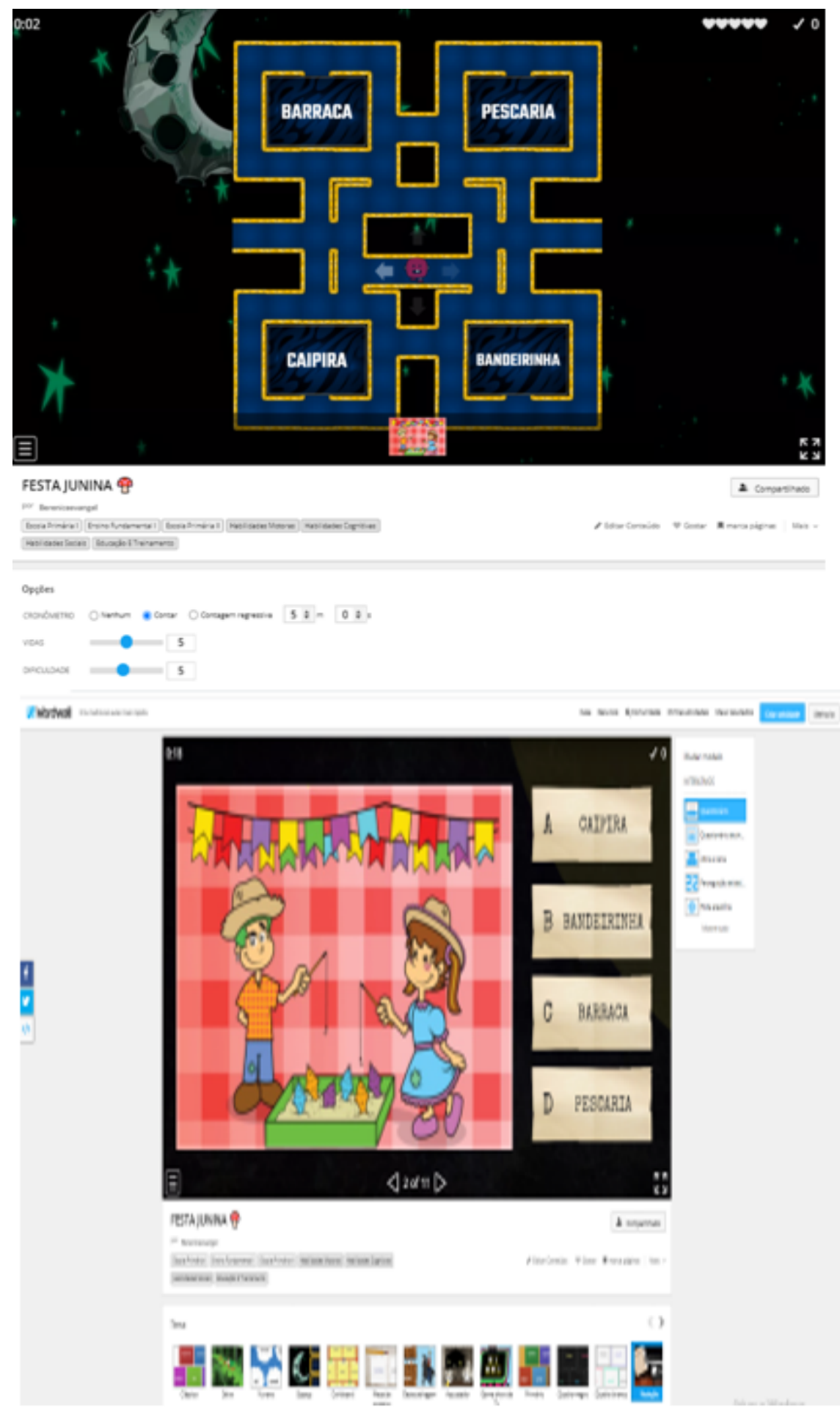

Fonte: https://www.wordwall.net/resource/16883725/motor-skills/festa-junina- 
No canto direito da tela do Wordwall o professor tem a possibilidade de escolher o modelo interativo que deseja, como exemplo, foram inseridos os dois anteriores. O primeiro em forma de quizz, onde o aluno faz a leitura dos itens e clica sobre ele; no segundo, ele utiliza as setas do computador para fugir dos inimigos e chegar com o seu boneco até a casinha onde está a resposta correta.

Para acessar, o professor envia o link para os alunos. Eles precisam inserir seu nome para iniciar as atividades em forma de jogos. Quando concluem, o professor tem acesso a um relatório onde pode acompanhar a quantidade de alunos e não alunos que fizeram a atividade caso ela fique aberta no site; as questões com um índice maior de erros e acertos, os três alunos que tiveram melhores resultados e o tempo dedicado a atividade.

Também existem aplicativos que podem ser baixados no celular como, por exemplo, o Zookazan e Quiver - 3D coloring app, ambos permitem utilizar a realidade aumentada. O primeiro app tem inúmeros animais e o segundo vários temas que facilitam a alfabetização, desenvolvimento da habilidade matemática, etc.

O Quiver pode ser baixado pelo play store em celulares android, os desenhos impressos e coloridos pelas crianças e, em seguida, visualizados como realidade aumentada quando a câmera do celular é apontada para ele. 
Figura 2 - Realidade Aumentada - App Quiver

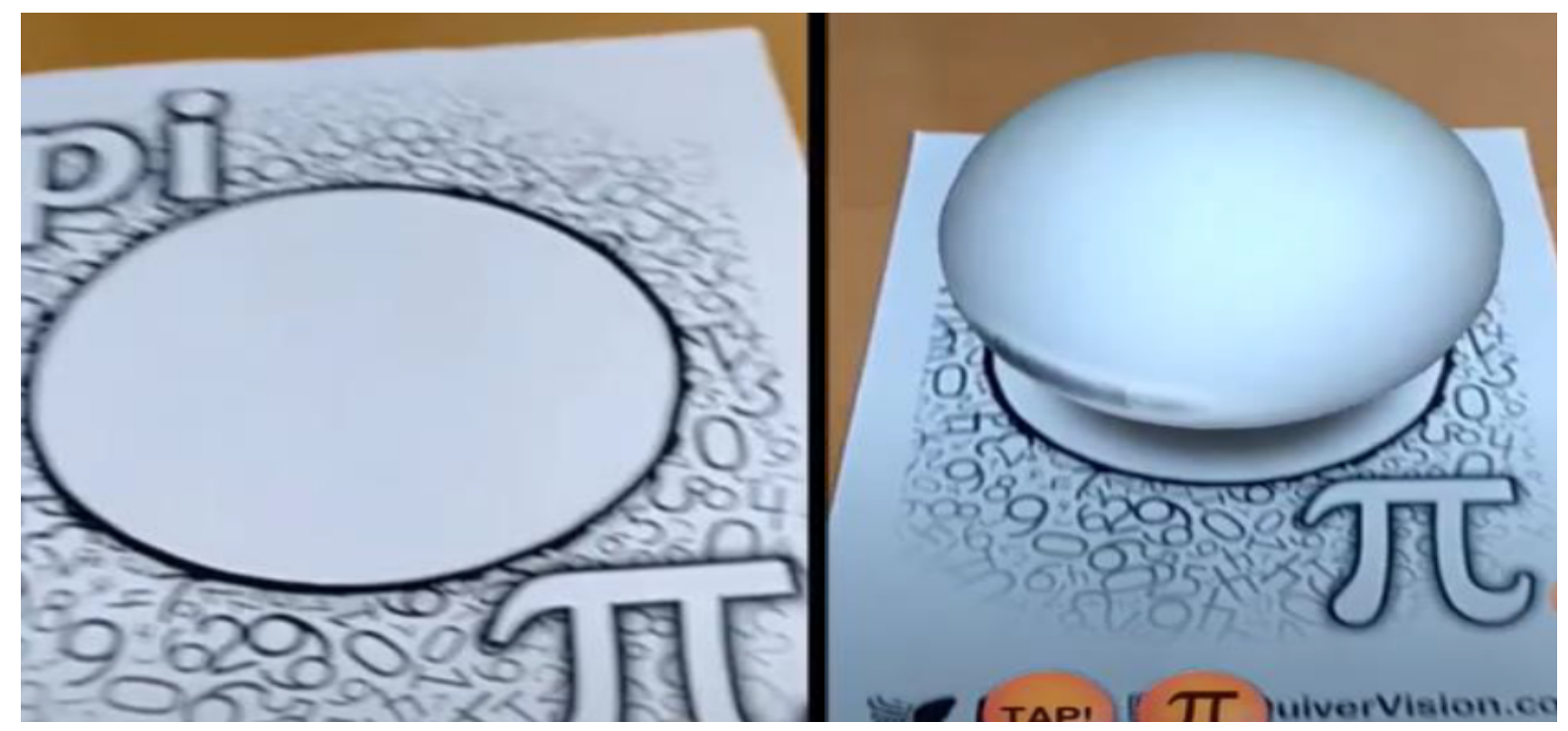

Fonte: Quiver.

No exemplo anterior, é possível visualizar um elemento da Matemática, o número $\mathbf{m}(\mathbf{P I})$ que representa o valor da razão entre a circunferência de qualquer círculo e seu diâmetro. No item pacotes, o professor pode escolher os desenhos que utilizará em sua aula e embora alguns sejam pagos, existem inúmeros outros gratuitos que podem ser utilizados no processo de ensino e aprendizagem em múltiplas situações.

Outro site que as mediações alfabetizadoras, bem como, o fortalecimento da aprendizagem de alunos em séries mais avançadas que possuem as mais diversas dificuldades e transtornos de aprendizagem, é o Racha Cuca. Ele traz inúmeros tipos de jogos (batalha naval, cartas, sinuca, damas, canhão numérico, etc), quizz, palavras cruzadas, passa tempos, palavras quebradas, blocos, dentre outros, que permitem ao professor escolher atividades de acordo os potenciais que precisam ser explorados e as dificuldades apresentadas pelos educandos atendidos 
Figura 3 - Racha cuca

\section{RachaCuca}

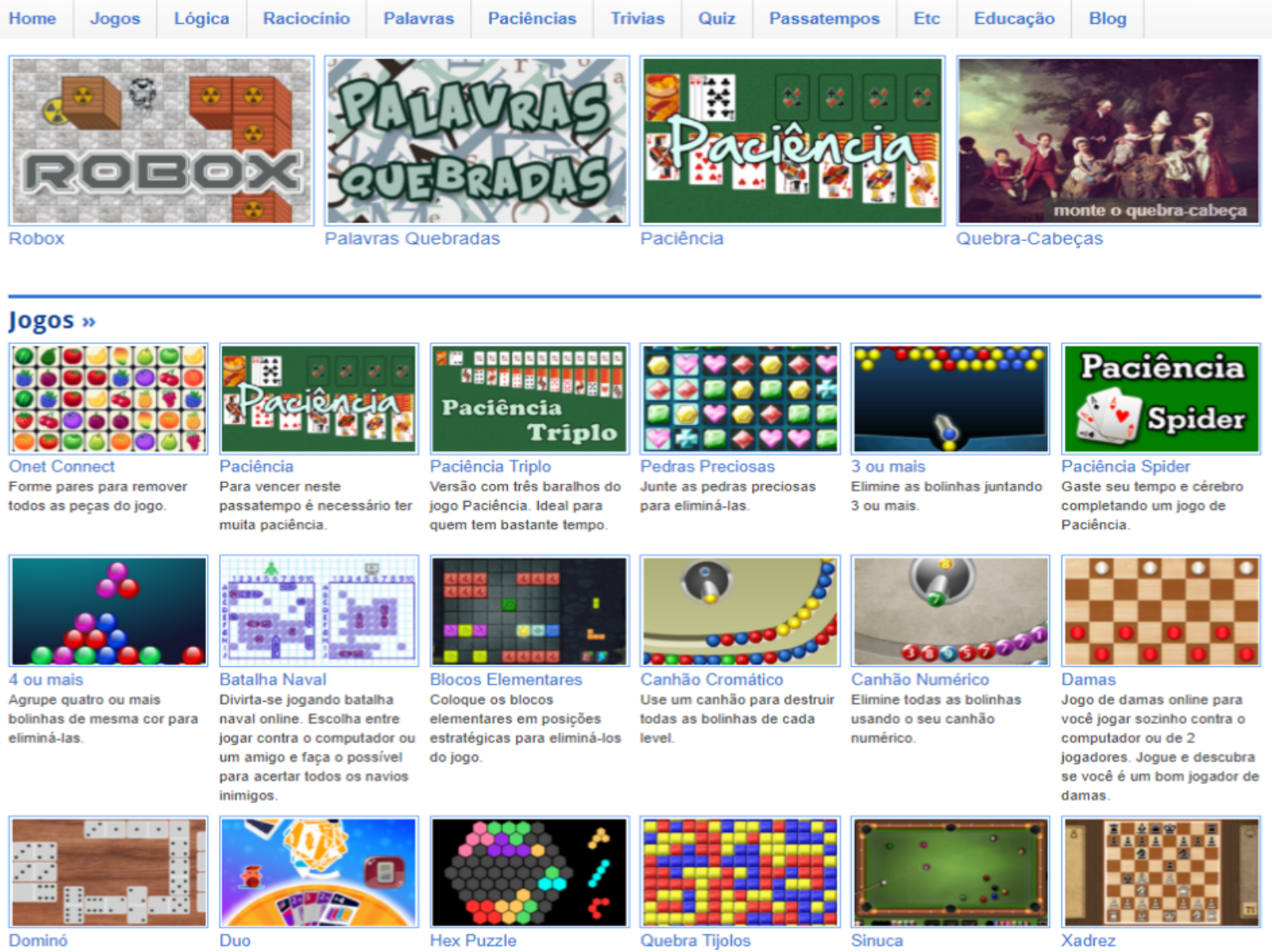

Fonte: https://rachacuca.com.br/

O layout do site, de imediato permite ao professor visualizar uma infinidade de jogos que trazem em si inúmeros fins pedagógicos. A escolha de cada um deverá estar alinhada as especificidades do seu aluno, que precisa conseguir resolvê-lo, sentindo-se desafiado e, ao mesmo tempo, capaz de superar os desafios que o jogo impõe. Esse educando especial, precisa perceber-se como capaz de aprender, evoluir e sentir-se realizado com os resultados obtidos.

Vale mencionar que a própria Secretaria Municipal de Educação de Foz do Iguaçu/PR, disponibiliza para os professores e alunos o acesso a várias atividades interativas, armazenadas em seu site, em virtude do reconhecimento de seus inúmeros benefícios para o seu desenvolvimento integral. 
Quando os alunos com necessidades educativas especiais, matriculados no terceiro ano e, que ainda, não sabem ler e escrever, apresentando inúmeras dificuldades, são postos diante dos computadores e orientados pela professora entrevistada para entrar nas plataformas educacionais específicas para aquela aula na Sala de Recursos, é perceptível em seus rostos a motivação e o interesse.

Um dos alunos atendidos com dificuldade de aprendizagem, foi alfabetizado com o apoio dessas plataformas educacionais. Atualmente, já consegue formar frases, entretanto, se recusa corriqueiramente a escrever no caderno e a fazer as atividades que o professor do ensino regular passa. Em virtude disso, no atendimento realizado na Sala de Recursos é preciso negociar como ele: pode fazer as atividades no computador, somente depois que concluir aquelas que foram passadas pelo professor do ensino regular.

Gradativamente, os professores dedicados a SMR precisarão criar, buscar ou adaptar metodologias para auxiliar esses educandos sendo elas online ou não, assim como, os docentes do ensino regular, deverão modificar sua forma de compreender o processo de ensino e aprendizagem, prática tradicionais de abordagem dos conteúdos, a avaliação, currículo, competências esperadas, e etc.

As discussões, apontamentos e sugestões realizadas nesse artigo permitem lançar luz sobre o fato de que a educação inclusiva ainda é um desafio que se lança cotidianamente sobre todos os docentes da educação pública e privada do país, equipe pedagógica, gestores e comunidade escolar, exigindo diferentes posturas e ações. Ainda há muito a ser feito, entretanto, inúmeros avanços também já foram conquistados.

\section{CONCLUSÃO}

A educação inclusiva é uma realidade presente nas mais diversas escolas públicas brasileiras que oferecem educação infantil, ensino fundamental e médio, perpassando por todos os seus níveis e modalidades. Como os alunos apresentam diferentes tipos de necessidades educativas especiais, deficiências, 
transtornos de desenvolvimento, dificuldades de aprendizagem temporárias ou permanentes, dentre outras limitações, os professores precisam contar com uma formação adequada para atendê-los no ensino regular e/ou na sala de recursos.

Optamos por discutir nesse artigo especificamente, sobre a sala de recursos e algumas possibilidades de intervenção realizadas pela docente entrevistada para alfabetizar seus educandos em uma escola pública municipal de Foz do Iguaçu, atendendo crianças com deficiência intelectual, dislexia e inúmeras outras dificuldades de aprendizagem laudados e, outros que ainda estão esperando o fechamento do seu diagnóstico.

Verificou-se o uso de plataformas educacionais, disponíveis em sites como o Wordwall e o Racha cuca, e os apps Zookazan e Quiver - 3D coloring app, que permitem tornar as aulas mais dinâmicas por meio da realidade aumentada. Em conjunto estas e outras plataformas educacionais, facilitam a aprendizagem, alfabetização e desenvolvimento de inúmeras outras competências infantis.

Na infância o brincar é algo natural, inerente a todas as crianças, por isso, aquelas que possuem necessidades educativas especiais, podem encontrar nessas plataformas educacionais a motivação necessária para aprender de uma forma mais prazerosa e motivadora, do que as rotinas da sala de aula no período regular. O professor da sala de recursos irá enriquecer suas aprendizagens e complementar os saberes já mediados, permitindo que as crianças possam se desenvolver qualitativamente.

As sugestões elencadas nesse artigo, sevem de inspiração para professores que buscam alternativas para tornar suas aulas mais dinâmicas, desenvolvendo as competências e habilidades dos seus alunos, especiais ou não, sem que para isso, precisem abandonar o currículo. É possível aprender brincando e os jogos disponibilizados nas plataformas cumprem um papel de grande relevância nesse processo.

Esse artigo não pretende esgotar as discussões acerca das temáticas propostas, pelo contrário, almeja dar sugestões sobre práticas de ensino 
voltadas a alfabetização ancoradas no uso de plataformas educacionais, mas, principalmente, gerar inquietações e auxiliar os docentes e/ou acadêmicos que irão fazer a sua leitura a se questionarem sobre o papel irão cumprir frente a inclusão, a forma como percebem cada aluno incluso, sua relação com os pais, colegas de turma, docentes e toda a comunidade escolar.

\section{REFERÊNCIAS}

BRASIL. Ministério da Educação. Secretaria de Educação Especial. Política Nacional de Educação Especial. Brasília: MEC/SEESP, 1994.

BRASIL. Política nacional de educação especial na perspectiva da educação inclusiva. Brasília, 2008. Disponível em: http://portal.mec.gov.br/arquivos/ pdf/politicaeducespecial.pdf. Acesso: 10 de abr. 2021.

BRASIL. Lei de Diretrizes e Bases da Educação (Lei n 9394/96). Disponível em: http://www.planalto.gov.br/ccivil_03/leis//9394.htm. Acesso: 10 de abr. 2021

CAMARGO, Eder Pires de. Inclusão social, educação inclusiva e educação especial: enlaces e desenlaces. Ciência \& Educação (Bauru), v. 23, n. 1, p. 1-6, 2017.

CONTE, Elaine; HABOWSKI, Adilson Cristiano. Educação inclusiva: diferentes configurações, olhares e mundos possíveis. Rev. Diálogo Educ., Curitiba, v. 21, n. 70, p. 1388-1412, jul./set. 2021. DOI: 10.7213/1981-416X.21.070.AO06

FIGUEIRA, Emílio. O que é educação inclusiva. São Paulo: Brasiliense, 2017.

MARCOTTI, Paulo; MARQUES, Michele Ferreira. Educação inclusiva-formação e prática docente. Revista de Pós-graduação Multidisciplinar, v. 1, n. 1, p. 7786, 2017.

MANTOAN, Maria Teresa Eglér. Inclusão escolar: pontos e contrapontos. São Paulo: Summus, 2003.

NASCIMENTO MOURA, Lenir Santos et al. A contribuição do lúdico para melhoria do processo de ensino e aprendizagem dos alunos do Ensino Fundamental. Revista Internacional de apoyo a la inclusión, logopedia, sociedad y multiculturalidad, v. 5, n. 3, p. 1-15, 2019. 
RINALDI, R. O. Alfabetização na Educação Infantil. Revista Nova Escola. n. 240, p.76 - 80, mar./2017.

SANTOS, João Otacílio Libardoni dos, et al. Atendimento educacional especializado: reflexões sobre a demanda de alunos matriculados e a oferta de salas de recursos multifuncionais na rede municipal de Manaus-AM. Revista Brasileira de Educação Especial, v. 23, p. 409-422, 2017.

SCHOLZE, Lia; ROSING, Tania Maria K. R. Teorias e práticas de letramento. Brasília, INEP, 2007.

VIEIRA, Fernanda Vivacqua. Direito fundamental à educação inclusiva. Revista Interdisciplinar Pensamento Científico, Rio de Janeiro, v. 5, n. 4, p. 140-157, 2019. 
dol $10.48209 / 978-65-89949-24-9$

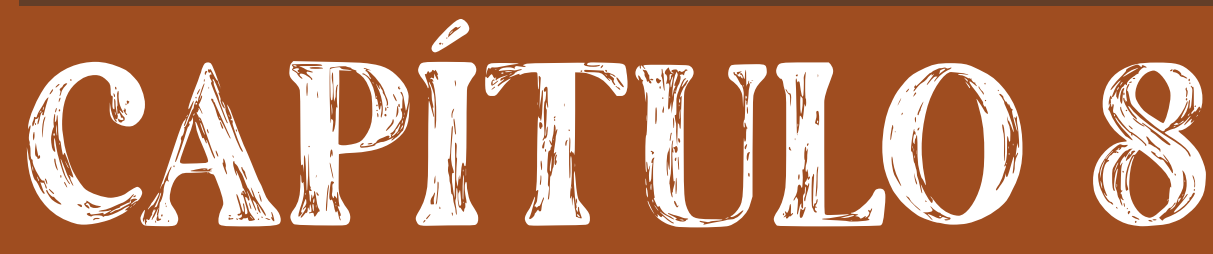

CRIANÇAS E TECNOLOGIAS: REFLEKÓES A PARTHR DE CONTHAENCIAS EM TEMMPOS DIGTHAIS

Adilson Cristiano Habowski Vinícius Barbosa Cannavô Tainá Suppi Pinto 


\section{CONSIDERAÇÕES INICIAIS}

Este estudo, de cunho ensaístico, exploratório e qualitativo, versa sobre as crianças desde a perspectiva de diversos autores que discutem e problematizam dois temas: as culturas infantis e as tecnologias digitais. Buscaremos fazer enlaces entre as duas temáticas a partir de pensadores que partem do campo do Estudos Culturais inspirados também na perspectiva pós-estruturalista. Ambas as perspectivas citadas se configuram como modos de olhar para os sujeitos, espaços e artefatos produzidos no seio da cultura. Dessa forma, moldam o modo como fazemos pesquisa, delineando aquilo que olhamos e como olhamos e aquilo que falamos e como falamos (FOUCAULT, 1993). Dessa forma, se faz,

então, frequentemente, uma distinção entre "visão" (aquilo que o olho humano é fisiologicamente capaz de ver; e que também muda ao longo do tempo) e "visualidade" ou "regime escópico", que implica considerar e entender que a visão é produzida de diferentes modos que definem e delineiam como vemos o que estamos aptos a ver e como vemos estes modos de ver (MEYER; SOARES, 2005, p. 33).

Logo, ao optarmos pelo campo dos Estudos Culturais, como espaço aberto de articulação de saberes, conceitos e teorizações, estamos nos referindo há um espaço de conhecimentos plurais e transgressivos, onde "seus praticantes não buscam ser situação, mas (o)posição; não procuram tanto por consensos, mas travam batalhas e embates críticos consigo mesmos, com os saberes tidos como consolidados na Academia, com os entendimentos naturalizados acerca dos espaços educativos e dos sujeitos que neles habitam (BONIN et al., 2020, p. 2, grifos dos autores). Já a perspectiva pós-estruturalista, se apresenta como um estilo nada essencialista, homogêneo e ortodoxo de pensar, podendo ser caracterizado como um espaço filosófico que transcorre por múltiplos vetores, dando primazia a diferença e a desconstrução ${ }^{15}$ (WILLIAMS, 2012).

15 Conforme Derrida e Roudinesco (2004, p. 9, grifo dos autores), "desconstruir é de certo modo resistir à tirania do Um, do logos, da metafísica (ocidental) na própria língua em que é enunciada, com a ajuda do próprio material deslocado, movido com fins de reconstruções cambiantes". 
Inspirados por ambos os campos supracitados, esse texto, ainda, se configura como uma tentativa ensaística de (re)pensar as culturas infantis no que tange a sua relação com as tecnologias digitais no mundo contemporâneo. Por ensaio, aliado a Jorge Larrosa (2004, p. 32), entende-se

a forma não regulada da escrita e do pensamento, sua forma mais variada, mais protéica, mais subjetiva. Poder-se-ia dizer, talvez, que o ensaio é uma atitude existencial, um modo de lidar com a realidade, uma maneira de habitar o mundo, mais do que um gênero da escrita [...] e o modo experimental, por último, da vida, de uma forma de vida que não renuncia a uma constante reflexão sobre si mesma, a uma permanente metamorfose.

Ainda, Larrosa (2004), entende que o ensaio precisa ser abarcado como um modo de comunicar a vida pela linguagem, ao ponto de fabricar uma forma específica de relacionar a existência, o pensar, a subjetividade e a pluralidade. Destarte, inspirado em Cannavô (2021, p. 29), "uma pesquisa sempre nasce de uma inquietação, de um porquê. É exatamente por estarmos insatisfeitos com a resposta que temos no momento que perguntamos". Ainda, é exatamente renunciando a verdades absolutas e tornando estranho aquilo que era natural outrora que podemos problematizar os nossos objetos de pesquisa (CANNAVÔ, 2021). Assim, emerge como problema de pesquisa ensaístico desse texto a seguinte pergunta: de que modo se constitui a infância em tempos digitais? como os sujeitos, incluindo e sobretudo as crianças, mas também o complexo relacional adultos-sociedade, estão posicionados e interagem com as tecnologias digitais?

\section{TENSIONAMENTOS ACERCA DAS CRIANÇAS EM TEMPOS DIGITAIS}

A criança contemporânea está permeada pelos impactos tecnológicos que não experimentávamos em outros tempos. Muitas expectativas são projetadas a partir das relações com os adultos. Tais relações influenciam a ação das crianças com as tecnologias digitais que utilizam durante o seu cotidiano. Além disso, debater a questão das tecnologias digitais no agir das crianças permite lançar um novo olhar sobre o conhecimento social gerado pelas tecnologias nas relações 
entre os diversos sujeitos, práticas, construções humanas e contingências contemporâneas. Os modos de interação entre sujeitos e tecnologias digitais pautam o modo como cada sujeito é subjetivado pela e na cultura digital. Isto é, a destituição de orientação e exploração conjunta com os adultos, por exemplo, molda corpos infantis de forma distinta e singular conforme os atravessamentos específicos.

Numa sociedade tão espetacularizada e consumista como a nossa, o espaço do encontro, da escuta sensível, do sentido da autocriação na infância, do brincar, dos pensamentos, das emoções, dos sentimentos, dos diálogos etc. com o outro divide espaço com a visibilidade das telas, podendo tonificar ou não certos usos e relações entre sujeitos e tecnologias. Elas atraem professores e estudantes pela sensibilidade e imaginação, pois criam um universo de percepção por meio da fruição dos sentidos, que é a fonte da felicidade (HAN, 2017). Evidentemente, numa sociedade em que enfrentamos diversas dificuldades em diferentes âmbitos da vida, as tecnologias podem se tornar uma válvula de escape, pois são uma fonte de fascinação e distração por longo tempo. Neste caso,

As crianças e os mais jovens parecem apreciá-las especialmente, motivo pelo qual se dedicam a tais atividades com maior fervor ainda. Muitas vezes o fazem, inclusive, driblando as eventuais proibições das hierarquias escolares; aliás, não é raro que costumem recorrer a essas conexões para sobreviver ao tédio que implica ter que passar boa parte de seus dias encerrados em salas de aula, mais desesperadamente desconectados que disciplinadamente confinados (SIBILIA, 2020, p. 33).

No que tange à necessidade do debate, cabe refletir por quê a sociedade tem subestimado esses impactos citados pelos autores na cultura infantil, e como as crianças estão se formando e se reinventando de tempos em tempos. Percebe-se que a concepção de sociedade, sob a perspectiva do olhar adultocêntrico sobre a infância, circula e retoma práticas sociais que envolvem as crianças para que continuem tendo o mesmo papel de séculos atrás, ou seja, "o de matéria-prima para a produção de uma população adulta" (QVORTRUP, 2010, p. 787), e isso é visível nos discursos de pais, professores, escolas, enfim, da cultura em geral. 
É por isso que sempre nos referimos a elas como nosso futuro ou como a próxima geração. Essa maneira de falar levanta inevitavelmente a suspeita de que a infância não é nosso alvo principal, mas apenas um instrumento para outras propostas. É uma resposta à pergunta que todos os adultos fazem a todas as crianças: o que você vai ser quando você crescer? Tipicamente, os adultos não estão interessados no que as crianças são enquanto crianças (QVORTRUP, 2010, p. 787).

As tecnologias digitais possibilitam múltiplas formas de interação com o mundo e com o conhecimento. As crianças são parte deste fenômeno, portanto, percebe-se que novas infâncias estão surgindo, mediadas pelos constructos culturais, inclusive pelas tecnologias, com outras características e maneiras de se relacionar. A propagação dos artefatos tecnológicos na vida das crianças é um acontecimento recente e, em muitas localizações, ela ainda não se faz presente. Contudo, a rapidez com que essa difusão vem acontecendo, é inspiração para se produzir conhecimentos sobre esse assunto. Neste âmbito, diversos autores vêm se destacando, cada qual descrevendo de forma diferenciada seus conceitos e traçando o contexto de cada um em suas produções, assim como as contradições presentes nessas perspectivas: cyberinfância (estudos de Dornelles); infância hiper-realizada (estudos de Narodowski); infância midiática e geração eletrônica (estudos de Buckingham); infância virtual (estudos de Levin); geração-net (estudos de Don Tapscott); Geração Z e Homo Zappiens (estudos de Vrakking e Veen), dentre outros.

A partir deste panorama de denominações e autores, arriscamos e optamos a intitulá-la de cyberinfância descrita por Dornelles (2005) para tecer algumas reflexões, pois a autora apresenta um conceito mais abrangente, uma vez que engloba a cultura proporcionada pelas transformações das tecnologias e as culturas infantis. A ciberinfância refere-se às crianças que lidam com as tecnologias, sendo essa apenas uma das diferentes infâncias que constituem a nossa sociedade (DORNELLES, 2005). Em suas investigações sobre os discursos da infância globalizada na contemporaneidade, Dornelles (2005) denomina de cyberinfância. Para a autora, a cyberinfância é vista como um perigo para os adultos, de modo que causa neles um sentimento de medo. 
Vê-se na cyber-infância um perigo, talvez por não se ter produzido um saber suficiente para controlá-la ou porque não conseguem melhor governá-la. Discursos que produzem efeitos de verdade e acabam se tornando verdades incontestáveis. Talvez, por isso se tenha a necessidade de tratar as crianças da cyber-infância como anormais (DORNELLES, 2005, p. 84).

A autora compreende que essa infância nos escapa ${ }^{16}$, tendo em vista que as crianças que lidam com as diversas tecnologias de forma espontânea instintiva, dando a sensação que elas estão escapando do nosso controle, do controle dos adultos. Dornelles (2012, p. 94) destaca a necessidade de investigar mais as reverberações dos artefatos culturais que fazem parte do cotidiano das crianças:

Atualmente, também são produzidos, além dos espaços de shopping, novos artefatos de consumo e lazer para as crianças como parques temáticos, os resorts, os clips de músicas e filmes e, também, a todo momento se reorganizam, os museus, a mídia, as lojas de departamento, os estádios esportivos, etc., para atender este novo consumidor infantil. Nesses espaços, se fabricam o prazer, os desejos, as emoções, as descobertas e as perturbações da infância contemporânea. [...] Ou seja, inventam-se novas formas de disciplinamento não só sobre os corpos das crianças, mas também sobre seus desejos.

As crianças, desde muito cedo, são percebidas como consumidoras em potencial. De acordo com Narodowski (2013), ao referir-se às infâncias atuais, localiza-as em dois polos: em um polo, estaria o que ele denomina de infância hiper-realizada, ou seja, a infância 3.0, aquelas crianças que possuem acesso à internet, aos dispositivos eletrônicos, aos diversos canais de TV por assinatura e aos videogames e que, portanto, ao invés de serem conduzidas pelos adultos, agora são seus próprios "professores" nessa cultura digital. De acordo com Narodowski (2013, p. 11), fazem parte desta infância hiper-realizada, no sentido de que as crianças,

16 De acordo com Larrosa (1998, p. 232), "Se a presença enigmática da infância é a presença de algo radical e irredutivelmente outro, ter-se-á de pensá-la na medida em que sempre nos escapa: na medida em que inquieta o que sabemos (e inquieta a soberba de nossa vontade de saber), na medida em que suspende o que podemos (e a arrogância da nossa vontade de poder) e na medida em que coloca em questão os lugares que construímos para ela (e a presunção da nossa vontade de abarcá-la). Aí esta a vertigem: no como a alteridade da infância nos leva a uma região em que não comandam as medidas do nosso saber e do nosso poder". 
conectadas 24 horas al día a los diversos dispositivos al que tienen acceso: smartphones, tablets, smartTV, consolas de videojuegos por mencionar solo algunos. Niños digitales a los cuales les es imposible imaginarse un mundo en que la información, y el mundo mismo no estén al alcance de su mano a través de Internet. Niños que viven en la más absoluta inmediatez, en la realización inmediata del deseo. Niños que son maestros de sus padres, de sus maestros. Niños que parecerían no necesitar más la protección del adulto o mirando la otra cara de la moneda, no generan demasiada necesidad de protección por parte de los adultos.

Narodowski (2013) aponta que a infância hiper-realizada não necessita mais ter a expectativa em chegar à vida adulta para a plena concretização dos seus diversos desejos, pois as crianças que fazem parte desta cultura possuem, desde muito cedo, acesso a artefatos como tela touchscreen, tutoriais, computadores, celulares dentre outros artefatos que aprendam rapidamente a manusear.

Também em relação à infância hiper-realizada, Narodowski (2013) aponta para os conhecimentos acumulados ao longo da vida pelos mais velhos, que antigamente eram partilhados com os mais jovens e eram aproveitados como referências, e que atualmente estão sendo transferidos ao passo que estão disputando, de forma acentuada com os hiperlinks de acesso à Wikipédia (enciclopédia virtual livre), que cada vez mais é acessada pela geração que o autor chama de screenagers, categoria que emprega para se referir aos teenagers e às telas touchscreen. De acordo com Narodowski (2013, p. 29),

Hoy los niños son emperadores mediáticos. Control remoto en mano hacen zapping de cientos de canales que tienen disponibles con solo un click. Acceden tanto a canales exclusivos para ellos (inclusive ya se disponen canales para bebés como BabyFirstTV [...] Niños que transcurren sus días entre pantallas. Pantallas de televisión, pantallas de videojuegos, de tablets o de notebooks en la escuela. Smartphones indispensables para no desconectarse ni un segundo. Aún con canales como Disney Channel o Disney Extreme transmitiendo 24 horas al día el aburrimiento está a la orden del día. Ya no hay que esperar por la hora de ese programa favorito que se seguía desesperadamente. Ya no existe el temor al castigo de no poder mirar televisión. Hoy el peor de los castigos sería desconectarlos. 
acesso aos diversos artefatos tecnológicos e mídias, de modo que o pior castigo seria a privação das conexões. Do outro lado, estão as infâncias desrealizadas, que vivem na rua, que trabalham, as que são pobres. A compreensão de infância desrealizada possa ser sintetizada a partir desta explicação de Narodowski (2013, p. 30):

Son niños que nos cuesta definir como tales, ya que no nos despiertan aquellos sentimientos de protección y de ternura que debieran despertarnos. Son niños que no están infantilizados. Son niños que trabajan, que piden en las calles, que viajan de un lado a otro en búsqueda de algún refugio dónde dormir. Son niños con recursos necesarios para no depender de un adulto, y adultos que no ven la necesidad de protegerlos. Buscan sus propios alimentos, no rinden cuentas a nadie y adquieren sus propias categorías morales de la calle.

A infância desrealizada não teria acesso facilitado aos artefatos tecnológicos e à conexão de internet. Ou seja, são crianças que vivem num universo off-line que dificilmente possuem acesso à internet. Assim, são crianças que vivem nas ruas, à margem da sociedade e de suas instituições. Então, conforme Narodowski (2013), seria entre esses dois polos que poderíamos situar grande parte das crianças na contemporaneidade. Vale mencionar que não se trata de afirmar que existem apenas essas duas formas de ser criança, mas de indicar que há uma multiplicidade de crianças que vivem entre esses dois polos definidos pelo pesquisador e que vivenciam diversas transformações ocorridas na atualidade e nos novos modos de viver e de significar a infância. Conforme apontam dados da Unicef ${ }^{17}$, a partir do relatório How Many Children and Youth Have Internet Access at Home? (2020, online, tradução nossa), "dois terços das crianças em idade escolar no mundo não têm acesso à internet em casa". As crianças em idade escolar na África Subsaariana e na Ásia Meridional são as mais afetadas no globo, com índices de 9 a cada 10 crianças não tendo nenhum tipo de acesso à internet (UNICEF, 2020, online).

17 "Globalmente, entre as crianças em idade escolar das famílias mais ricas, 58\% têm conexão à internet em casa, em comparação com apenas $16 \%$ das famílias mais pobres. A mesma disparidade também existe entre os níveis de renda do país. Menos de 1 em cada 20 crianças em idade escolar de países de baixa renda têm conexão com a internet em casa, em comparação com quase 9 em cada 10 crianças em países de alta renda" (UNICEF, 2020, online). 
De acordo com Buckingham (2007, p. 20, grifo do autor), os adultos sempre monopolizaram o poder de definir a infância, e suas "definições são codificadas em leis e políticas, e se materializam em formas particulares de práticas sociais e institucionais, que, por sua vez, ajudam a produzir as formas de comportamento vistas como tipicamente 'infantis'”. Contudo, a infância descrita e idealizada pela modernidade vem sendo problematizada, pois não existe apenas a infância, e sim múltiplas infâncias, múltiplos modos de ser criança, e atentam para as formas de poder praticadas sobre as crianças. Como afirma Buckingham (2007, p. 19), a infância "é variável - histórica, cultural e socialmente variável. As crianças são vistas - e veem a si mesmas - de formas muito diversas em diferentes períodos históricos, em diferentes culturas e em diferentes grupos sociais". Por isso, não pode mais ser vista como determinada biologicamente, nem ser descrita em um único conceito fechado e universal. Na visão de Dornelles (2005, p. 71),

Se vive sob o efeito da produção da infância moderna, contudo não é mais possível se tratar de uma só infância como a preconizada pela Modernidade. É preciso pelo menos que se leve em consideração que existem muitas outras infâncias. Existem infâncias mais pobres e mais ricas, infâncias do Terceiro Mundo e dos países mais ricos, infâncias da tecnologia e a dos buracos e esgotos, infâncias superprotegidas, abandonadas, socorridas, atendidas, desamadas, amadas, armadas etc.

Dessa forma,

[...] as culturas da infância, sendo socialmente produzidas, constituem-se historicamente e são alteradas pelo processo histórico de recomposição das condições sociais em que vivem as crianças e que regem as possibilidades das interações das crianças, entre si e com os outros membros da sociedade. As culturas da infância transportam as marcas dos tempos, exprimem a sociedade nas suas contradições, nos seus estratos e na sua complexidade (SARMENTO, 2003, p. 54).

Nessa perspectiva, Momo e Costa (2010) corroboram que mesmo as crianças ditas com baixo poder aquisitivo são atravessadas pelas práticas de consumo e por uma gramática tecnológica.

Observamos que mesmo uma criança que não tem saneamento básico em casa é capaz de saber detalhes sobre o uso e o funcionamento de notebooks, celulares e iPods tanto quanto adultos ou quanto crianças de condições econômicas privilegiadas. Aprendem na mídia (principalmente 
televisiva) e na vida pelas metrópoles a dominar uma certa "gramática" da cultura tecnológica que empregam para pensar e viver. São crianças high tech por um certo tipo de impregnação cultural. Estão sempre obtendo novas informações sobre o universo tecnológico, o que marca seu modo de viver por uma constante mutação. Muitas delas ofereciam-se e desejavam permanecer o tempo todo como monitoras voluntárias do uso dos computadores existentes em laboratórios de informática de algumas escolas públicas. Outras se familiarizam com a tecnologia sendo frequentadoras assíduas das lan houses singelas dos bairros e vilas periféricas que habitam (MOMO; COSTA, 2010, p. 976-977).

Momo e Costa (2010) acrescentam, a partir de Bauman (2008), que a sociedade de consumo se esforça para capacitar todos os sujeitos, incluindo as crianças que supostamente estariam fora dessa rede de consumo para se tornarem consumidoras. Momo e Costa (2010) reafirmam que as crianças parecem sempre estar em estado de alerta e de prontidão para o consumo, em função do acesso cada vez mais efetivo aos últimos lançamentos de brinquedos e às últimas invenções tecnológicas. Para além das apropriações técnicas e da utilização pelas crianças dos diferentes artefatos, Momo e Costa (2010) chamam atenção para a necessidade de se observar que todas as produções midiáticas voltadas para as crianças são também atravessadas, ou ainda, impregnadas de estímulos para o consumo não apenas de produtos, mas de diferentes pedagogias.

Dentro de um sistema capitalista-consumista, as possibilidades de fuga são escassas. Ao estarem inseridas neste espaço, as crianças são convocadas a participar desse processo de ordem consumista. Percebemos "não só nas roupas e adereços que elas usam, mas no valor que dão ao fato de poderem adquirir moda [...] e no quanto são atraídas e usadas pelas estratégias de convocação ao consumo levadas a efeito pela publicidade" (ANDRADE; COSTA, 2010, p. 234-235). Dessa forma, a indústria busca estratégias para capturar as crianças endereçadas, concedendo protagonismo a elas tendo em vista o seu papel potencial na sociedade, seja pelo consumo ou pelo governo dos corpos. Segundo Quinteiro (2002, p. 21),

[...] pouco se conhece das culturas infantis porque pouco se ouve e pouco se pergunta às crianças e, ainda assim, quando isto acontece, a "fala" apresenta-se solta no texto, intacta, à margem das interpretações e aná- 
lises dos pesquisadores. Estes parecem ficar prisioneiros de seus próprios referenciais de análise. Entre as ciências da educação, no âmbito da sociologia, há ainda resistência em aceitar o testemunho infantil como fonte de pesquisa confiável e respeitável.

Trata-se da importância de se ouvir as crianças, para que desta forma possamos conhecer as culturas infantis, ou seja, viabilizando a escuta dessas vozes pautamos uma série de saberes pertinentes ao mundo das crianças e dos adultos. Vale ressaltar que são muito importantes os estudos que agreguem valor e deem visibilidade aos discursos das crianças, na tentativa de desvelar a rica matéria-prima que é interagir com as crianças. Entretanto, Felipe (2009, p. 8) aponta que ouvindo as crianças e inserindo-as como privilegiadas das pesquisas, não fará com que aconteça uma verdade natural e também absoluta sobre as crianças, de modo que "é ilusão pensar que 'dar' voz às crianças, observando atentamente os discursos que elas produzem ou reproduzem sobre si mesmas e o mundo nos trará um desvelar sobre a infância". Silveira (2002, p. 80) diz que ao ouvir as crianças, abre-se a possibilidade de interação com um conjunto de vozes, o que requer ouvir todas as manifestações, as diferentes interlocuções, pois, "os discursos são atravessados por outros discursos, as vozes que ouvimos ecoam outras vozes". Assim, as falas das crianças precisam ser analisadas como os outros textos culturais. Na linha de investigação de Steinberg e Kincheloe (2004, p. 34),

As crianças pós-modernas não estão acostumadas a pensar e agir como criancinhas que precisam da permissão do adulto para tal. Entendemos que nem todas as crianças reagem à cultura infantil e seu acesso à cultura popular desta forma, pois diversos grupos de crianças responderão diferentemente. A realidade que fica, no entanto, é que os adultos perderão a autoridade que tinham antes por saberem coisas que as crianças, propositalmente protegidas, não sabiam. A informação adulta é incontrolável; agora, a criança vê o mundo como ele é (ou pelo menos como é descrito pelos produtores de informação corporativos).

Alguns grupos sociais convivem desde a infância com as (in)visibilidades atrativas das mídias, desde o controle remoto, o mouse e o celular. Tais artefatos são extensões do próprio corpo e servem também para trocarmos, discutirmos e 
articularmos saberes. Segundo Felipe (2006, p. 253),

Em relação à infância, a construção das identidades articula-se aos discursos a respeito da criança que são veiculados e sustentados por diversos artefatos culturais. Dentre tais artefatos, a mídia vem ocupando lugar de destaque nos últimos tempos, na medida em que veicula uma gama enorme de informações sobre os mais variados assuntos. Tais informações mostram desde modos de ser criança até do que devem gostar e como devem proceder.

Na verdade, já nasceram em um contexto de mídias digitais, fazendo parte de uma cultura participativa (JENKINS, 2009). Tamanha é essa transformação que não basta a nos colocarmos ante a essa realidade como espectadores fascinados, mas precisamos analisar as ressonâncias nas nossas vidas, mudanças em nossas visões de mundo, especialmente nas culturas das infâncias. De acordo com Melo e Guizzo (2019, p. 124), "é possível afirmar que a cultura participativa se refere à forma como a sociedade contemporânea (em função da popularização da Internet) tem se distanciado da condição de receptora passiva". Além disso,

Se, de um lado, é certo que a criança, ao invés de absorver ou consumir passivamente os objetos e as informações disponíveis nessa rede, atua como leitora e construtora de significados e conexões entre as narrativas que nela circulam, como se ordenasse e reordenasse as peças de um quebra-cabeça polimorfo, de outro, é importante considerar que essa mesma criança, para ser bem sucedida nessa tarefa, deve estar atenta e a par de cada nova informação e produto lançado na rede, exigindo de si próprio e dos outros com quem compartilha, atitude empreendedora, atualização e expertise (SOUSA; SALGADO, 2009, p. 213).

As crianças sempre reproduziram o mundo dos adultos a partir de brincadeiras de faz de conta, dos modos de ser, de pensar e de agir, que envolvem sociabilidades e temas relacionados aos adultos, assim, "a criança contemporânea se constitui pelo desejo de saber e é fortemente influenciada por diferentes mídias" (OLIVEIRA et al., 2019, p. 38). Contudo, no contexto contemporâneo, as crianças não são mais pensadas como dependentes dos adultos, tanto na esfera econômica e política, como na esfera mais restrita do âmbito familiar e escolar, até porque, o mercado concedeu lugar para as crianças, tendo suas histórias interligadas com as mudanças das relações entre adultos e crianças 
(PEREIRA, 2002). De acordo com Fischer (2002, p. 153), "torna-se impossível fechar os olhos e negar-se a ver que os espaços da mídia constituem-se também como lugares de formação - ao lado da escola, da família, das instituições religiosas". Segundo Momo e Costa (2010, p. 972), "no caso da infância, mais do que as marcas, são os ícones infantis mercantilizados que constituem o valor dos artefatos". A infância tida enquanto fase de inocência, incerteza, dependência e ignorância do mundo parece estar rapidamente desaparecendo, e "no lugar dela instalam-se as infâncias dos tempos pós-modernos, insondáveis, múltiplas, instáveis, paradoxais, selvagens, incontroláveis, enigmáticas" (MOMO; COSTA, 2010, p. 988-989).

Enquanto artefatos de produção de subjetividades infantis, os discursos produzidos em torno das crianças (re)produzem as próprias representações dos adultos, pois são elaboradas e naturalizadas pela linguagem humana, recebendo significados na cultura com potencial de subjetivar as crianças. Afinal, "tal como a educação, as outras instâncias culturais também são pedagógicas, também têm uma pedagogia, também ensinam alguma coisa. Tanto a educação quanto a cultura em geral estão envolvidas em processos de transformação da identidade e da subjetividade" (SILVA, 2017, p. 139, grifo do autor). Os contextos socioeducacionais informais, neste caso, as tecnologias influenciam na construção da identidade da criança, uma vez que as mídias, por meio da publicidade, favorecem o consumismo e a produção das subjetividades desde a infância. Nesse âmbito, as crianças comunicam-se por meio de expressões, dos movimentos do corpo, dos afetos e das feições, por isso são capazes de manifestar seus saberes e interesses, de modo que precisam ser valorizadas pelas suas formas de expressão e capacidade de articular aprendizagens.

Levando em consideração a força da cultura de massa, as tecnologias digitais veiculam sentidos e significados produzidos que conduzem os sujeitos para o fascínio, consolidando verdades que buscam apresentar sobre perspectivas de vida, sobre ser e estar no mundo. Estes artefatos formam um campo de produção de subjetividades, por isso que as interações dos sujeitos com as mídias 
se apresentam como importantes objetos para questionamento e investigação (CASTRO, 1999). Assim, é necessário questionar sobre os efeitos que os discursos produzem na forma como os sujeitos constroem seus sentidos nas suas existências.

Estas novas tecnologias culturais infantis exigem que se invista em pesquisas sobre os cyber-infantes e sobre as tecnologias e estratégias criadas para se produzir o sujeito infantil da contemporaneidade. É preciso que se possa pensar problematizando as relações entre a infância e o mundo atual digitalizado ao qual os cyber-infantes têm acesso desde que nascem. Precisa-se aprender sobre o modo como as crianças e os adolescentes lidam com estes equipamentos eletrônicos; sobre as formas de enclausuramento dos infantis na atualidade que não mais usam outros espaços da casa ou da rua para suas atividades, mas sim os shoppings, o de seus quartos informatizados, os seus lan house (DORNELLES, 2005, p. 85).

A contemporaneidade apresenta cada vez mais mídias digitais que geram mudanças nas formas de ler textos, de assistir filme e de navegar na internet, assim como requer novas compreensões das culturas de infâncias e mídias digitais, as subjetividades produzidas e das formas conectadas de conviver e agir das famílias e dos demais sujeitos frente às ações e inter-relações com as mídias digitais (CANCLINI, 2008). Nas palavras de Beck (2017, p. 37),

Tenho entendido por mídia as diversas formas que pessoas e instituições têm se utilizado para estabelecer comunicação, entretenimento e educação. A mídia se converte como uma instância pedagógica com elevado poder educativo na vida das pessoas, sendo concebida como produtora de significados. Notadamente, atrelada ao consumo como condição de emergência e possibilidade, a mídia se posiciona como espaço pedagógico ensinando, a adultos e crianças, modos de ser, viver, conviver, agir, estando cada vez mais próxima desses sujeitos. Na profícua associação estabelecida entre sentimentos, artefatos e vida, a mídia se revela complexa e abrangente.

Segundo Fischer (2006), a mídia é um potente espaço social produtor de significados e identidades que ultrapassam as superficiais fronteiras da informação, entretenimento e lazer da vida cotidiana. Por meio de um conjunto de expressões de conhecimentos e saberes, as mídias são consideradas na contemporaneidade como um dos principais e mais importantes âmbitos que formam um conjunto polissêmico de significados na vida das pessoas. Na verdade, as mídias 
não somente fazem uso dos discursos e representações sociais e culturais, mas são capazes de (co)criar, (re)inventar e (re)produzir formas de ser e estar. Enquanto possibilidades de uso desfrutam de imagens, ícones, símbolos e sujeitos por onde circulam variados ensinamentos (BECK, 2017).

\section{CONSIDERAÇÕES FINAIS}

A partir das problematizações tensionadas na seção anterior, saímos em defesa da pluralidade dos modos de pensar os sujeitos, no caso desse texto, das crianças em relação as tecnologias digitais. As noções de infância e de criança não são homogêneas nem unitárias, mas vem passando por uma série de transformações no seio da cultura, pautadas nas negociações de significados através da linguagem, especificamente no que se trata das suas devidas relações com as tecnologias digitais. Logo, os choques culturais incidem sobre os sujeitos, os espaços e os artefatos a partir de uma rede de relações de poder que ocasionam nas contestações dos significados e lhes atribuem novos modos de ser, estar e pensar.

No momento em que tensionamos os significados, no que tange a criança, estamos também indicando as maneiras mais adequadas de educa-las, ao passo que apontamos também para que tipo de sujeito-criança ideal queremos formar (SCHÉRER, 2009). Ou seja: no momento em que discutimos a infância, seja com qual interface for, estamos inventando-a. Também, vale ressaltar que o modo como se educa a criança "desempenha um papel-chave atualmente, da publicidade à polícia, [onde] tudo se pedagogiza" (SCHÉRER, 2009, p. 27). Discutir a criança é, a fortiori, fabricá-la. Sendo assim, notadamente, as crianças que habitam o mundo em tempos digitais, sejam as nativas e usuárias dessas redes sociais, que gozam dos (des)prazeres desse meio, sejam as excluídas e sem acesso, que também gozam dos (des)prazeres da não-interação, são compreendidas como um campo de disputa (pela linguagem, pelo capitalismo, pela religião, pelo Estado, pela escola etc.) com potencial de captura. 
Por fim, com base no que discutimos durante o texto, percebe-se que plurais são os modos de pensar as crianças e as tecnologias digitais. De fato, muitos são os modos como os sujeitos estão posicionados na sociedade, inclusive em tempos digitais. Muitos são os modos de pensar porque muitas são as interações possíveis entre crianças e tecnologias, não podendo ser circunscritas e delimitadas por apenas um ou dois modos de pensar, pois essas crianças estão inseridas em um complexo de situações que povoam o cotidiano delas. Com isso, vale ressaltar que as crianças estão marcadas pela difusão das diferentes tecnologias digitais e pela vontade de conexão a internet - ou até pela ausência de possibilidade de acesso.

\section{REFERÊNCIAS}

ANDRADE, Paula Deporte de; COSTA, Marisa Vorraber. Usando crianças para vender: infância e consumo na publicidade de revistas. Revista Reflexão e Ação, Santa Cruz do Sul, EDUNISC, v.18, n2, p.230-248, jul./dez. 2010.

BAUMAN, Zygmunt. Modernidade Líquida. Rio de Janeiro: Zahar, 2008.

BECK, Dinah Quesada; ESPERANÇA, Joice Araújo (Orgs.). Mídia e consumo: pedagogias culturais de investimento na infância. In: BECK, Dinah Quesada. Infâncias em foco: mídia, consumo e artefatos da cultura contemporânea. Coleção Cadernos Pedagógicos da EaD. Volume 27. Rio Grande: Ed. da FURG, 2017. p. 37-56.

BONIN, lara et al. Por Que Estudos Culturais?. Educação e Realidade, Porto Alegre, v. 45, n. 2, p. 1-22, maio/ago., 2020.

BUCKINGHAM, David. Crescer na era das mídias eletrônicas. Tradução de Gilka Girardello e Isabel Orofino. São Paulo: Loyola, 2007.

CANCLINI, Néstor Garcia. Culturas Hibridas: estratégias para entrar e sair da modernidade. São Paulo: USP, 2008.

CANNAVÔ, Vinícius. Pedagogias do Rap e a narrativa insurgente: uma análise a partir das composições musicais do rapper Djonga. 2021. 170f. Dissertação (Mestrado em Educação) - Universidade Federal do Rio Grande do Sul, Porto Alegre, 2021. 
CASTRO, Lucia Rabello de (Org.). Infância e adolescência na cultura do consumo. Rio de Janeiro: Nau, 1999.

DERRIDA, Jacques; ROUDINESCO, Elizabeth. De que amanhã.... diálogos. Rio de Janeiro: Jorge Zahar, 2004.

DORNELLES, Leni Vieira. Infâncias que nos escapam: da criança na rua à criança cyber. Petrópolis: Vozes, 2005.

DORNELLES, Leni Vieira. Artefatos Culturais: ciberinfâncias e crianças zappiens. In: DORNELLES, Leni Vieira; BUJES, Maria Isabel Edelweiss. Educação e infância: na era da informação. Porto Alegre: Mediação, 2012. p. 79-102.

FELIPE, Jane. Representações de gênero, sexualidade e corpo na mídia. Revista Tecnologia e Sociedade, Curitiba, v. 2, n. 3, p. 251-264, 2006. DOI: 10.3895/ rts.v2n3.2490

FELIPE, Jane. Estudos Culturais, gênero e infância: limites e possibilidades de uma metodologia em construção. Textura, Canoas, n. 19-20, p. 4-13, 2009.

FISCHER, Rosa Maria Bueno. Verdades em suspenso: Foucault e os perigos a enfrentar. In: COSTA, Marisa Vorraber (Org.). Caminhos Investigativos II: outros modos de pensar e fazer pesquisa em educação. Rio de Janeiro: DP\&A, 2002. p. 49-71.

FISCHER, Rosa Maria Bueno. Televisão e educação: fruir e pensar a TV. Belo Horizonte: Autêntica, 2006.

FOUCAULT, Michel. Subject and the Power. In: DREYFUS, Hubert; RABINOW, Paul. Michel Foucault: Beyond Structuralism and Hermeutics. Chicago: University of Chicago Press, 1993.

HAN, Byung-chul. Sociedade do cansaço. Trad. Énio Paulo Giachini. 2. ed. Petrópolis, RJ: Vozes, 2017.

JENKINS, Henry. Cultura da convergência. 2. ed. São Paulo: Aleph, 2009. 
LARROSA, Jorge. A Operação Ensaio: sobre o ensaiar e o ensaiar-se no pensamento, na escrita e na vida. Educação \& Realidade, Porto Alegre, v. 29, n. 1, p. 27-43, jan./jun. 2004.

LARROSA, Jorge. Pedagogia Profana. Porto Alegre: Contrabando, 1998.

MELO, Darcyane Rodrigues de; GUIZZO, Bianca Salazar. Infância YouTuber: problematizando representações de crianças inseridas na cultura de sucesso. Série-Estudos, Campo Grande, MS, v. 24, n. 50, p. 121-140, jan./abr. 2019.

MEYER, Dagmar Elisabeth Estermann; SOARES, Rosângela de Fátima. Modos de ver e de se movimentar pelos "caminhos" da pesquisa pós-estruturalista em Educação: o que podemos aprender com - e a partir de - um filme. In: COSTA, Marisa Vorraber; BUJES, Maria Isabel Edelweiss (Orgs.). Caminhos Investigativos III: riscos e possibilidades de pesquisar nas fronteiras. Rio de Janeiro: DP\&A, 2005, p. 23-44.

MOMO, Mariangela; COSTA, Marisa Vorraber. Crianças escolares do século XXI: para se pensar uma infância pós-moderna. Cadernos de Pesquisa, São Paulo, v.40, n.141, p.965-991, set./dez. 2010.

NARODOWSKI, Mariano. Hacia un mundo sin adultos. Infancias híper y desrealizadas en la era de los derechos del niño. Actualidades Pedagógicas, p. 15-36, 2013.

OLIVEIRA, Cláudia de et. al. Infância e tecnologias: desafios e relações aprendentes. Textura, Canoas, v. 21, p. 37-58, 2019. DOI: 10.17648/textura-2358-0801-21-46-4542

PEREIRA, Rita Marisa Ribes. Infância, televisão e publicidade: uma metodologia de pesquisa em construção. Cadernos de Pesquisa, São Paulo, n.116, p. 235264 jul./2002.

QUINTEIRO, Jucirema. Infância e Educação no Brasil: um campo de estudos em construção. In: DEMARTINI, Zeila de Brito Fabri; FARIA, Ana Lúcia Goulart de; PRADO, Patrícia Dias (Orgs.). Por uma cultura da infância: metodologia de pesquisa com crianças. Campinas, São Paulo: Autores Associados, 2002. p. 19-47. 
QVORTRUP, Jens. Nove teses sobre a infância como fenômeno social. Pro-Posições, Campinas, v. 22, n. 1, p. 199-211, 2011. DOI: 10.1590/S010373072011000100015

SCHÉRER, René. Infantis: Charles Fourier e a infância para além das crianças. Belo Horizonte: Autêntica Editora, 2009.

SARMENTO, Manuel. Imaginário e culturas da infância. Cadernos de Educação,v. 12, n. 21, 51-69, 2003.

SIBILIA, Paula. Do confinamento à conexão: as redes infiltram e subvertem os muros escolares. In: SALES, Mary Valda Souza (Org.). Tecnologias digitais, redes e educação: perspectivas contemporâneas. Salvador: EDUFBA, 2020, p. 29-40.

SILVA, Tomaz Tadeu da. Documentos de identidade: uma introdução às teorias de currículo. Belo Horizonte: Autêntica Editora, 2017.

SILVEIRA, Rosa Hessel. Olha quem está falando agora! A escuta das vozes em educação. In: COSTA, Marisa (org.). Caminhos investigativos: novos olhares na pesquisa em educação. Rio de Janeiro: DP\&A, 2002. p. 61-83.

SOUSA, Solange Jobim; SALGADO, Raquel Gonçalves. A criança na idade mídia - Reflexões sobre cultura lúdica, capitalismo e educação. In: SARMENTO, Manuel; GOUVEA, Maria Cristina Soares de (Orgs.). Estudos da Infância: educação e práticas sociais. Petrópolis: Vozes, 2009. p. 207-221.

STEINBERG, Shirlei R.; KINCHELOE, Joe L. Cultura infantil: a construção corporativa da infância. Tradução de George Eduardo Japiassú Brício, $2^{a}$ Ed. Rio de Janeiro: Civilização Brasileira, 2004.

UNICEF. How many children and young people have internet access at home?. dez./2020. Unicef for every child. Disponível em: <https://data.unicef. org/resources/children-and-young-people-internet-access-at-home-duringcovid19/>. Acesso em 12 set. 2021.

WILLIAMS, James. Pós-estruturalismo. Petrópolis: Vozes, 2012. 


\section{SOBRE O ORGANIZADOR}

\section{ADILSON GRISTIANO MABOWSRI}

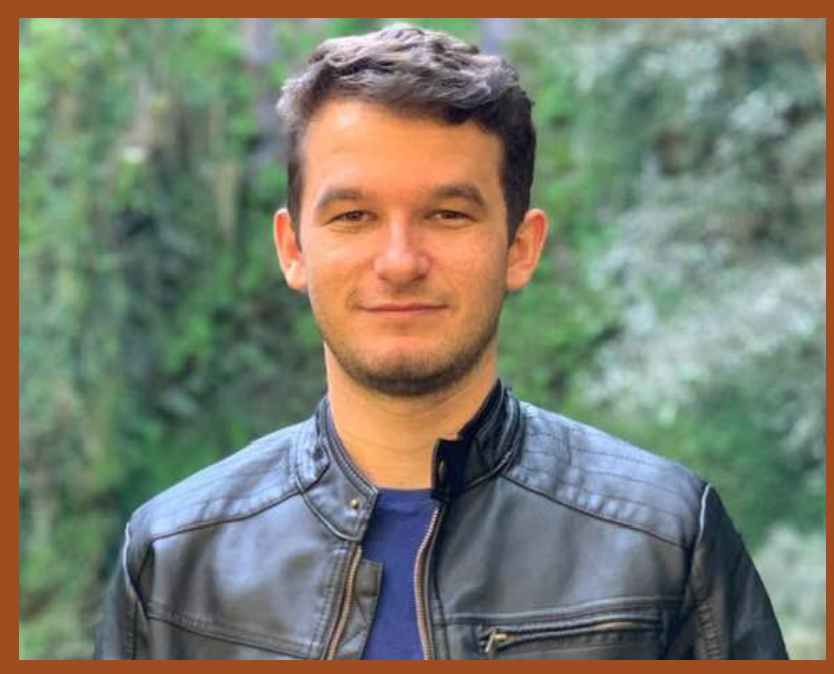

Doutorando em Educação na Universidade La Salle - Canoas/RS. Mestre em Educação pela Universidade La Salle - Canoas/RS. Possui o Ensino Médio na modalidade normal (Magistério), com habilitação para atuar como educador nas áreas de Educação Infantil e Séries Iniciais (2014); Graduação em Teologia pela Universidade La Salle - Canoas/ RS (2017); e Especialização em Docência no Ensino Superior: Práxis Educativa pela Universidade La Salle - Canoas/RS (2019). Tem dezenas de artigos publicados na área da Educação em periódicos científicos com indexação nacional e internacional, e autor (e organizador) de livros nas interfaces de Educação e Tecnologias. Dentre os livros publicados, destaca-se "Tecnologias e educação: conhecer o outro lado", publicado pela Editora Appris (2020). Parecerista ad hoc de diversos periódicos nacionais na área da Educação. Tem experiência na organização de dossiês temáticos em periódicos científicos e de livros. Possui experiência prática nas áreas de: Educação Infantil, Séries Iniciais, Ensino Religioso e na área de Pastoral Escolar, com ênfase em Formação humana; professor conteudista e professor validador. Seus interesses e experiências em pesquisas estão principalmente nos seguintes temas: tecnologias e educação; infâncias e tecnologias.

CID: https://orcid.org/0000-0002-5378-7981

E-mail: adilsonhabowski@hotmail.com 


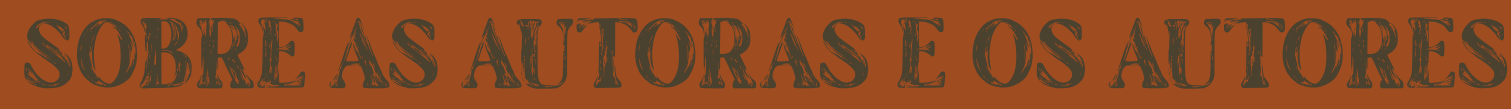

\section{Adilson Cristiano Habowski}

Doutorando e Mestre em Educação pela Universidade La Salle -Canoas/RS. ORCID: https://orcid.org/0000-0002-5378-7981

E-mail: adilsonhabowski@hotmail.com

\section{Ana Angélica de Souza Alencar}

Graduanda do Curso de Pedagogia da Universidade Federal do Pará.

E-mail: anaangelicasc@hotmail.com

\section{Antonella Tassinari}

É doutora em Antropologia pela Universidade de São Paulo. Leciona na Universidade Federal de Santa Catarina e orienta e desenvolve pesquisas no Núcleo de Estudos de Populações Indígenas - NEPI.

\section{Claudinéia Garcia Ferreira de Oliveira}

Especialista em Psicopedagogia, Educação Especial e Inclusiva, graduada em Licenciatura em Pedagogia pela Universidade Castelo Branco (UCB) Licenciatura em Educação Especial pela Universidade Federal de Santa Maria (UFSM), Experiência profissional na Educação Infantil, Ensino Fundamental, Educação Especial e Sala de Recursos Multifuncional. Professora efetiva na Rede Municipal de Foz do Iguaçu. Email claudigfo@hotmail.com

\section{Daniele Dorotéia Rocha da Silva Lima}

Doutora e Professora na Universidade Federal do Pará.

Email danidoroteia@ufpa.br

\section{Eliana Gristina Pereira Santos}

Doutoranda e Mestra em Letras: Linguagem e Sociedade da UNIOESTEUniversidade Estadual do Oeste do Paraná (Campus Cascavel), Coordenadora e professora do Curso de Pedagogia FAFIG-Faculdade de Foz do Iguaçu, Coordenadora Pedagógica SEED/PR - Secretaria Estadual de Educação do Estado do Paraná.

E-mail: eliana.foz@gmail.com

ORCID: https://orcid.org.0000-0002-2952-3513

Link Lattes: http://lattes.cnpq.br/9076626552542193 


\section{Gleide Gunha de Souza}

Especialista em Educação infantil, licenciada em pedagogia.

Email: educacaoinfantilsemed@yahoo.com

\section{Joaquina lanca Miranda}

Bolsista de Iniciação científica e graduanda do Curso de Licenciatura Plena em Pedagogia na Universidade Federal do Pará. E-mail: joaquinaianca@gmail.com.

\section{Keila Aparecida Duarte Rufino}

Mestre em Tecnologias, Comunicação e Educação pela Universidade Federal de Uberlândia (UFU). Professora da rede municipal de Uberlândia-MG.

E-mail:duarterufinok@gmail.com

\section{Maria Lucivane de Oliveira Morais}

Mestra em Filosofia Moderna e Contemporânea, pela Universidade Estadual do Oeste do Paraná (UNIOESTE), 2018. Licenciada em Geografia pela Faculdade União das Américas, 2007. Licenciada em Filosofia pela UNIOESTE, 2014. Especialista em Educação Especial, Métodos e técnicas do ensino de Geografia e História; Saúde do Professor, Educação: Métodos e técnicas do ensino, Neuroeducação, Gamificação. Professora efetiva da rede estadual do Paraná. Docente no curso de formação de professores oferecido pela Secretaria Estadual de Educação (SEED).

E-mail: maria_lucivane@hotmail.com.

\section{Maria Helena da Costa Bianchi}

Mestra em Ensino, Universidade Estadual do Oeste do Paraná (UNIOESTE), 2018. Licenciada em Letras/Espanhol pela Unioeste em 1997 e em Educação Especial pela Universidade Federal de Santa Maria em 2014. Especialista em Educação Especial, Métodos e Técnicas de Ensino em Comunicação e Arte, Alfabetização, Educação de Jovens e Adultos, Educação Inclusiva - Sala de Recursos Multifuncional, Literatura Iberos-Americanas Contemporâneas. Professora efetiva na Rede Estadual do Paraná e Municipal de Foz do Iguaçu.

E-mail: mariahelenacosta71@gmail.com

\section{Maria Nazare dos Prazeres Lopes}

Especialista em educação matemática e ciências anos iniciais, licenciada em pedagogia. E-mail: nazarelopes44@yahoo.com.br

\section{Marcely Barroso Sarges}

Graduanda do curso de pedagogia da Universidade Federal do Pará.

E-mail: marcelyvictor@gmail.com 


\section{Renata Lourinho da Silva}

Doutora em educação matemática, licenciada em pedagogia e matemática.

E-mail: renatalourinhodasilva@gmail.com

\section{Silvana Minduá Vidal Veríssimo}

É educadora intercultural formada na Licenciatura Intercultural Indígena do Sul da Mata Atlântica na Universidade Federal de Santa Catarina. Pertencente ao povo guarani, é professora da Escola Estadual Indígena Wera Tupã Poty Dja..

\section{Sandro Faccin Bortolazzo}

Doutor em Educação pela Universidade Federal do Rio Grande do Sul (UFRGS). Pós-Doutorado em Cultura Digital pelo Institute for Culture and Society / Western Sydney University (Austrália/AU). Professor Substituto do Instituto Federal do Rio Grande do Sul (IFRS), Campus Bento Gonçalves.

E-mail: sandrobortolazzo@hotmail.com

\section{Tainá Suppi Pinto}

Graduação em Saúde Coletiva pela Universidade Federal do Rio Grande do Sul (2021). ORCID: https://orcid.org/0000-0001-7841-5861

E-mail: tainasuppi@gmail.com

\section{Verena Cissa Barbosa de Castro Freitas}

Mestre em educação matemática, licenciada em física e matemática.

E-mail: cissa_222@hotmail.com

\section{Vinicius Barbosa Cannavô}

Mestre em Educação pela Universidade Federal do Rio Grande do Sul (2021). Graduação em Teologia pela Universidade La Salle (2016). ORCID: https://orcid. org/0000-0001-7030-0349

E-mail: viniciuscannavo13@gmail.com

\section{Valéria Peres Asnis}

Docente da Faculdade de Educação (FACED) da Universidade Federal de Uberlândia. Contato: valeria.asnis@ufu.br

\section{Vanessa Matos dos Santos}

Docente da Faculdade de Educação (FACED) da Universidade Federal de Uberlândia. Contato: vanessamatos@ufu.br 


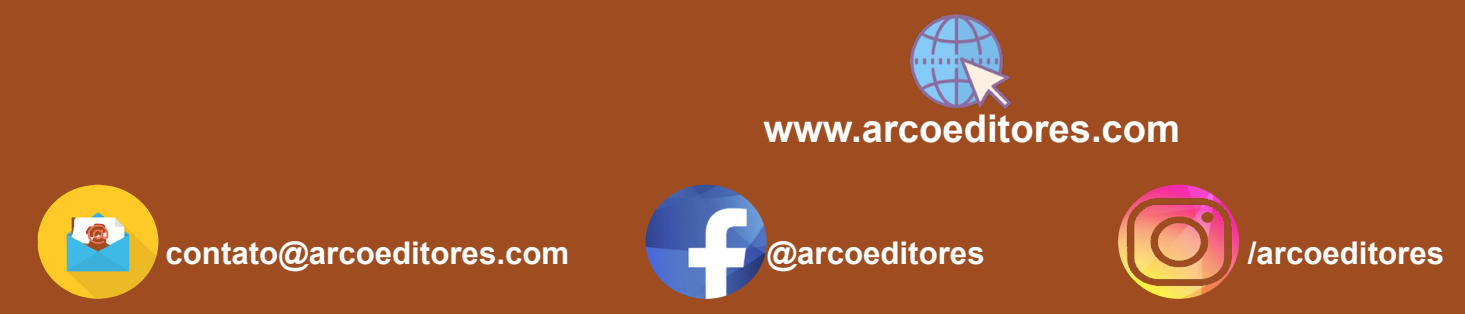

(55)99723-4952

\section{b)}

